
TORONTO PRESS 


$I$

$4^{53}$

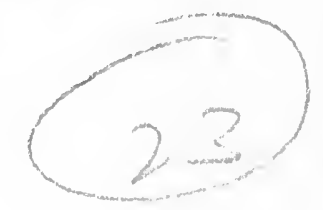

\section{RUNIC AND HEROIC POEMS}

OF THE OLD TEUTONIC PEOPLES 


\section{CAMBRIDGE UNIVERSITY PRESS}

C. F. CLAY, MANAGER

Ilondon: FETTER LANE, E.C. Eedinburgh: 100 PRINCES STREET

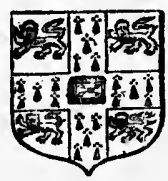

\{eto gork: G. P. PUTNAM'S SONS

bombay, Calcutta and ffladras: MACMILLAN AND CO., LTD. Euronto: J. M. DENT AND SONS, LTD. đoknga:? THE MARUZEN.KABUSHIKI-KAISHA 


\title{
RUNIC AND HEROIC POEMS
}

OF THE OLD TEUTONIC PEOPLES

\author{
edited by \\ BRUCE DICKINS \\ Allen Scholar
}

Sometime Scholar of Magdalene College

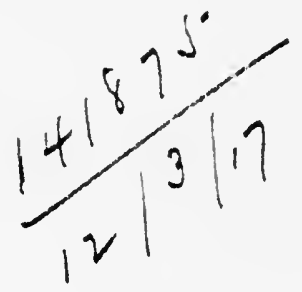

Cambridge :

at the University Press

I 9 I 5 
Cambridge:

PRINTED BY JOHN CLAY, MA
AT THE UNIVERSITY PRESS

TN

839

DD 


\section{PREFACE}

$T^{N}$ preparing this edition I have set before myself a 1 threefold aim; in the first place, to supply a sound, conservative text with all the necessary apparatus, prolegomena, translation, bibliography and notes both critical and exegetical; in the second, to make use of the archæological method which Professor Ridgeway has applied so brilliantly to the study of the Homeric poems; and in the third, to emphasise the essential unity of the old Teutonic languages in 'matter' as in poetic diction. How far it has been accomplished I cannot say: I can at least plead with Marryat's nurse in Mr Midshipman Easy that my book is 'such a little one.'

It cannot be claimed that the Runic poems are of any great literary value; they are exactly parallel, indeed, to the old nursery rhyme:

'A was an Archer who shot at a frog;
B was a Butcher who had a big dog.'

But they are of certain interest to the student of social history and of supreme importance in the early history of the English language, a fact most unfortunately neglected in two of the most recent and otherwise the best of English historical grammars.

The Anglo-Saxon poem last appeared in England in 1840 ; the Norwegian is only available in Vigfússon and 
Powell's Icelandic Prose Reader and Corpus Poeticum Boreale; the Icelandic has never before been published in this country.

The second part of this work contains the extant fragments of Anglo-Saxon heroic poetry outside Beowulf and Widsith, which have been so admirably treated by Dr Chambers (Cambridge, 1912 and 1914). Finn has, indeed, been edited by Dr Chambers as an appendix to Beowulf; but my notes were already complete when Beowulf appeared, and as I differ from him on various points-so much the worse for me in all probability-I have ventured to include it. It has been a labour of love: for Finn, mutilated and corrupt, is yet the fine flower of Anglo-Saxon heroic poetry. Full of rapid transitions and real poetic glow, the fight in Finn's beleaguered hall, lighted by the flash of swords and echoing with the din of combat, is one of the most vivid battle-pieces in any language-a theme too often worn threadbare by dull mechanical prentice-work in later Anglo-Saxon poetry, when versifying the scriptures became a devastating industry and the school of Cynewulf anticipated by some eight centuries the school of Boyd.

Waldhere has not been edited in English since the editio princeps of 1860, and Dr W. W. Lawrence's treatment of Deor is not very accessible in Volume IX. of the American journal Modern Philology.

The Old High German Hildebrand has never before been edited in English, and I must apologise to experts for my temerity. It is primarily intended for students of Anglo-Saxon and Old Norse; but it may, I hope, be useful to neophytes in German too.

It is now my pleasant duty to thank my many friends in Cambridge. I have received encouragement and help of the 
most substantial kind from the Master, President, Librarian and Fellows of my own College; from the Disney Professor of Archæology and the Schröder Professor of German; from Miss A. C. Paues, of Newnham College, Mr E. C. Quiggin, of Gonville and Caius College, and Mr E. H. Minns, of Pembroke College. My friends and fellow students, Miss N. Kershaw, of St Andrews, and Mr W. F. W. Mortlock, Scholar of Trinity College, have read part of the MS. From the staff of the University Library and of the University Press I have received unfailing courtesy, however much I have tested their patience. But most of all I have to thank Mr H. M. Chadwick, Bosworth and Elrington Professor of Anglo-Saxon, who has rescued me from countless pits which I had digged for myself. Anyone who has had the good fortune to work with him will appreciate my debt; no one else can estimate it. If this volume does anything to lighten the burdens which he has piled upon himself, I shall not feel that $I$ have toiled in vain.

B. D.

35 Brunswick Square, W.C.

October 15th, 1915. 


\section{ABBREVIATIONS}

Aarb. f. n. O. Aarbøger för nordisk Oldkyndighed og Historie. Kjøbenhavn, 1866-.

Anglia. Zeitschrift für englische Philologie. Halle, 1878-.

Archiv f.n. S. Herrigs Archiv für das Studium der neueren Sprachen und Literaturen. Braunschweig, 1846-.

Arkiv f. n. F. Arkiv för nordisk Filologi. Christiania, 1883-8; Lund, 1889-.

B. B. Bonner Beiträge zur Anglistik hrsg. v. M. Trautmann. Bonn, 1898-.

E. St. Englische Studien. Heilbronn, 1877-89; Leipzig, 1890-.

Germ. Germania, Vierteljahrsschrift für deutsche Altertumskunde. Stuttgart, 1856-8, Wien, 1859-1892.

M. G. H. Monnmenta Germaniae Historica edidit G.H. Pertz; Scriptorum Tomi xxIx. Hannoverae, 1826-.

M. L. N. Modern Language Notes. Baltimore, 1886-.

M. L. R. The Modern Language Review. Cambridge, 1906-.

Mod. Phil. Modern Philology. Chicago, 1903-.

P. B. B. Paul und Braunes Beiträge zur Geschichte der deutschen Sprache und Litteratur. Halle, 1874 .

P. G. (1), (2). Pauls Grundriss der Germanische Philologie. Strassburg, 1891-3, 1896-1909.

P. M. L. A. Publications of the Modern Language Association of America. Baltimore, 1889-.

Tidskrift. Tidskrift for Philologie og Pædagogik. Kjöbenharn, 1860-.

Z. f. d. A. Haupts Zeitschrift für deutsches Altertum. Leipzig, 1841-53, Berlin, 1856-.

Z. f. d. Ph. Zachers Zeitschrift für deutsche Philologie. Halle, 18691908 ; Stuttgart, 1909-. 


\section{CONTENTS}

THE RUNIC POEMS

PAGE

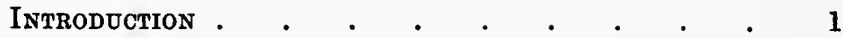

Biblography . . . . . . . . . 9

Text, Translation and Notes

The Anglo-Saxon Poem . . . . . 12

The Norwegian Poem . . . . . . . 24

The Icelandic Poem . . . . . . 28

Appendix: the Abecedarium Nordmannicum • . 34

THE HEROIC POEMS

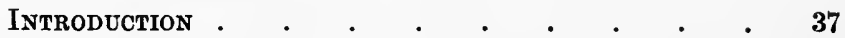

Bibliography . . . . . . . . . 50

Text, Translation and Notes

The Anglo-Saxon Waldhere . . . . . 56

The Anglo-Saxon Finn . . . . . . 64

The Anglo-Saxon Deor . . . . . . 70

The Old High German Hildebrand . . . 78

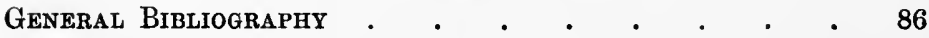

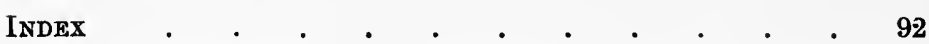

The Runic Alphabet figured.$\quad$. . . . . $\quad$. 


\section{THE RUNIC ALPHABET}

1. From the earliest inscriptions:

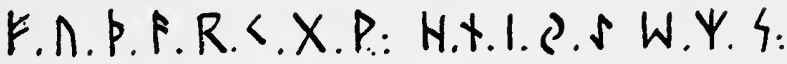

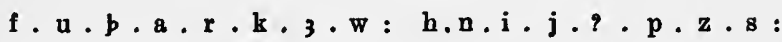

$$
\begin{aligned}
& \text { 个.B.M.M.T. ล. A. \&. } \\
& \text { t. b.e.m.1.ng.a.o. }
\end{aligned}
$$

2. Anglo-Saxon. (a) Runic Poem. (b) Salzburg Codex.

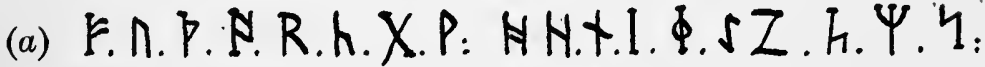
(b) Y.A.E.S.R.K.X.P: N.A.I. S . S.Y. Y: f. a.p.o.r.c.3.w: h.n.i.j.i,h,$p \cdot z \cdot s$.

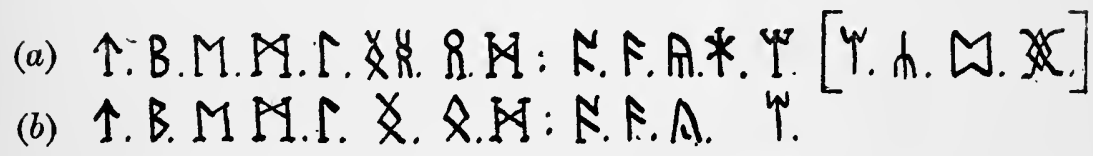

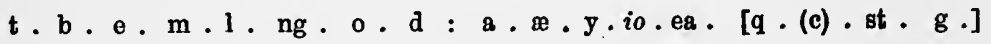

3. Scandinavian. (a) Jællinge Stone. (b) Runic Poems.

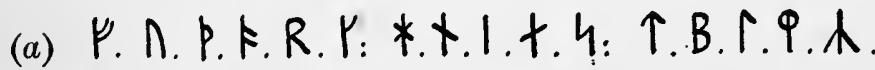

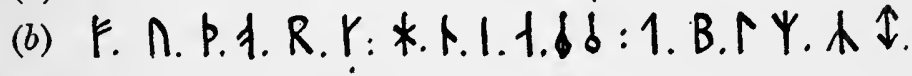
f. u, p.a. r,k:h,n,i,a,s:t,b,l,m,-r . 


\section{THE RUNIC POEMS}

Building the Runic rhyme, thy fancy roves

SOUTHEY 


\section{INTRODUCTION}

\section{THE RUNIC ALPHABET}

The origin of the Runic alphabet, the native script of the Teutonic peoples, is still a matter of dispute. Isaac Taylor derived it from a Thracian Greek alphabet, Wimmer of Copenhagen from the Latin alphabet; but each of these theories is open to grave objections, and it is perhaps less dangerous to conclude with von Friesen of Upsala that it was taken from a mixture of the two. It is sufficient here to mention that it must have been known to all the Teutonic peoples and that the earliest records go back at least to the fourth century. It was certainly known by the Goths before their conversion; for Wulfila took several of its characters for his Gothic alphabet, and two inscriptions (Pietroassa in Wallachia and Kovel in Volhynia) have been found in lands occupied by the Goths in this period.

In its original form the Runic alphabet consisted of 24 letters, which from the absence of curved or horizontal lines were especially adapted for carving on wood. Testimony is borne by Venantius Fortunatus, whose lines

\section{Barbara fraxineis pingatur runa tabellis \\ Quodque papyrus agit, virgula plana valet}

contain the earliest literary reference to the Runic character; by the Icelandic sagas and by the Anglo-Saxon poem known as the Husband's Message; but from the nature of the case the lance-shaft from Kragehul (Fyn) is almost a solitary

D. R. P. 
survivor of such inscriptions. The alphabet was divided into three sets later styled in Icelandic Freys rett, Hagals

$\checkmark$ ztt, Ty's $x t t$, from their initial letters F, H, T. These names were understood as "Frey's family," etc.; but tripartite division certainly goes back to the original alphabet-it is found on the sixth century bracteate from Vadstena, Sweden-and it is more probable that ztt is derived from atta, "eight," and so originally meant I "octave." Each letter, moreover, occupied a definite position; for in Codex Sangallensis 270 are to be found several varieties of Runic cypher-Isruna, Lagoruna, Hahalruna, Stofruna-the solution of which demands a knowledge of the exact position of each letter in the alphabet. Thus in the Latin Corui, the example given, the sixth letter of the first series is $\mathrm{C}$, the eighth of the third $\mathrm{O}$, the fifth of the first $R$, the second of the first $U$, the third of the second $\mathrm{I}^{1}$. A cypher similar in type to the Hahalruna of the St Gall MS., but adapted to the Scandinavian alphabet of the Viking Age, is to be found in the grave-chamber at Maeshowe (Orkney), and there are traces of similar characters, now for the most part illegible, in Hackness Church near Scarborough.

Among the earliest inscriptions from the North of Europe are those found in the bog-deposits of Nydam and Torsbjærg in Slesvig, $\mathrm{Vi}$ and Kragehul in Fyn, etc., which range in date from the third or fourth to the sixth century. They are written in a language which may be regarded as the common ancestor of English and Scandinavian; it still preserves the full inflections and is thus more primitive than the Gothic of Wulfila. The contemporary inscription from the Golden Horn of Gallehus (Jutland) may be quoted as an illustration, Ek Hlewazastiz Holtingaz horna tawido. (I Hlewagastiz Holtingaz made the horn.)

1 These cryptograms are possibly to be attributed to Hrabanus Maurus, Abbot of Fulda (822-856), who is known to have been interested in the Runic alphabet; ef. the Abecedarium Nordmannicum, p. 34 and his treatise De Inventione Linguarum (Migne cxir. 1582). Coruus is the Latin equivalent of Hraban (ON. Hrafn) and medieval scholars were fond of Latinizing their Teutonic names, e.g. Hrotsvith (Clamor validus), Aldhelm (Vetus galea). 
To the same period belong a brooch found at Charnay in Burgundy, and probably also an inscribed spear-head from Müncheberg (Brandenburg), together with two or three smaller objects found in the north of Germany. In Germany, however, inscriptions of this character are quite rare and mostly unintelligible, the latest belonging probably to the eighth century.

There can be no reasonable doubt that the alphabet was introduced into England by the Saxon invaders in the fifth century, though the inscriptions dating from the first two centuries after the invasion are very few and fragmentary. Among them we may especially note those ou a gold coin of unknown provenance in imitation of a solidus of Honorius and a scabbard-mount from Chessell Down in Wight. These are connected by the forms of the letters with inscribed objects from Kragehul and Lindholm (Skåne), which date in all probability from the early part of the sixth century, though the English inscriptions may be somewhat later. Runic legends also occur on a number of silver coins, some of then bearing the names $A$ Eill $(i) r r d$ (doubtless the Mercian king Aethelred, 675-704), or Pada, identified by some with Peada, brother of Aethelred, by others, and more probably, with his father Penda (d. 655). Runes are also found on a number of other small objects of metal or bone, the most interesting of which is the Franks Casket, generally believed to date from about 700 .

The gradual disuse of the Runic alphabet is well illustrated by coins of the eighth and ninth centuries. The last king whose name appears in Runic characters is Beonna of East Anglia (c. 750), and even on this coin a Roman O is found. On coins of subsequent kings we only meet with an occasional Runic letter, usually L. In the names of moneyers, however, the Runic letters seem to have persisted somewhat longer; for there are a number of coins issued by Eanred of Northumbria (809-841 ?), on which two of his moneyers signed their names in Runic characters.

Of memorial stones there are in existence nearly a 
score (principally in the North of England) bearing inscriptions in the English Runic character. The most notable of these are the elaborately carved crosses at Ruthwell (Dumfries) - with verses abridged from the Dream of the Cross-and Bewcastle (Cumberland), the grave slab with inscriptions both in Roman uncials and Runic characters from Falstone (Northumberland), and the three stones from Thornhill (Yorks.). Cf. Thornhill III. Gilsuip arærde æxter Berhtsuipe becun on bergi. Gebiddap pær saule. (Gilswith erected to the memory of Berhtswith a monument on the tomb. Pray for her soul.) The earliest date probably from the seventh century; while the latest contain forms which point to about the middle of the ninth. There seems no reason, however, for supposing that for this purpose the English Runic alphabet remained longer in use than for coins. At all events there is no evidence that it survived the great Danish invasion of 866 , which swept away the upper classes in the greater part of Northern England. After this time we find only MS. Runic alphabets, doubtless preserved as antiquarian curiosities, except for the letters wyn and porn, which had been adopted into the Anglo-Saxon book-hand, and eðel, dxg and man, which were occasionally used as shorthand in the MSs.

From the sixth century, however, the alphabet had developed on totally different lines in Scandinavia and England. To the original 24 letters the English eventually added six, $x s c, a c, y r$, ear, calc, gar, if not a seventh ior. The Scandinavian alphabet, on the other hand, continually reduced the number of letters, until by the ninth century no more than sixteen were left. How incapable they were of representing the sounds of the language can be seen from the greater Jællinge stone set up by Harold Bluetooth, king of Denmark (c. 940-986):

Haraltr kunukR bap kaurua kubl bansi aft Kurm fabur sin auk aft baurui mubur sina, sa Haraltr ias sạ uan Tanmaurk ala auk Nuruiak auk Tani karba kristna.

(King Harold ordered this monument to be made to the 
memory of Gorm his father and Thyre his mother, that Harold who conquered all Denmark and Norway and christianised the Danes.)

From the beginning of the eleventh century, however, the alphabet was supplemented by the so-called "dotted runes" (stunginn $k, i, t, b=g, e, d, p$ ).

The later Runic alphabet was known in Denmark, Sweden, Norway, Iceland, Greenland, the Faroes, the Orkneys, Man and England, in every part of the Scandinavian world; even in the South of Russia an inscription has been found. In Denmark there are something less than 200 inscriptions, few of which are later than 1150; in Sweden there are nearer 2000, some of which can scarcely be earlier than the fifteenth century. Scandinavian also in language and in character are the inscriptions from the Orkneys and Man. In England, too, there are a few relics of the Danish conquest, such as the sculptured stone in the library at St Paul's (c. 1030) and the porfastr comb from Lincoln in the British Museum.

In Norway and Iceland, however, the Runic alphabet is never found on monumental stones of the Viking Age, though it was used commonly enough for other purposes. The later Norwegian inscriptions date from the period 1050-1350, the Icelandic are not earlier than the thirteenth century. Generally speaking we may say that the Runic alphabet, always connected more or less with magical practices, fell under the suspicion of witchcraft in the Scandinavian countries and perished in the great outburst of superstitious terror which followed the establishment of the reformed religion, though there is some little evidence to show that in Sweden it lingered on into the nineteenth century ${ }^{2}$.

1 The Bridekirk font (Cumberland) bears a twelfth century English inscription in the Scandinavian Runic characters of that time with a few additional letters borrowed from the Anglo-Saxon book-hand.

2 There is not much evidence for the magic use of runes in this country. Bede (H.E. Iv. 22) tells the story of a Northumbrian noble captive to the Mercians at the battle of the Trent (679), whose chains were mysteriously loosened, whenever his brother, who thought him dead, celebrated masses for the repose of his soul. His gaoler in ignorance asked him whether he had 


\section{The Anglo-Saxon Runic Poem.}

The Anglo-Saxon Runic Poem is taken from the Cottonian MS. Otho $\mathrm{B} x$, which perished in the fire of 1731 . It had, however, been printed by Hickes in his Linguarum Veterum Septentrionalium Thesaurus, 1. 135 (London, 1705), from which the present text is derived. It consists of short stanzas, 29 in all, of two to five lines each, at the beginning of which stand the Runic characters described, preceded by their equivalents in ordinary script and followed by their names. It has been suggested, however, that in Otho $\mathrm{B} \mathrm{x}$, as in the Norwegian poems, the Runic characters alone were found, the names being added from some other MSs. At any rate Hempl, Mod. Phil. I. 135 ff., has shown that the variant runes, etc., were taken from Domitian A IX, and some such theory is needed to account for the frequent discrepancy between the stanzas and the names which they describe. This may be due in part to the lateness of the MS., which from linguistic criteria can scarcely have been earlier than the eleventh century, e.g. v. 37, underwrepyd for -od (-ed), and vv. 32, 91, ఫon, ఫonn for Ðonne. The poem must, however, be far earlier, pre-Alfredian at least (with traces perhaps of an original from which the Scandinavian poems are likewise derived); for there is not a single occurrence of the definite article, Jone in v. 70 being demonstrative. The versification is moreover quite correct. Cf. Brandl, Grundriss der germanischen Philologie ${ }_{2}$, II. 964.

\section{The Norwegian Runic Poem.}

The Norwegian Runic poem was first printed (in Runic characters) by Olaus Wormius, Danica Literatura Antiquissima, p. 105 (Amsterodamiae, 1636), from a law MS. in

litteras solutorias, de qualibus fabulae ferunt, concealed about his person. These litterae solutoriae are doubtless to be compared with Hávamál, CL :

$$
\begin{aligned}
& \text { bat kannk et fjorba ef mér fyrbar bera } \\
& \text { bond at boglimum } \\
& \text { Sva ek gel at ek ganga má } \\
& \text { sprettr af fọtum fjoturr } \\
& \text { en af hondum hafi. }
\end{aligned}
$$


the University Library at Copenhagen, which perished in the fire of 1728. This version was used by Vigfússon and Powell in their Icelandic Prose Reader (Oxford, 1879) and Corpus Poeticum Boreale (Oxford, 1883), where the textual difficulties are dealt with in a very arbitrary fashion.

The MSs. had, however, been copied later in the seventeenth century by Arni Magnússon and Jón Eggertson, whose transcripts, far more accurate than Worm's, exist at Copenhagen and Stockholm. It was on these that Kålund based his text in the first critical edition, Smastykker (København, 1884-91), pp. 1 ff., 100 ff., in which are incorporated valuable suggestions by Sophus Bugge and B. M. Olsen. Kalund added the names of the Runic letters, but printed the texts in their original orthography. In this edition, however, it has been thought more satisfactory to adopt the normalised Old Norwegian spelling used in the German translation of Wimmer's great work, Die Runenschrift, pp. 273-80 (Berlin, 1887).

The poem, which has certain affinities to the AngloSaxon, is ascribed to a Norwegian author of the end of the thirteenth century; ræi be impossible with the Icelandic forms reit and hrossum. It is composed in six-syllabled couplets, each of which contains two semi-detached statements of a gnomic character; the first line, which has two alliterating words, is connected by end-rhyme (except in the case of 15) and enjambement with the second which has none.

\section{The Ichlandic Runic Poem.}

The Icelandic Runic Poem, which is supposed to date from the fifteenth century, is somewhat more elaborate than its Norwegian prototype. It consists of sixteen short stanzas dealing in succession with the letter names of the Scandinavian Runic alphabet. In each of these stanzas are contained three kenningar - the elaborate periphrases which bulked so large in the technique of the Icelandic skaldic poems. The first and second lines are connected by 
alliteration, the third has two alliterating syllables of its own.

The Icelandic Runic alphabet contained several more letters at this time; but only the sixteen current in the Viking Age are treated here. This is perhaps natural if the poem is derived from a much earlier original, though it does not seem that the later dotted $\mathrm{U}, \mathrm{K}, \mathrm{I}, \mathrm{T}, \mathrm{B}$, introduced to represent $\mathrm{O}, \mathrm{G}, \mathrm{E}, \mathrm{D}, \mathrm{P}$ (with the possible exception of $\mathrm{P}$, plastr), had names of their own. They were simply

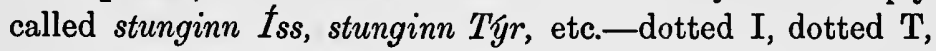
etc.

The poem is taken from four MSs. in the Arnamagnaean Library at Copenhagen.

1. AM. 687,4 to, parchment of the fifteenth century and containing the Runic characters, but not the names.

2. AM. $461,12 \mathrm{mo}$, parchment of the sixteenth century, with names only.

3. AM. 749,4 to, paper of the seventeenth century, with names and letters in alphabetical order, followed by "dotted runes."

4. AM. 413, folio, pp. 130-5, 140 ff., from parchments of the sixteenth century copied in Jón Ólafsson of Grunnavík's MS. Runologia (1732-52),

(a) with names and letters in alphabetical order,

(b) with names and letters in Runic order except that $l_{\ell} g r$ precedes madr.

Cf. Kålund, Småstykker, pp. 16 ff.; Wimmer, Die Runenschrift, pp. $281 \mathrm{ff}$. 


\section{Bibliography of the Runic Poems.}

The Runic Alphabet.

The extensive literature of the last thirty or forty years will be found noted in the Jahresbericht für germanische Philologie (Leipzig, 1879-1914); only the more important books and articles can be mentioned here.

Liljegren, J. G. Run-Lära. Stockholm. 1832.

Liliencron, R. von and Müllenhoff, K. Zur Runenlehre (Allgem. Monatsschrift, pp. 169 ff., 310 ff.). Kiel. 1852.

Stephens, G. The Old Northern Runic Monuments of Scandinavia and England. 4 vols. London and Kjøbenhavn. 1866-1901.

Handbook of the Old Northern Runic Monuments. L. \& K. 1884.

The Runes, whence came they? L. \& K. 1892.

Taylor, I. Greeks and Goths. London. 1879.

Burg, F. Die alteren nordischen Runeninschriften. Berlin. 1885.

Wimmer, L. F. W. Die Runenschrift. Berlin. 1887.

De tyske Runemindesmarker (Aarb. f. n. O. $1894 . \quad$ pp. 1 ff.).

Henning, R. Die deutschen Runendenkmäler. Strassburg. 1889.

Bugge, S. Norges Indskrifter med de aldre Runer. Christiania. 1891-1903.

Der Runenstein von Rök. Stockholm. 1910.

Runinskriftens Oprindelse. Christiania. 1905-1913.

Sievers, E. Runen und Runeninschriften (P.G., I. 238 ff.). Strassburg. 1891.

Friesen, O. von. On Runskriftens Hürkomst. Uppsala. 1904.

Paues, A. C. Runes and Manuscripts (Camb. Hist. Eng. Lit. I. 7 ff.). Cambridge. 1907.

Neckel, G. Zur Einführung in die Runenforschung (GermanischRomanische Monatsschrift, I. pp. 7 ff., 81 ff.). Heidelberg, 1909.

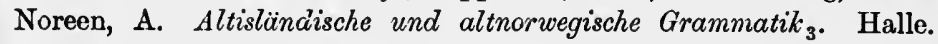
1903.

Liljegren, J. G. Run-Urkunde. Stockholm. 1833.

Thorsen, P. G. De danske Runemindesmoerker. 3 vols. Kjøbenhavn. 1864-1880.

Codex Runicus. Kjøbenhavn. 1877.

Wimmer, L. F. W. De danske Runemindesmcerker. 4 vols. Kjøbenhavn. 1895-1905.

do. haandudgave ved Lis Jakobsen. København. 1914.

Bugge, S. Norges Indskrifter med de yngre Runer. Christiania. $1902,1906$. 
Of the Swedish inscriptions now in course of publication by the Kongl. Vitterhets Historie och Antiquitets Akademi the following have appeared :

Söderborg, S. and Brate, E. Ölands Runinskrifter. Stockholm. 19001906.

Brate, E. Östergötlands Runinskrifter, I. Stockholm. 1911.

Kålund, K. Islands Fortidslovninger (Aarb. f. n. O. $1882 . \quad$ pp. 57 ff.).

Ólsen, B. M. Runerne $i$ den oldislandske Literatur. København. 1883.

Jónsson, F. Runerne $i$ den danske-islandske Digtning og Litteratur (Aarb. f. n. O. $1910 . \quad$ pp. $283 \mathrm{ff}$ ).

Farrer, J. Notice of Runic Inscriptions discovered during recent excavations in the Orkneys. Printed for private circulation. 1862.

Kermode, P. M. C. Manx Crosses. London. 1907.

Sweet, H. The Oldest English Texts. E.E.T.S. London. 1885.

Vietor, W. Die northumbrischen Runensteine. Marburg. 1898.

Chadwick, H. M. Early Inscriptions from the North of England (Yorkshire Dialect Society, Part III). Bradford. 1901.

Napier, A. S. The Franks Casket (Furnivall Misc., pp. 362 ff.). Oxford. 1901.

\section{The Anglo-Saxon Runic Poem.}

Hickes, G. Linguarum Veterum Septentrionalium Thesaurus, I. 135. London. 1705.

Grimm, W. K. Über deutsche Runen, pp. 217 ff. Göttingen. 1821.

Kemble, J. M. Archaeologia, xxvir. 339 ff. London. 1840.

Ettmüller, L. Engla and Seaxna scôpas and bôceras, pp. 268 ff. Quedlinburg. 1850.

Zacher, J. Das gotische Alphabet Vulfilas u. d. Runenalphabet. Leipzig, 1855.

Grein, C. W. M. Bibliothek der angelsächsischen Poesie, II. 354 ff. Cassel. 1858.

Gern. x. 428.

Rieger, M. Alt- und angelsächsisches Lesebuch, pp. 136 ff. Giessen. 1861.

Botkine, I. La Chanson des Runes. Havre. 1879.

Wülker, R. P. Kleinere ags. Dichtungen, pp. 37 ff. Halle. 1882.

Grein-Wülker. Bibliothek der ags. Poesie, r. 331 ff. Kassel. 1883.

Wiilker, R. P. Grundriss $z$. Geschichte $d$. ags. Litteratur. Leipzig. 1885.

Meyer, R. M. Die altgermanische Poesie, pp. 21 ff. Berlin. 1889.

Brooke, Stopford A. History of Early English Literature, I. $342 \mathrm{ff}$. London. 1892. 
v. Grienberger, Th. Die germanischen Runennamen (P.B.B., xxI. $185 \mathrm{ff}$.). Halle. 1896.

Die ags. Runenreihen (Arkiv f. n. F. xv. 1 ff.). Lund. 1899.

Chadwick, H. M. Anzeiger $f$. indogermanische Sprach- und Altertumskunde, IX. 60-63. Strassburg. 1898.

Kluge, F. Angelsächsisches Lesebuch $(3)$, pp. 152 ff. Halle. 1902.

Hempl, G. Hickes' additions to the Runic Poem. (Mod. Phil., I. 135 ff.) Chicago. 1903.

Mejer, R. M. Die altgermanische Runengedichte (P.B.B. xxxII. 67 ff.). Halle. 1907.

Brandl, A. Geschichte d. ae. Literatur (Paul's Grundriss d. germanischen Philologie (ed. 2), Ir. 964 ff.). Strassburg. 1908.

\section{The Scandinavian Runic Poems.}

O. Wormius. Danica Literatura Antiquissima, pp. 105 ff. Amsterodamiae. 1636.

W. K. Grimm. $\ddot{U} b e r$ deutsche Runen, pp. 246 ff. Göttingen. 1821.

P. A. Munch. Kortfattet Fremstilling af den nordiske Runenskrift, pp. $7 \mathrm{ff}$. Christiania. 1848.

G. Vigfússon and F. Y. Powell. Icelandic Prose Reader, pp. $440 \mathrm{ff}$. Oxford, 1879.

Corpus Poeticum Boreale, II. 369 ff. Oxford. 1883.

Kr. Kålund. Småstykker, pp. 1 ff., 100 ff. København. 1884-91.

L. F. A. Wimmer. Die Runenschrift, pp. 273 ff. Berlin. 1887.

F. Holthausen. Altisländisches Lesebuch, p. 93. Weimar. 1896. 


\section{THE ANGLO-SAXON RUNIC POEM}

I Feoh byp frofur fira gehwylcum;

sceal deah manna gehwylc miclun hyt dælan gif he wile for drihtne domes hleotan.

4 Ur byp anmod ond oferhyrned, felafrecne deor, feohtep mid hornum mære morstapa; bxt is modig wuht.

7 Đorn byp rearle scearp; бegna gehwylcum anfeng ys yfyl, ungemetum repe manna gehwylcum, ðe him mid resteð.

ı Os byp ordfruma ælcre spræce, wisdomes wrapu ond witena frofur
and eorla gehwam eadnys ond tohiht.

1. Feoh. Cf. AS. fech, Gothic fe from Salzburg Codex 140, a late copy of a Nortbumbrian text which there is some evidence for connecting with Alcuin. Cf. Chadwick, Studies in Old English (Camb. Phil. Soc. 1899, p. 117). Cf. Wimmer, die Runenschrift, p. 85.

4. Ur (Salz. AS. ur, Goth. uraz). Cf. ON. úrr, OHG. urohso; bos taurus primigenius, the aurochs or buffalo, the gigantic wild ox described by Caesar, B.G. vr. 28, as inhabiting the Hercynian forest :

Tertium est genus eorum qui uri appellantur. Hi sunt magnitudine paulo infra elephantos, specie et colore et figura tauri. Magna vis eorum est et magna velocitas, neque homini neque ferae quam conspexerunt parcunt.... Amplitudo cornuum et figura et species multum a nostrorum boum differt.

It is to be distinguished from the bison (e.g. Seneca, Phaedra, v. 68;

Tibi dant variae pectora tigres,

Tibi villosi terga bisontes,

Latibus feri cornibus uri,

and Pliny, Nat. Hist. vir. 15) with which it was confused in medieval Germany, cf. Albertus Magnus, De Animalibus, xxm. 2.

"Its remains occur abundantly in the later Plistocene deposits of Britain, those from the brick-earths of Ilford, in Essex, being remarkable for their fine state of preservation and showing the enormous dimensions attained by this magnificent animal " (Lydekker, Wild Oxen, p. 11, London, 1898). In Western Europe, however, it was still found in the Middle Ages; in the sixth century it was hunted in the Vosges (Gregory of Tours, $x .10$, Venantius Fortunatus, Misc. vir. 4. 19; cf. Nibelungenlied, str. 880), and doubtless in other thickly wooded regions, but was extinct by the end of the period. In Poland alone it persisted somewhat longer in the forest of Jakozowska (described and illustrated by von Herberstein, Rerum Moscovitarum Commentarii, Antwerp, 1557), where the last was killed in 1627. Cf. Lydekker, The $O x$ and its Kindred, pp. 37-67, pl. II. III. (London, 1912).

The borns of the aurochs, occasionally $6 \frac{1}{2}$ feet in length with a capacity of well nigh a gallon, were much prized as drinking vessels in medieval Europe, cf. Egilssaga, c. xurv. 3, Saxo, Bk vI. (Holder, p. 168); and the poet, who is scarcely likely to have seen an aurochs in the flesh, may have used one brought to England from the continent. 


\section{THE ANGLO-SAXON RUNIC POEM}

F. (wealth) is a comfort to all men; yet must every man bestow it freely, if he wish to gain honour in the sight of the Lord.

U. (the aurochs) is proud and has great horns; it is a very savage beast and fights with its horns; a great ranger of the moors, it is a creature of mettle.

p. (the thorn) is exceedingly sharp, an evil thing for any knight to touch, uncommonly severe on all who sit among them.

0. ( ? ) is the source of all language, a pillar of wisdom and a comfort to wise men, a blessing and a joy to every knight.

Hence oferhyrned, "with great horns," ofer being intensive as in vv. 29, 71, oferceald, oferleof.

7. born, so in all AS. Runic alphabets and in most of the OHG. derivatives (ci. v. Grienberger, $A r k . f . n . F . x v$. p. 1 ff.). $\quad b$ was adopted into the AS. book-hand and persisted throughout the ME. period, the last trace of it surviving in the archaistic ye (for the).

The Scandinavian alphabets, however, have purs (cf. AS. pyrs, a giant), and the Salzburg Codex Gothic thyth, which have no connection with each other or with AS. porn.

10. Os (Salzb.AS. os) <* ansuz, a god (cf. Jordanes, c. xurr., Gothi...proceres suos, quorum quasi fortuna vincebant, non puros homines, sed Ansis, id est semideos, vocaverunt, and the $\mathrm{ON}$. ass), the name of $\mathrm{A}$ in the original alphabet. Cf. $A(n)$ surisalas of the Kragehul lance-shaft. But original $a$ seldom remained in AS., and the character became the English Runic letter for $æ$ (æsc). Accordingly a lizature of $\mathrm{A}$ and $\mathrm{N}$ was invented to express the $\bar{o}$, which arose from -an-followed by $b$ or $s$. Later, when the name of the original $O$ letter had become $œ ð e l$, os was used for $o$ in all cases, whatever might have been their origin.

$O s$ is a common element in AS. personal names, e.g. Oswald, Oswine, etc.; cf. $A(n)$ suธisalas above, and its Gen. pl. esa used in the charm wid færstice (G.-W. I. 318)

gif hit wære esa gescot oððe hit wære ylfa gescot oððe hit wære hægtessan gescot, nu ic willan bin helpan.

Its precise meaning here is perhaps open to question, though the collocation zsir ok alfar is common in ON. mythological poetry.

In the Icelandic poem $\delta s s$, which likewise represents original *ansuz, = Othin, and it is just possible that this stanza refers to some such episode as that described in Gylfaginning, c. Ix.; pá er beir gengu með sævarströndu Borssynir (Óðinn; Vili and Vé), fundu peir tré tvau ok tóku upp tréin ok skqpuðu af menn; gaf inn fyrsti ond ok liff, annarr vit ok hraring, III asjonu, mál ok heyru ok sjón. But it is not very likely that the origin of human speech would be attributed to a heathen divinity, and on the whole it is preferable to assume that the subject of the stanza is the Latin 08 , mouth, which would be equally appropriate. 
13 Rad byp on recyde rinca gehwylcum sefte ond swiphwæt, бamðe sittep on ufan meare mægenheardum ofer milpapas.

16 Cen byp cwicera gehwam, blac ond beorhtlic, бær hi æpelingas

cup on fyre byrnep oftust inne restap.

19 Gyfu gumena byp gleng and herenys, wrapu and wyrpscype and wræcna gehwam ar and ætwist, ðe byp opra leas.

22 Wenne brucep, re can weana lyt

sares and sorge and him sylfa hæf blæd and blysse and eac byrga geniht.

25 Hægl byp hwitust corna; hwyrft hit of heofones lyfte, wealcap hit windes scura; weorpep hit to wætere syððаn.

27 Nyd byp nearu on breostan;

weorpep hi peah oft nipa bearnum

to helpe and to hæle gehwæpre, gif hi his hlystap æror.

29 Is byp oferceald, ungemetum slidor, glisnap glæshluttur gimmum gelicust, flor forste geworuht, fæger ansyne.

22. Hickes, wen ne.

31. geworulit.

13. Rad (Salz. AS. rada, Goth. reda), as in other alphabets. It is most satisfactory on the whole to take rad as "riding," cf. ræið, reið of the Norwegian and Icelandic poems.

"Riding seems an easy thing to every warrior while he is indoors, and a very courageous thing to him who traverses the high-roads on the back of a stout horse," though it is doubtful whether by $p$ can mean "seems," and neither hwæt nor any of its compounds are used of things.

Professor Chadwick has, however, suggested to me that the proper name of this letter is rada of the Salzburg Codex, corresponding to the ON. reiði, " tackle (of a ship)," "harness," hence "equipment" generally. Here it would be used in a double sense, in the first half as "furniturc" (cf. ON. reiðustól, "easy-chair," $\Lambda \mathrm{S}$. rædesceamu), in the second as "harness."

16. Cen (Salzburg AS. cen, Goth. chozma?) found only as the name of the Runic letter C. Cf. OHG. kien, kèn; pinus, fax, taeda, "resinous pinewood," hence "torch." Like the ON. K (kaun), it is descended from the $\mathrm{K}(<)$ of the earliest inscriptions. From the sixth century, at least, English and Scandinavian developed on independent lines, the point of divergence being marked by the lance-shaft from Kragehul (Fyn) and the snake from Lindholm (Skane), which has the same intermediate form of $K(\mathcal{N})$ as the earliest of English inscriptions, the SKANOMODU coin and the scabbard-mount from Chessell Down. But in AS. $c$ and $g$ became palatal before front vowels, and the original letters were used for this sound, new 
R. ( ? ) seems easy to every warrior while he is indoors and very courageous to him who traverses the highroads on the back of a stout horse.

C. (the torch) is known to every living man by its pale, bright flame; it always burns where princes sit within.

G. (generosity) brings credit and honour, which support one's dignity; it furnishes help and subsistence to all broken men who are devoid of aught else.

W. (bliss) he enjoys who knows not suffering, sorrow nor anxiety, and has prosperity and happiness and a good enough house.

H. (hail) is the whitest of grain; it is whirled from the vault of heaven and is tossed about by gusts of wind and then it melts into water.

N. (trouble) is oppressive to the heart; yet often it proves a source of help and salvation to the children of men, to everyone who heeds it betimes.

I. (ice) is very cold and immeasurably slippery; it glistens as clear as glass and most like to gems; it is a floor wrought by the frost, fair to look upon.

characters, calc and gar, being invented to express the gutteral sounds. These later characters do not occur on the Thames scramasax or in any of the few inscriptions from the South of England, so it may be inferred that they were peculiar to Northumbria.

calc does not actually occur in Hickes, but is taken from Domit. A. Ix. and Galba A. Ir. rosity."

19. Gyfu (Salzburg AS. geofu, Goth. geuua), gumena, abstract, "gene-

22. Hickes, Wen ne bruceð, ðe can weana lyt. Wenne, dat. sg. of wen, not wèn (cf. Dom. A. Ix.), a Kentish form of the wyn of the Salzburg Codex, Galba A. II. etc. (Sievers, Anglia, xrr. 4). As the name of the Runic W, woyn suits admirably in the passages of Cynewulf, e.g. Crist, v. 805, Elene, v. 1263, and is found elsewhere in AS. MSs., e.g. Elene, v. 1089, on wuldres $W$; Riddle xcr. $7, \bmod W$; Ps. Cos. xcIx. 1, Wsumia $b=j u b i l a t e$. From the Runic alphabet wyn, like porn, was adopted into AS. script.

25. Hægl (Salz. AS. haegil, Goth. haal). Cf. Hagall in the Norwegian and Icelandic poems. The first two Runic characters in Hickes are taken from Domit. A. Ix., the third alone belongs to the poem; ef. Hempl. Mod. Phil. x. 13.

26. wealcab hit windes scura; if scur can be fem. as Goth. skura (windis), ON. skur, scura, N. pl., may be retained; otherwise it must be emended to scuras.

27. Nyd (Salzb. AS. naed, Goth. noicz?). Cf. Scandinavian poems and Elene, จ. 1260: N gefera nearusorge dreah enge rune. 
32

Ger byp gumena hiht, ðonne God lætep, halig heofones cyning, hrusan syllan beorhte bleda beornum ond tearfum.

35 Eoh byb utan unsmepe treow, heard hrusan fæst, hyrde fyres, wyrtrumun underwrepyd, wyn on eple.

38 Peorð byp symble plega and hlehter wlancum [on middum], Jar wigan sittap on beorsele blipe ætsomne.

4I Eolh-secg eard hæf $p$ wexer on wature, wundap grimme, $/$ blode breneð beorna gehwylcne бе him ænigne onfeng gedep.

45 Sigel semannum symble bip on hihte, oonne hi hine feriap ofer fisces bep,
op hi brimhengest bringe $\vec{p}$ to lande.

32. H. ðon. 37. H. wynan on eple.

39. on middum supplied by Grein. 41. H. eolhx seccard.

32. Ger (Salz. OE. gaer, Goth. gaar) = summer.

Gear originally meant the warm part of the year (cf. Russian ярь, "spring-corn"), parallel to winter; this meaning is occasionally found in AS., e.g. Beowulf, v. 1134. Then both gear and winter were used for the whole year, though at a later time winter was restricted to its original significance.

In Scandinavian ar came to denote the "products of the summer," hence "plenty, abundance," e.g. til ars ok friðar, "for peace and plenty."

In the older alphabet the letter stood for $\mathrm{J}$; but the initial $j$, falling together with palatal $g$ in AS., is almost invariably represented by the $g y f u$ letter in inscriptions. Cf., however, v. 87, iar.

35. Eoh : except in Runic alphabets this word is written $i w$, se hearda iw of Riddle Ivv. 9; but cf. OHG. iha beside ixa. The original form may have been "ihwiz. Hickes gives the value as eo, doubtless taken from Domit. A. Ix. The value of the letter in the original alphabet is quite nnknown; but the Salzburg Codex has $i h$ with the values $i$ and $h$, and this agrees with the only intelligible inscriptions in England in which the letter occurs, viz. Dover: Gislheard (value $i$ ); Ruthwell: Almehttig (value $h$ ); Thornhill II : Eateinne for Eadpegne (value $i$ ).

Eoh survived as yogh, yok, etc., the name of the 3 letter in Middle English. Cf. A. C. Paues, M. L. R. vr. $441 \mathrm{ff}$.

38. Peorð (Salzb. AS. peord, Goth. pertra). P was a rare sound in the parent language. It is absent from the earliest Northern Inscriptions, and in the alphabet from the Vadstena bracteate is represented by $B$. The brooch from Charnay, Burgundy, has in this place a letter much resembling the modern W, and in England it is found only in Ms. lists of runio characters and on coins (e.g. Pada, Epa), never in inscriptions.

Peor $\gamma$ is never found save as the name of the letter $\mathrm{P}$, and no stress can be laid on any of the suggested meanings. Leo, As. Glossar. Halle, 1877, 
J. (summer) is a joy to men, when God, the holy King of Heaven, suffers the earth to bring forth shining fruits for rich and poor alike.

I. (the yew) is a tree with rough bark, hard and fast in the earth, supported by its roots, a guardian of flame and a joy upon an estate.

P. (the chessman?) is a source of recreation and amusement to the great, where warriors sit blithely together in the banqueting-hall.

Z. (the ?-sedge) is mostly to be found in a marsh; it grows in the water and makes a ghastly wound, covering with blood every warrior who touches it.

S. (the sun) is ever a joy to seafarers (or, in the hopes of seafarers) when they journey away over the fishes' bath, until the courser of the deep bears them land.

compares Slav. pizda=vulva, W. Grimm the Icelandic peð, "a pawn in chess." This latter suggestion is not regarded with much favour by H. J. R. Murray in his History of Chess, p. 420 (Oxford, 1913).

41. Hickes, Eolhx seccard hæfb oftust on fenne.

Grimm emends to eolugsecg eard, Grein to eolx secg eard and Rieger to eolh secg eard, "the elk-sedge (sumpfgras als lager oder nährung des elches) always grows in a marsh."

This letter, originally $z$ (which disappeared finally, and became $r$ elsewhere in AS.), is a fossil found only in Runic alphabets. An earlier form of the name is seen in Epinal-Erfurt, 781, papiluus : ilugsegg, ilugseg (cf. the ilcs of the Salzburg Codex), which cannot be connected with the word for elk, and Wright-Wülker, Voc. 286. 36, eolxsecg: papiluus, where papiluus probably = papyrus.

Cf. Epinal-Erfurt, 795, paperum, papirum : eorisc.

Corpus, 1503, papirum: eorisc (bulrush).

The subject of this stanza is therefore some rush, species unknown.

In this connection it is interesting to note that both secg and the Lat. gladiolus, which it glosses in E.E. 463, and Corpus, 977; are derived from words for sword ; cf. Skeat, Etymological Dictionary, p. 546 (Oxford, 1910).

43. Hickes, blode breneð.

The natural way would be to take it as "browns (stains) with blood" from brun; cf. Dante, Inferno xIII. 34, Da che fatto fu pot al sangue bruno; but no such verb occurs in AS. or ON. Brened (from beornan), "burns with blood," makes no sense. A better interpretation is suggested by a passage in Wulfstan, 183. 17 Drihtnes rod bid blode beurnen, "the cross of the Lord is covered with blood." Possibly we should emend to beernef (though this verb does not actually occur) rather than to beyrned.

45. Sigel (Salzb. AS. sygil, Goth. sugil) evidently " sun." Cf. Norwegian and Icelandic sól. Moreover in the Exeter Book it is found at the beginning and the end of Riddle vir., to which the answer is "the sun." Cf. Tupper, Riddles of the Exeter Book, p. 81, and Wyatt, Old English Riddles (frontispiece 2, 3).

46. hine, for heonan, hence, away ; cf. Bede's Death Song v. 1 Air his hiniongae. For the intrans. use of ferian, cf. Maldon, $\nabla .179$, etc.

D. R. P. 
48 Tir bip tacna sum, healdeð trywa wel wip æpelingas; ofer nihta genipu,

a bip on færylde næfre swicep.

5I Beorc byp bleda leas, berep efne swa бeah tanas butan tudder, bip on telgum wlitig, heah on helme hrysted fægere, geloden leafum, lyfte getenge.

55 Eh byp for eorlum æpelinga wyn, hors hofum wlanc, welege on wicgum and bip unstyllum forðam drihten wyle dome sine pæt earme flæsc eorpan betæcan.

63 Lagu byp leodum langsum gepuht, gif hi sculun nepan on nacan tealtum and hi sæypa swype bregap and se brimhengest bridles ne gym[eซ].

53. H. beah. 56. H. $y m b$. 59. H. $d e g$ inserted above man. 60. H. odrum. 64. H. nepun. 66. H. gym.

48. Tir (Salzb, AS. Ti. Goth. Tyz).

There can be no doubt that the original name of this letter was Ti (Tiv) from ${ }^{\star} T i w a z$, cf. ON. Týr, pl. tivvar. This word appears in glosses, e.g. Epinal-Erfurt, 663, Corpus, 1293, Mars, Martis: Tiig, and most of the Teutonic peoples use it as a translation of Martis, in the third day of the week. It is natural therefore to suppose that Tir is a misreading for Tiw. If tacna $8 u m=$ star, one would expect it to be the planet Mars $\delta$; but the description of the poem is appropriate rather to "a circumpolar constellation" (Botkine). Possibly the poet had in his mind a word different from A the original name of the letter.

Cf. ON. týri (?) : lumen (Egilsson, Lexicon Poet. s.v.). E.g. Leiðarvísan, v. 14, harri heims týriss ; "King of the light of the world."

51. Beorc (Salz. AS. berc, Goth. bercna; cf. ON. bjarkan). The customary meaning "birch" is here unsuitable; but according to the glossaries it can mean "poplar" too,

e.g. Epinal-Erfurt, 792, populus : birciae.

Corpus, 1609 , populus : birce.

Wright, Voc. 1. 33. 2, 80.13, byrc: populus.

Anecdota Oxon., 56, 364, 365, byric: populus, betula.

by $b$ bleda leas. Doubless popular science. Cf. Evelyn, Silva (London, 1908), 1. 128 : "I begin the second class with the poplar, of which there are several kinds; white, black, etc., which in Candy 'tis reported bears seeds." It is a fact, however, that poplars are almost always grown from slips or suckers. For instance, Mr H. J. Elwes declares that he has never found in England a poplar grown from seed either naturally or by nurserymen, that 
T. ( ? ) is a (guiding) star; well does it keep faith with princes; it is ever on its course over the mists of night and never fails.

B. (the poplar) bears no fruit; yet without seed it brings forth suckers, for it is generated from its leaves. Splendid are its branches and gloriously adorned its lofty crown which reaches to the skies.

E. (the horse) is a joy to princes in the presence of warriors, a steed in the pride of its hoofs, when rich men on horseback bandy words about it; and it is ever a source of comfort to the restless.

M. the joyous (man) is dear to his kinsmen; yet every man is doomed to fail his fellow, since the Lord by his decree will commit the vile carrion to the earth.

L. (the ocean) seems interminable to men, if they venture on the rolling bark and the waves of the sea terrify them and the courser of the deep heed not its bridle.

moreover nogood description orillustration of the germination of poplars seems to have been published in England before that of Miss F. Woolward in 1907; of. Elwes and Henry, The Trees of Great Britain and Ireland, vol. vir. pp. $1770 \mathrm{ff}$. (Edinburgh, 1913).

The grey poplar (populus canescens), indigenous to England and Western Europe, is a large tree attaining $100 \mathrm{ft}$ or more in height (lyfte getenge) and $15 \mathrm{ft}$ in girth.

55. Eh, as the Salzburg Codex. Cf. Gothic aihwatundi, Lat. equus, Greek $i \pi \pi$ os; value $\mathbf{E}$ in the original alphabet and in AS.

In Scandinavian, however, the word became jor and the letter dis. appeared, $E$ being represented by $I$. Later still a dotted I was introduced to differentiate between $\mathrm{E}$ and $\mathrm{I}$.

56. Hiokes $y m b$, emended to ymbe, metri gratia (Sievers, P.B.B., x. 519).

59. Man (Salzburg AS. mon, Goth. manna). Cf. p. 32, l. 1 (Icelandic poem), Mađr er manns gaman ok moldar auki.

Above the correct vulue $m$ Hickes engraves $d$. deg., doubtless taken from Domit. A. Ix. Cf. v. 74, Dxg.

The Runic character for $\mathrm{M}$ is used fairly often in the Lindisfarne Gospels and the Rituale of Durham, once too in the preface to the Rushworth Gospels, FarM for Farman (e.g. Surtees Society, Stevenson, Rituale Ecclesiae Dunelmensis, 1840; Stevenson and Waring, The Lindisfarne and Rushworth Gospels, 4 vols., 1854-1865). It is found moreover in the Exeter Book, e.g. Ruin, v. 24, Mdreama for mandreama.

63. Lagu, sea, ef. OS. lagu- in compounds, ON. lggr. (Salzburg Codex AS. lagu, Goth. laaz.)

The same meaning is found in the Runic passages of Cynewulf, Crist, v. 807, Elene, v. 1268, Fates of the Apostles, II. v. 7.

66. ne gym[eð]. Hickes, negym, the last two letters being doubtless illegible in the ms. 
67 Ing wæs ærest mid East-Denum

gesewen secgun, op he sirran est

ofer wæg gewat; wæn æfter ran;

ous Heardingas one hæle nemdun.

7 Epel byp oferleof æghwylcum men, gif he mot $r æ r$ rihtes and gerysena on brucan on bolde bleadum oftast.

74 Dæg byp drihtnes sond, mære metodes leoht, eadgum and earmum,

deore mannum, myrgb and tohiht eallum-brice.

flæsces fodor, ferep gelome
ofer ganotes bæp; garsecg fandap
hwæper ac hæbbe
æpele treowe.

73. H. blode。

74. H. mann inserted above dag.

67. Ing (Salzb. AS. Ing, Goth. Enguz), the letter for $n g$ in the original alphabet; occasionally it is used for ing, e.g. Birzngu on the stone from Opedal, Norway; Ing is doubtless the eponym of the Ingwine, a name applied to the Danes in Beowulf, vv. 1044, 1319, where Hrothgar is styled eodor Ingwina, frean Ingwina.

The earliest reference to Ing is to be found in the Ingaevones of Tacitus, c. II., and Pliny, whom Professor Chadwick (Origin of the English Nation, pp. $207 \mathrm{ff}$.) has shown there is some reason for identifying with the confederation of Baltic tribes who worshipped Nerthus, id est Terra Mater, on an island in the ocean, perhaps the Danish isle of Sjælland. But in later times the name is almost exclusively confined to Sweden; e.g. Arngrim Jónsson's epitome of the Skiöldunga saga (Olrik, Aarb.f.n. O., 1894, p. 105): tradunt Odinum...Daniam... Scioldo, Sveciam Ingoni filiis assignasse. Atque inde a Scioldo, quos hodie Danos, olim Skiolldunga fuisse appellatos; ut et Svecos ab Ingoni Inglinga. In Icelandic literature, e.g. the Ynglinga saga, the name Ynglingar is applied to the Swedish royal family, and the god Frey, their favourite divinity and reputed ancestor, is himself styled Yngvi-Frejr and Ingunar freyr (the lord of the prosperity of the Ingwine or the husband of Ingun). It is significant, moreover, that the name of his father Njor $\%$ r is phonetically equivalent to Nerthus, and his own cult as a god of peace and prosperity is evidently descended from that of the selfsame goddess (cf. Chadwick, O.E.N. p. 230 ff.).

69. wōn $x$ fter ran, doubtless to be connected with the following passages, Tacitus, Germania, c. xL: They have a common worship of Nerthus, that is Mother Earth, and believe that she intervenes in human affairs and visits the nations in her car, etc., and the story of Gunnarr Helmingr in the Flateyjarbok Saga of Olaf Tryggvason, which relates that there was in Sweden an image of the god Freyr, which in winter time was carried about the country in a car, gera monnum árbót, to bring about an abundant season for men; cf. Vigfússon and Unger, Flateyjarbók, 1. 338, translated in Sephton's Saga of $K$. Olaf Tryggvason, p. $258 \mathrm{ff}$.

7o. Heardingas, not elsewhere in AS., perhaps a generic term for "warriors" as in Elene, vv. 25, 130. It corresponds however to the ON. Haddingjar and the Asdingi, a section of the Vandals (from haddr, "a 
NG. (Ing) was first seen by men among the East-Danes, till, followed by his car, he departed eastwards over the waves. So the Heardingas named the hero.

CE. (an estate) is very dear to every man, if he can enjoy there in his house whatever is right and proper in constant prosperity.

D. (day), the glorious light of the Creator, is sent by the Lord; it is beloved of men, a source of hope and happiness to rich and poor, and of service to all.

A. (the oak) fattens the flesh (of swine) for the children of men. Often it traverses the gannet's bath, and the ocean proves whether the oak keeps faith in honourable fashion.

coiffure"; cf. Tacitus' account of the Suevi, Germ. c. xxxvirr.). The term skati Haddingja, "prince of the H.," is used in Kalfsvisa (Skaldskaparmál, c. LVIII.), and is applied to Helgi, the reincarnation of Helgi Hundingsbani, in the prose which follows Helgakvipa Hundingsbana II.

In two of the Fornaldar Sögur, Hrómundarsaga Greipssonar, c. vi., and Örvar-Oddssaga, c. xIv., Haddingi is a personal name; and in Saxo, Bk I. (Holder, p. 19 ff.), mention is made of a Hadingus, King of the Danes, whose visit to the nether world is probably alluded to in the phrase from Guprúnarkvipa hin forna, c. xxı1., lands Haddingja ax óskorit. It is worthy of note, moreover, that the verses (Gylf, c. xxirr.) in which Njor and Skaði bewail their incompatibility of temperament are by Saxo (Holder, p. 33) attributed to Hadingus and his wife. On the whole it seems most satisfactory to regard Heardingas as the name of a people or a dynasty, conceivably the North Suevi; for Saxo, at any rate, derives fictitious personages from national or dynastic names, cf. Hothbroddus, Bk II. (Holder, p. 52), and the Heaðobeardan of Beowulf, vv. $2032 \mathrm{ff}$.

71. Ebel (Salzburg AS. oedil, Goth. utal), originally perhaps *öbila, the name of the $O$ letter in the original alphabet. Cf. Golden Horn of Gallehus (Jutland), HORNA TAWI円O ; English coin from British Museum, SKANOMODU. In AS. it became apel (WS. epel) and the letter changed its value to $a$, e.g. Ruthwell Cross, LIMW $Q E$ RIGNÆ. This letter is occasionally found in AS. Mss. as a grammalogue for epel, e.g. Waldhere, v. 31, Beowulf, v. 520, 913, 1702.

74. Dæg (Salz. AS. daeg, Goth. daaz). Hickes, following the ignorant scribe of Dom. A. Ix., inserts $m$, mann, above the correct value $d$.

The Runie letter D is regularly found as a grammalogue for $d æ g$ in the Rituale of Durham, occasionally too in the Lindisfarne Gospels.

77. Ac (<*aik-), doubtless a ligature of $\mathrm{A}$ and $\mathrm{I}$, the first of the characters introduced to express the sound-changes which differentiated AS. from the language of the earliest Northern inscriptions.

elda bearnum flæsces fodor, acorns, as the food of swine, since pork was the flesh most commonly eaten in AS. times. For an illustration of swine feeding in an oak-forest, cf. AS. calendar for September, Cott. Tib. B. v., Jul. A. vi.

For the second part of the stanza, cf. Egill Skallagrimsson's Höfuðlausn, str. 1., "Drok eik á flot við isabrot" (Egilssaga, c. Ix.). 
81 Alsc bip oferheah, eldum dyre

stip on stapule, stede rihte hylt,

reah him feohtan on firas monige.

84 Yr byp æpelinga and eorla gehwæs

wyn and wyrbmynd, byp on wicge fæger, fæstlic on færelde, fyrdgeatewa sum.

87 Iar byp eafix and teah a bruces fodres on foldan, hafap fægerne eard wætre beworpen, бær he wynnum leofap.

90 Ear byp egle eorla gehwylcun, бonn[e] fæestlice flæsc onginnep, hraw colian, hrusan ceosan blac to gebeddan; bleda gedreosap, wynna gewitap, wera geswicap.

86. H. fyrdgeacewa. 87. H. eafixa. 88. H. onfaldan.

91. Jonn. At the end of Hickes' transcript there stand four runes to which no verses are attached, $c w, c w e o r \delta ; c[c a l c] ; s t, s t a n ; g, g a r$. Two of these Runic letters, calc and gar, are found on the Ruthwell Cross in the value of guttural $c$ and $g$.

81. AEsc, identical in form with A (*ansuz), the fourth letter of the older alphabet, since in the majority of cases original $a$ became $x$ in AS.

84. $\operatorname{Yr}$ (Salzb. yr). The Runic passages in Cynewulf give no assistance and the meaning is much disputed. The new edition of Grein's Sprachschatz translates "horn," I know not upon what evidence unless it be the parallel phraseology of Riddle xv. Others have identified it with the ON. yr, "bow," cf. p. 32 ; but this corresponds to AS. eoh, p. 16. Is it possible to connect AS. $y r$ with the word $x x e-y r e$ in the Chronicle $1012 \mathrm{E}$, translated by Plummer "axe-head," "axe-iron"? We might compare Ýr er...brotgjarnt jarn in the Icelandic poem, p. 32.

87. Hickes, Iar (io) bið ea fixa, and ðeah abruceb. Following Dom.A. Ix. and Galba A. II., W. Grimm emends to Ior.

As it stands eafixa is a Gen. pl. with nothing on which to depend, and the addition of sum (Grein) would render the verse unmetricsl. The final $a$ of eafixa should therefore be deleted (Rieger).

abrucep Grimm. a bruce $p$, "always enjoys."

This letter is not in the Salzburg Codex.

No such word as iar, ior exists; but the description here given is plainly that of some amphibious oreature, usually taken as the eel (Grimm), though it might equally well be a lizard or newt (aðexe, efete).

It is worth remarking that the letter is used in a number of Scandinavian inscriptions from the seventh century onwards, e.g. Bjorketorp, Stentofte, Gommor (Blekinge) and Vatn (Norway), seventh cent.; Kallerup, Snoldelev, Flemlöse (Denmark) and Örja (Skaane), early ninth cent., as a form of the letter $a r(a)$. The original value of this was $j$; moreover it occurs in two English inscriptions : Dover, GISLHÆิEARD ; Thornhill III, GILSUITH, with the value of palatal $g$, since palatal $g$ and original $j$ had fallen together at an early date in AS. 
A. (the ash) is exceedingly high and precious to men. With its sturdy trunk it offers a stubborn resistance, though attacked by many a man.

Y. ( ? ) is a source of joy and honour to every prince and knight; it looks well on a horse and is a reliable equipment for a journey.

IO. ( ? ) is a river fish and yet it always feeds on land; it has a fair abode encompassed by water, where it lives in happiness.

EA. (the grave?) is horrible to every knight, when the corpse quickly begins to cool and is laid in the bosom of the dark earth. Prosperity declines, happiness passes away and covenants are broken.

There appears to be no reason for doubting that this is a survival of the twelfth letter $(j)$ of the older alphabet. Is it possible then that iar (ior) is a corrupt form of the name gear? Cf. v. 32 (Chadwick). In that case we must of course assume that the poet had some other name in his mind, e.g. eel, newt.

90. Ear (Salzb. eor, value eo); this word is only found in Runic alphabets. Grein compares $\mathrm{ON}$. aurr, a poetical word which seems to mean loam or clay (cf. Vọluspá xIx. 2, Alvíssmál xIx. 4, Rígspala x. 3, Grottasongr xvr. 3), hence "ground " in the sense of "grave."

The letter is fairly common in inscriptions, e.g. Dover, GISLHEARD, Thames scramasax, BEAGNOTH, and often in Northumbria. In Northum. brian inscriptions it is used for eo as well as for ea, doubtless owing to the fact that these diphthongs were confused in Northumbria. 


\section{THE NORWEGIAN RUNIC POEM}

I Fé vældr frænda róge; fødesk ulfr i skóge.

2 Úr er af illu jarne; opt lфypr ræinn á hjarne.

3 purs vældr kvinna kvillu; kátr værơr fár af illu.

4 Óss er flæstra færða for; en skalpr er sværða.

5 Ræi Reginn sló sværð̌t bæzta.

6 Kaun er barna bolvan; bol gơrver nán folvan.

7 Hagall er kaldastr korna;

Kristr skóp hæimenn forna.

1. Fé. The Runic characters for $F$ and $M$ are used in Icelandio mss. for fé and mađr ; ef. Jónsson, Oldnorske Litteraturs Historie ir. 254. frænda róge, a kenning for gold ; cf. rogi Niflunga, Bjarkamál, v. 19, etc.

fфðesk ulfr i skoge. Cf. Cott. Gnomic Verses, v. 11: wulf sceal on bearowe.

2. Úr. Cf. Jón Olafsson, Runologia (Add. 8 fol. p. 141): Sunnlendingar kalla smidiu uur, pat Nordlingar smidiu giall, "people in the $\mathbf{S}$. of Iceland call ur what the Northerners call slag, the refuse from a smith's furnace." This is supported by a passage in the páttr af Gull-Ásu-porłi, c. vi. (ed. Jónsson, xL. Islendinga pættir, p. 83, Reykjavík, 1904), Úrt jârn, kvað kerlingr, ok atti kneif deigan. [Småstykker, p. 100, cf. pp. 106, 112.]

a. purs. As against the AS. porn (found twice in the grammatical treatises attached to the Prose Edda, Edda Snorra Sturlusonar II. 38, 365), all Scandinavian Runic alphabets have purs, the first element in such personal names as the Gothic Thorismund and the Gepide Thurisind; the earliest form of this word is the thuris of Hrabanus Maurus' Abecedarium Nordmannicum, see p. 34.

kvinna kvillu, kvilla =kvilli, sickness, ailment, freq. in mod. nsage (Cleasby-Vigfússon). In their Corpus Poeticum Boreale II. 370, Vigfússon and Powell translate the phrase "hysteries," perhaps on the strength of Skírnismál xxxvil. :

$$
\begin{aligned}
& \text { burs ristk pér ok pria stafi: } \\
& \text { ergi ok \&bi ok opola; } \\
& \text { svá af ristk sem bat á reistk, } \\
& \text { ef gorvask parfar bess. }
\end{aligned}
$$

4. Óss, orig. $<{ }^{*} A n s u z$, like the AS. os, perhaps perverted from its original significance by ecclesiastical influence in Norway as in England.

The text requires some emendation; Worm's Oys er flestra ferda, En skalpur er sverda has obviously lost a syllable; and Magnússon's Oss er læid flestra færda, En skalper er sværda, though translateable, is unmetrical. 


\section{THE NORWEGIAN RUNIC POEM}

I Wealth is a source of discord among kinsmen; the wolf lives in the forest.

2 Dross comes from bad iron; the reindeer often races over the frozen snow.

3 Giant causes anguish to women; misfortune makes few men cheerful.

4 Estuary is the way of most journeys; but a scabbard is of swords.

5 Riding is said to be the worst thing for horses; Reginn forged the finest sword.

6 Ulcer is fatal to children; death makes a corpse pale.

7 Hail is the coldest of grain;

Christ created the world of old.

Kålund, therefore, substitutes for læid the synonym for (so AM. 739 4to, a Ms. collection of Edda excerpts, in which Worm's version of the poem is preserved), and places it at the beginning of the second line. Bugge and Ólsen, however, regarding $f g r$, a short syllable, as metrically doubtful, suggest færill, yet a third synonym. [Smastykker, p. 101.]

5. Ræið. Cf. AS. poem, v. $13 \mathrm{ff}$.

Reginn, sou of Hreixmarr, who received the "Otter-price" from the Aesir, and brother of the serpent Fáfnir, who brooded over the gold on Gnita-heath. He fostered Sigurd, forged for him the sword Gramr and persuaded him to slay the dragon, but was slain by Sigurd, who suspected treachery. Cf. Reginsmál, Fáfnismál, Skaldsk. cc. xxxix.-xu. and Vọlsunga saga cc. xII1.-xIx., sværðet bæzta ; cf. Skaldsk. c. XL. : pa gQrði Reginn sverð bat er Gramr heitir, er svá var hvast at Sigurðr brá niðr i rennanda vatn, ok tók i sundr ullarlagð, er rak fyrir strauminum at sverðseggini. boi næst klauf Sigurðr steðja Regins ofan î stokkinn með sverðinu.

6. AM, JE, Kaun er beggja barna bol gorvir naan folfvan,

which Bugge would retain, "An ulcer is fatal to children of both sexes; it makes a corpse pale." Olsen, comparing kaun er barna böl of the Icelandic poem, and Landnámabók (Isl. I. 1526) böl gjörir mik fölvan, would emend to
Kaun er barna bQlvan; bol gorver man folvan.
"An ulcer is fatal to children; death makes a man pale."

[Smaistykker, p. 101.] But while accepting the emendation of the first line, I do not think it necessary to alter the ms. reading of the second.

7. kaldastr korna. Cf. AS. poem, v. 25, Hægl byp hwitust corna, and Seafarer, v. 32, hægl feol on eorðan, corna caldast.

Kristr. Christ was sometimes regarded as the Creator. Cf. Skaldsk. c. LI.: Hvernig skal Krist kalla? Svá at kalla hann skapara himins ok jarðar, etc. 
8 Naưr gerer næppa koste; ngktan kælr 1 froste.

9 Ís kqllum brú bræiða; blindan parf at læiða.

Io Ár er gumıa góðe; get ek at qrr var Fróbe.

I Sól er landa ljóme; lúti ek helgum dóme.

12 Týr er æinendr ása; opt værơr smiðr blása.

13 Bjarkan er laufgrǿnstr líma; Loki bar flærða tíma.

14 Maðr er moldar auki; mikil er græip á hauki.

15 Lggr er, fællr ór fjalle foss; en gull ero nosser.

16 Ýr er vetrgrø̊nstr við̄a; vænt er, er brennr, at sviða.

8. Nauðr. For use of the letter in magic, cf. Sigrdrifumál vir. :

Ölrunar skalt kunna ef bu vill annars kvǽn vélit bik $i$ trygh, ef trüir;

$a$ horni skalt rista ok á handa baki ok merkja a nagli Naup.

9. Is kgllum brü bræiða. Cf. Exeter Gnomic Verses, v. 72 ff. :

and Andreas, v. $1260 \mathrm{fi}$.

Forst sceal freosan...is brycgian, wæterhelm wegan,

10. $A r$, descended, like the AS. gear, from the old $j$ letter (" $j a \bar{r} r a)$. It means (1) year, (2) summer, ef. gear in Beowulf, v. 1136, (3) what summer brings, harvest, (4) prosperity, especially in the phrase til árs ok friðar, for peace and prosperity.

Fróðe, Friðleifsson (Frotho III of Saxo, Bk v.), the peace-king of Danish legend who is made a contemporary of Augustus. So great was the security in his days that a gold ring lay out for many years on Jællinge Heath. Fróxi owned the quern Grotti, which ground for him gold or whatsoever else he wished; hence gold is called by the skaldic poets Froða mjöl, "Froði's meal." Cf. Skaldsk. c. xuir.; Skjöldunga saga c. 111. [Chadwick, Origin of the English Nation, p. $257 \mathrm{ff}$.]

12. Týr, originally "the god," cf. Lat. divus; the pl. Tivar is used as a generic name for the gods in the Older Edda. In the Prose Edda (Gylf c. $X \times \nabla$.$) he is the god of war, but most of his functions have been usurped$ by 0 thin and he is a character of small importance in Scandinavian religion as it has come down to us. 
8 Constraint gives scant choice;

a naked man is chilled by the frost.

9 Ice we call the broad bridge; the blind man must be led.

10 Plenty is a boon to men; I say that Frothi was generous.

II Sun is the light of the world;

I bow to the divine decree.

I2 Tyr is a one-handed god; often has the smith to blow.

13 Birch has the greenest leaves of any shrub; Loki was fortunate in his deceit.

14 Man is an augmentation of the dust; great is the claw of the hawk.

15 A waterfall is a River which falls from a mountain-side; but ornaments are of gold.

16 Yew is the greenest of trees in winter; it is wont to crackle when it burns.

æinendr, because he offered his right hand as a pledge to the Fenrisulfr, who promptly bit it off when he found himself securely bound with the fetter Gleipnir (Gylf. c. xxxIv.). Cf. Sigrdrífumál vI. :

$$
\begin{gathered}
\text { Sigrinar skalt kunna, ef vill sigr hafa, } \\
\text { ok risti a hjalti hjors, } \\
\text { sumar â vêttrimum, sumar á valbostum } \\
\text { ok nefna tysvar Tý. }
\end{gathered}
$$

13. Bjarkan (=björk, birch), found only as the name of the letter B in the Runic alphabet.

Loki bar flærða tíma is not perhaps very satisfactory; it will translate, however, if bar tima be taken in the sense of bera $g x f u$ til, to be fortunate in; cf. Ólsen and Bugge, Smistykker, pp. 102,111. So it seems unnecessary to accept the C.P. B. emendation, Loki brá fiærða sima.

The reference is doubtless to Lokı's responsibility for Balder's death. Gylf. c. xurx.

14. Mađr er moldar auki. Cf. Hervarar saga c. v. 3 :

probably from Psalm cri. 14.

$$
\text { Mjök eruð orðnir Arngrims synir }
$$

15. Construe; foss er logr fællr or fjalle.

nosser. Icelandic hnossir.

16. It is worth noting that $y r$ is phonetically equivalent to the AS. eoh (ih), though the character which bears that name is apparently descended from the fifteenth letter of the old alphabet (eolh-secg), which in Scandinavian inscriptions from the sixth century onwards (e.g. Kragehul, Stentofte, etc.) is inverted. 


\section{THE ICELANDIC RUNIC POEM}

I Fé er frænda róg

ok flæðar viti

ok grafseios gata

aurum fylkir.

2 Úr er skýja grátr

ok skára pverrir

ok hirris hatr.

umbre vísi.

3 purs er kvenna kvöl

ok kletta búi

ok varðrúnar verr.

Saturnus pengill.

4 Óss er aldingautr

ok ásgaròs jofurr,

ok valhallar vísi.

Jupiter oddviti.

5 Reið er sitjandi sæla

ok snúxig feró

ok jórs erfið̄i.

iter ræsir.

6 Kaun er barna böl

ok bardaga [för]

ok holdfúa hús

flagella konungr.

1. fææðar viti, AM. 687 ; fyrða gaman, 461, 749, J0 b; Fofnis bani, JOa. Cf. porðar saga Hræða c. vi., viti leifnis lautar; ignis maris (Egilsson).

grafseiðs gata, lit. "path of the grave-fish" (seiðr: pisciculus, Egilsson), a kenning for gold from the connection of dragons and other serpents with graves containing treasure. Cf. Bjarkamál, จ. 19, Grafvitnis duinn ; Harmsól, v. 44, dælar seið's dunn.

aurum, etc. (from 687), more or less accurate equivalents in Latin of the letter names.

fylkir, etc. (from 687), a series of synonyms for "king," each of which alliterates with the stanza to which it is attached; with the exception of oddviti they are to be found in the bulor (rhymed glossaries) printed in C.P.B. II. $422 \mathrm{ff}$.

2. skýja grátr. Cf. Ragnars saga Loðbrókar, c. xxi. (FAS. I. 224), nu skýtr á mik skýja grátr. 


\section{THE ICELANDIC RUNIC POEM}

I Wealth $=$ source of discord among kinsmen

and fire of the sea

and path of the serpent.

2 Shower = lamentation of the clouds

and ruin of the hay-harvest

and abomination of the shepherd.

3 Giant = torture of women

and cliff-dweller

and husband of a giantess.

4 God = aged Gautr

and prince of Asgard

and lord of Valhalla.

5 Riding $=$ joy of the horseman

and speedy journey

and toil of the steed.

6 Ulcer $=$ disease fatal to children

and painful spot

and abode of mortification.

skara pverrir. Wimmer reads skara bverrir, "der eisränder auflöser," from skgr, "edge of the ice" ; but skâra (cf. Haldorsen, Lexicon IslandicoLatino-Danicum, Havniae 1814, skâri: circulus qui uno ictu falcis metitur, "swathe") is metrically preferable. (Smaistykker, p. 111.)

umbre, ooviously a mistake for imber. Cf. AM. 687, p. 3, Ymber skúr, skür er úr, ür er rünastafr (Wimmer, p. 287).

8. kletta búi. Cf. Hymiskvipa Ir. bergbúi, cliff-dweller, a common kenning for giant.

Varđrün, a giantess in the Nafnabulor, Snorra Edda, ed. Jonsson, p. 269. AM. 749 has si̊fförull seggr.

4. aldingautr, an epithet of Othin, the original meaning of which had probably been forgotten at the time of the poem's composition. Cf. Vegtamskvipa II., Upp reis Opinn aldinn gautr (according to Gering "redner," "sprecher"? "ancient suge"?). More probably Gautr is to be taken as "god of the Gautar" (the Geatas of Beowulf), cf. Grimnismál LIV., Guutr; Sonatorrek, v. 4: Hergautr; Valgautr, etc., an abbreviation of the Gauta. Týr found in Hákonarmál, v. 1.

Othin is always depicted as an old man.

For asgarð and valholl see the Prose Edda passim.

valhallar visi. Cf. Bugge, Småstykker, p. 112.

5. Reið. Cf. Rad in the Anglo-Saxon poem, p. 14.

jors, classical Icelandic $j \delta s$.

6. $687,461,749$, JO $a$, read bardagi alone, accepted by Wimmer. JO $b$, however, has bardaga för, which Bugge, Smaistykker, p. 111, takes in the sense of "et sted, hvor Plage (Smerte) færdes (holder til)." 
7 Hagall er kaldakorn

ok krapadrífa

ok snáka sótt

grando hildingr.

8 Naứ er pýjar prá

ok pungr kostr

ok vássamlig verk.

opera niflungr.

9 Iss er árbörkr

ok unnar pak

ok feigra manna fár

glacies jöfurr.

Io Ár er gumna gơði

ok gott sumar

ok algróinn akr

annus allvaldr.

I Sól er skýja skjöldr

ok skínandi röoull

ok isa aldrtregi

rota siklingr.

12 Týr er einhendr áss

ok ulfs leifar

ok hofa hilmir

Mars tiggi.

I3 Bjarkan er laufgat lim

ok lítit tré

ok ungsamligr vior

abies bưlungr.

7. snáka sótt, sickness of serpents, a kenning for winter. Cf. nað̆ra dey $ォ i$ in Ivarr Ingimundarson, C.P. B. 1 . 264.

8. Cf. Grottasongr, especially strophe xvI. :

$$
\begin{aligned}
& \text { Nu erum komnar til konungs húsa } \\
& \text { miskunnlausar ok at mani hafbar; } \\
& \text { aurr etr iljar, en ofan kulpi, } \\
& \text { drogum dolgs sjotul; daprt's at Frópar. }
\end{aligned}
$$

prá, aegritudo animi, maeror (Haldorsen).

pungr kostr, 749, JO. pvera erfiði, 461, illegible in 687 .

9. árbörkr, illegible in 687 . 
7 Hail $=$ cold grain

and shower of sleet

and sickness of serpents.

8 Constraint $=$ grief of the bond-maid

and state of oppression

and toilsome work.

9 Ice $=$ bark of rivers

and roof of the wave

and destruction of the doomed.

ro Plenty $=$ boon to men

and good summer

and thriving crops.

II $\operatorname{Sun}=$ shield of the clouds

and shining ray

and destroyer of ice.

12 Tyr = god with one hand

and leavings of the wolf

and prince of temples.

13 Birch = leafy twig

and little tree

and fresh young shrub.

unnar pak, 461, 749, JO $b$ : doubtful in 687; unnar bekja, JO $a$. Cf. Grettis saga, c. LII., $\bar{i}$ marbaks miðjum firð $i$ (in the midst of Isafjörðr, Icefirth).

feigra manna fâr, 687; feigs fär, JO $a$; feigs manns forað, 461; feigs forað, 749, JO $b$; cf. Fáfnismál IV., alt er feigs forað. With the use of this phrase as a kenning for "ice," cf. Málsháttakvæði, v. 25, sjaldan hittisk feigs vǫk frфrin (Wimmer).

10. gott sumar, 749, JO $a$; doubtful in 687 ; glatt $8 .$, JO b.

algróinn akr, 749, JO; ok vel flest pat er vill, 461; 687 has dala (doubtful) dreyri, "moisture of the dales," i.e. ár, N. pl. of a, "river" (Wimmer).

11. skýja skjöldr. Cf. pórsdrápa, v. 13, himintarga (C.P. B. II. 19). 749 and JO have, in place of isa aldrtregi, hverfandi hvél, "circling wheel," cf. rota.

12. hofa hilmir. Cf. Haraldssaga Hárfagra, c. Ix. 1 hilmir vébrautar : praeses fani, rex (Egilsson).

13. ungsamligr. Bugge reads vegsamligr, "glorious," in place of ungsamligr, which is not found either in old or modern Icelandic. (Småstykker), p. 112. 
14 Maðr er manns gaman

ok moldar auki

ok skipa skreytir

homo mildingr.

I5 Lögr er vellanda vatn

ok víðr ketill

ok glömmungr grund.

lacus lofoungr.

16 Ýr er bendr bogi

ok brotgjarnt járn

ok fífu fárbauti

arcus ynglingr.

14. Mađr er manns gaman. This phrase occurs also in Hávamál xLvir., whence it is doubtless borrowed.

skipa skreytir. Cf. Fornmanna sogur xI. 187. skautreina skreytir : exornator navium (Egilsson).

15. vellanda vatn, 687 ; all other texts have vellandi vimr (i.e. vimur), "hervorquellende flut." Cf. the Norwegian poem (Wimmer).

glömmungr, name of a fish in the pulor, Snorra Edda, p. 286.

16. $\bar{Y} r$. The character found here is regularly used for $Y$ in the Icelandic inscriptions, none of which are much earlier than 1300 . Cf. Kålund, Aarb. f. n. O. 1882, p. 98 ff.

brotgjarnt jarn $=y r$, a different word from $y r$, bow. Cf. ár of the Norwegian poem, kaldyr of Merlínusspá and kald $6 r=$ ferrum fragile of Haldorsen (Wimmer). 
14 Man = delight of man

and augmentation of the earth

and adorner of ships.

15 Water $=$ eddying stream

and broad geysir

and land of the fish.

16 $\dot{Y} r=$ bent bow

and brittle iron

and giant of the arrow.

brotgjarnt = brittle. Cf. Egill Skallagrímsson's Arinbjarnar drápa, v. 1 : hloðk lofköst panns lengi stendr

6brotgjarnt i bragar túni

(exegi monumentum aere perennius).

For brotgjarnt járn, 749 has bardaga gangr, "journey of battle"; JO $b$, bardaga gagn, "implement of battle."

Fífu fárbauti, JO $b$; fífa, poetical word for "arrow"; cf. bulor, Snorra Edda, p. 281.

Fábauti, a giant, father of the god Loki, Gylf. c. xxxı1., Skm. c. xvr., hence in poetry a generic term for giant. 749 has fenju fieygir, "speeder of the arrow." 


\section{APPENDIX}

Abecedarium Nordmannicum.

From Codex Sangallensis 878, fol. 321, a 9th century MS. of Hrabanus Maurus containing the earliest example of the sixteen letter alphabet of the Viking Age. Cf. Mullenhoff and Scherer, Denkmäler deutscher Poesie und Prosa $_{(3)}$ p. 19 (Berlin, 1892); for facsimile, Wimmer, Die Runenschrift, p. 236 :-

Feu forman,

Ur after,

Thuris thritten stabu,

Os ist himo oboro,

Rat endost ritan

Chaon thanne cliuôt.

Hagal, Naut hab\&

Is, $\mathrm{Ar}$ endi Sol,

Tiu, Brica endi Man midi

Lago the leohto,

Yr al bihabet.

In the MS. the Scandinavian Runic characters are found. In addition : 1. Under Feu forman WREA in English Runic letters and $T$ with one stroke as in v. 9. 7. Above Hagal an English $H$ with two crossbars. 8. Above $\mathrm{Ar}$ an English A. 9. Above Man an English M. 11. Above $\mathrm{Yr}$ a variety of English Y. 


\section{THE HEROIC POEMS}

Res gestae regumque ducumque et tristia bella

Horace

3-2 



\title{
INTRODUCTION
}

\author{
WALDHERE
}

In the year 1860 Professor E. C. Werlauff of the Royal Library, Copenhagen, was looking through some odds and ends of parchment brought back from England by the Icelandic scholar Grimur J. Thorkelin, the first editor of Beowulf, when he came upon two leaves of Anglo-Saxon MS. which had evidently been used in the binding of a book. Upon examination they proved to contain fragments of the Waltharius story, hitherto unknown from English sources, and in the same year Professor George Stephens brought out the editio princeps styled Two Leaves of King Waldere's Lay.

It was a popular story on the continent and several versions of it are preserved; cf. especially Learned, The Saga of Walther of Aquitaine (Baltimore, 1892), and Althof, Waltharii Poesis, 1. 17-23 (Leipzig, 1899).

1. By far the most complete, as also the earliest, of the continental forms is the Latin epic of Waltharius by Ekkehard of St Gall, the first of that name, ob. 973. It is a poem of 1456 hexameter lines, composed according to a later namesake of the author (usually known as Ekkehard IV) as an academic exercise in the Vergilian mood, dictamen magistro debitum. An occasional phrase or turn of syntax betrays its Teutonic origin; cf. Althof, W. $P$. I. 28-32, 44-57, etc.: and Ker, The Dark Ages, pp. $222 \mathrm{ff}$. (Edinburgh, 1904).

Briefly summarised, the story runs as follows: At the time of the great Hunnish invasions there ruled in Gaul three princes of Teutonic blood: (1) Gibicho, king of the Franks, at Worms; his son was called Guntharius. (2) Here- 
ricus, king of the Burgundians, at Châlon-sur-Saône; his daughter Hiltgunt was betrothed to Waltharius, son of (3) Alpharius, king of Aquitaine. Attacked by a countless army of the Huns, they could not but submit and render hostages to Attila. In place of Guntharius, who was then too young, Gibicho sent Hagano of Trojan blood; but the others were forced to deliver up their own children. The hostages were well treated by Attila and raised to high positions at the Hunnish court. But on the death of Gibicho Guntharius revolted and Hagano fled to Worms. Thereupon Attila, fearing lest Waltharius should follow the example of his sworn companion, proposed to wed him to a Hunnish maiden. Waltharius, however, induced him to withdraw the proposition and prepared for flight with Hiltgunt. One night while the Huns were heavy with wine, they slipped away, carrying much treasure with them. They fled by devious ways and all went well till after they had crossed the Rhine by Worms. Now at last they felt out of danger; but Guntharius had heard of their arrival and thought only of recovering the tribute paid by his father to the Huns. Hagano tried to turn him from so discreditable and dangerous a venture; but Guntharius would not be gainsaid. With twelve chosen warriors, of whom the unwilling Hagano was one, he fell upon Waltharius, who was resting in a defile of the Vosges. He demanded the treasure and the maiden, and Waltharius, when his offer first of 100, then 200 rings had been refused, made a stubborn resistance. The position was impregnable; eight of the Franks he slew in single combat and, when the three survivors attacked him with a trident, he was equally successful. Guntharius and Hagano then drew off; on the following day Waltharius, who had left his strong position, was waylaid by them and a furious combat ensued, in which Guntharius lost a leg, Hagano an eye and Waltharius his right hand'.

Sic, sic, armillas partiti sunt Avarenses. (v. 1404)

1 Hence the lords of Wasgenstein,-some ten miles as the crow flies from Worms-the traditional site of the battle, bore as their coat of arms six white hands on a red field; cf. the seal of Johann von Wasichenstein (1339), figured by Althof, Das Waltharilied, pp. $216 \mathrm{ff}$. 
After a formal reconciliation the Franks returned to Worms and Waltharius at length reached home where, after his marriage to Hiltgunt and his father's death, he ruled successfully for thirty years.

2. Waltharius is paraphrased in part in the Italian Chronicon Novaliciense, II. cc. 7-13 (cf. Bethmann, MGH. ss. vir. 73-133), where however the story is attached to a local hero, a champion of the Lombard king Desiderius (757-774).

3. There are moreover a few strophes extant of a BavarianAustrian epic of the first part of the thirteenth century, which give a somewhat less sanguinary version of the story.

The exceedingly dilapidated fragment from Graz (cf. Müllenhoff, $Z f d A$. xII. 280 ff.) tells how Walther learned for the first time from Hagen, who was on the point of departure from the Hunnish court, that he had been betrothed to Hiltgund; cf. Heinzel, Die Walthersage, pp. 13 ff. (Wien, 1888).

A somewhat longer fragment, 39 strophes, is preserved in two Ms. leaves from Vienna (cf. Massman, $Z f d A$. II. $216 \mathrm{ff}$.).

(a) After leaving Worms Walther and Hiltgund are escorted home to Langres by Volker and sixty of Gunther's knights. A messenger is sent ahead to Walther's father Alker (or Alpker), who, overjoyed at the news, prepares for their reception.

(b) Hildigunde Brûte describes Hiltgund's life at Langres, Walther's passionate love and the preparations for the wedding, to which even Etzel (Attila) and his wife are invited.

4. There are numerous incidental references in the Nibelungenlied

(str. 2281,

Nu wer was der âfem schilde vor dem Wasgensteine saz,

Dô im von Spâne Walther sô vil der mâge sluoc. Str. 1694,

Er und von Spâne Walther; die wuohsen hie ze man, Hagen sand ich wider heim: Walther mit Hiltegunte entran) and other Middle High German sources; cf. Althof, Das Waltharilied, pp. 180-9. 
5. In the pioriks saga af Bern, cc. 241-4 (Bertelsen, II. $105 \mathrm{ff}$ ), a thirteenth century Norwegian compilation from North German ballads, the story is simplified; Gunther has disappeared and Hogni is an agent of the Hunnish king.

Valtari af Vaskasteini, nephew of Erminrikr, king of Apulia, and Hildigund, daughter of Ilias of Greece, hostages to Attila, flee by night from the Hunnish court, taking with them a vast treasure. Pursued by Hegni and eleven knights, Valtari turns to bay, kills the eleven Huns and puts Hggni to flight. But as Valtari and Hildigund are feasting after the battle, Hogni returns to the attack; whereupon Valtari strikes him with the backbone of the boar which he is eating. Hggni escapes with the loss of an eye and the fugitives make their way to Erminrik's court without more ado.

6. There is moreover a Polish version of the story, the earliest form of which is to be found in the Chronicon Poloniae by Boguphalus II, Bishop of Posen, ob. 1253; cf. Heinzel, Das Waltharilied, pp. $28 \mathrm{ff}$. and Althof, W. $P$. I. 17-23.

Here Wdaly Walczerz (Walter the Strong) is a Polish count who carries off Helgunda, a Frankish princess, whose love he has won by nightly serenades. At the Rhone be is overtaken by the betrothed of the princess, who challenges him to battle. The pursuer is slain and Walczerz carries home his bride to Tynecz by Cracow. The sequel, which relates how Walczerz is betrayed by Helgunda, cast into prison and helped in the end to vengeance by the sister of his gaoler, has nothing to do with the original story.

It has been suggested that the version found in pirriks saga represents the original form of the story. This is most improbable; for while Guthhere appears in Waldhere, by at least two centuries the earliest in point of date, the episode in pioriks saga has gone through the ballad process of simplification. It is unfortunate that so little remains of Waldhere; but it may be assumed that in general outlines it followed the story of Waltharius. It varied of course in detail ; the characterisation of the heroine is vastly 
different. Contrast with Waldhere A the corresponding passages of Waltharius :

v. 544: In terramque cadens effatur talia tristis:

"Obsecro, mi senior, gladio mea colla secentur,

"Ut quae non merui pacto thalamo sociari

"Nullius alterius patiar consortia carnis";

v. 1213: "Dilatus jam finis adest; fuge domne propinquant; and pirriks saga, c. 243: Herra, harmr er bat, er bu skallt.i. beriaz við.xij. riddara. Rið hoelldr aptr oc forðu binu liui. Nor is it likely that the grotesque ending of Waltharius found a place in the English version. Moreover it appears that Waldhere encountered first Hagena, then Guthhere, whereas Guntharius and Hagano made a combined attack upon Waltharius.

It may be advisable to say something on the historical bearings of the story, discussed at length by Heinzel, Althof, and Clarke, Sidelights on Teutonic History in the Migration Period, pp. 209-231.

Aetla (Attila) is of course the great king of the Huns ob. 453, the flagella Dei, who terrorised Europe for some twenty years until defeated by Aetius on the Catalaunian plains; cf. Chambers, Widsith, pp. 44-48.

Guthhere (the Gunnarr-Gunther of the Old Norse and Middle High German Nibelung cycles) is the historical king of the Burgundians, who in the year 411 set up the Emperor Jovinus and, as a reward for surrendering his puppet, was allowed to occupy the left bank of the Rhine. For twenty years he ruled at Worms: then, perhaps under pressure from the Huns, he invaded Belgic Gaul and was thrown back by Aetius (435). Two years later he was defeated and slain by the Huns, and the sorry remnants of his people took refuge in the modern Burgundy. $\mathrm{He}$ is the Gundaharius of the Lex Burgundionum issued by his successor Gundobad in 516; cf. Chambers, Widsith, pp. 60-63.

In Waltharius however he is represented as a Frank, Hiltgunt and Herericus as Burgundians; for, since in the tenth century Worms was Frankish, Chalon-sur-Saône Burgundian, Ekkehard applied the political geography o 
his own time to a story of the migration period. It is quite uncertain therefore of what nationality these persons really were. Learned suggests that Herericus may be a reminiscence of the Chararicus who ruled Burgundy after the Frankish conquest (Gregory of Tours, IV. 38). But as in the case of Waltharius himself, nothing definite is known.

In the Anglo-Saxon fragments Waldhere is simply called 'the son of Aelfhere'-the Alpharius of Ekkehard, v. 77. Hence it has been thought that, as Aquitaine was held by the Visigoths in the days of Attila, the hero belonged to that people-a view most probably held in the later Middle Ages; e.g. he is called Walther von Spanje, Walter of Spain, in the Nibelungenlied. But it is likely that the original story had some native name, which has been displaced by the classical 'Aquitania.' Now the battle between Waldhere and his foes took place in the Vosges (Vosegus, Ekkehard passim: vor dem Vasgensteine, Nibelungenlied, 2281), whence he is styled Valtari af Vaskasteini in pioriks saga; and so before the time of Ekkehard the name of the Vosges must have been confused with Vasconia=Aquitania; cf. the "Wessobrunner Gloss" of the eighth century: Equitania: uuasconolant ${ }^{1}$.

A different indication is furnished by the MHG. fragments: there too he is called der vogt von Spanje, but his home is placed at Lengers, the French Langres (dept HauteMarne), no very great distance from Chalon-sur-Saône, the home of Hiltgunt in Ekkehard, v. 52. Of course the Merovingian conquest of Gaul had hardly begun as yet; but it is not at all unlikely that there were small Teutonic communities to the S.W. of the Vosges already in the first half of the fifth century. For certain Teutonic place-names in that district confirm the statement of Eumenius that Constantius Chlorus settled "barbarian cultivators" in the neighbourhood of Langres; ef. Chadwick, Heroic Age, p. 162; Zeuss, Die Deutschen und die Nachbarstämme, pp. 336, 582-4. Waldhere may or may not have belonged 1 Cf. P.G.(2) III. 707. 
to one of these communities: this much at least is certain that, like Sigurd and other heroes of the migration period, he was a character of no historical importance.

\section{Fins.}

The Finn fragment, incomplete at the beginning and the end, was discovered in the Lambeth Palace Library towards the end of the seventeenth century. The MS. has since been lost; luckily it had been printed in Linguarum Veterum Septentrionalium Thesaurus, I. 192 ff. (London, 1705), the monumental work of Dr George Hickes, the non-juring Dean of Worcester and one of the most devoted of those eighteenth century scholars to whom we owe so much.

The story of Finn must have been popular in AngloSaxon times. It is the subject of an episode in Beowulf, $v v$. 1068-1159, and three at least of its characters are included in the epic catalogue of Widsith:

v. 27. Finn Folcwalding (weold) Fresna cynne;

v. 29. Hnæf Hocingum;

v. 31. Sxfer Sycgum.

Moreover the Finn filii Fodepald-Nennius Interpretatus, Finn ( filii Frenn), filii Folcvald ${ }^{1}$ - who appears as an ancestor of Hengest in Historia Brittonum, $\S 31$, a mistake for the Finn Godwulfing of other Anglo-Saxon texts (e.g. Chronicle $547 \mathrm{~A}$ ), is clearly due to acquaintance with the story of Finn, the son of Folcwald?

From the continent evidence is scanty; the name Nebi (Hnæf) is occasionally found in Alemannic charters and Thegan, Vita Ludovici, c. II., gives the following as the genealogy of Hildegard, the wife of Charlemagne: Godefridus dux genuit Huochingum, Huochingus genuit Nebi, Nebi genuit Immam, Imma uero Hiltigardam; cf. Müllenhoff, $Z f d A$. XI. 282.

From Beowulf, $v$. 1068-1159, it appears that Hnaef, a vassal prince of the Danes, met his death among the Frisians at the court of Finn. The reasons for his presence there are

1 Mommsen, Chronica Minora, p. 171 (Berlin, 1898).

2 Chadwick, Origin of the English Nation, p. 42. 
nowhere stated in the episode or in the fragment. Very probably they were connected by marriage; the episode at least suggests that Hildeburh, described as Hoces dohtor in v. 1076, was the wife of Finn. She may have been Huaef's sister, since in Widsith, v. 29, Hnaef is said to have ruled the Hocingas, and this would agree with v. 1074, where Hildeburh bewails the loss of sons and brothers, perhaps a poetical use of plural for singular; cf. vv. 1114-1117. Hnaef's followers, led by a certain Hengest, hold out in the palace-hall and inflict such fearful loss upon the Frisians that Finn is forced to come to terms. An agreement is made-in flat defiance of the spirit of the comitatus-and peace is kept throughout the winter. But when spring returns, Oslaf and Guthlaf, two of Hnaef's retainers (cf. Ordlaf and Guplaf of Finn v. 18) make their way home. Determined to avenge their fallen lord, they collect reinforcements and return to Friesland, where they wipe out their dishonour in the blood of Finn and all his followers.

The story opens with the fall of Hnaef; nothing is known of its antecedents. The elaborate superstructure reared by Müllenhoff (Nordalbingische Studien, 1. 157) and Simrock (Beowulf, p. $190 \mathrm{ff}$.) - the death of Folcwald at the hands of Hoc, the settlement of the blood-feud by the marriage of Finn and Hildeburh, the subsequent murder of Hnaef while on a visit to the Frisian court-is pure hypothesis, erected on analogy with the Ingeld story; cf. Beowulf, vv. 2020-2066 and Saxo, Book vi. There is no reason for ascribing treachery to Finn-Eotena treowe (Beow. v. 1071) refers to the loyalty of Hnaef's men, not to the bad faith of the Frisians-and it is just as probable that Hnaef was the aggressor.

The episode in Beowulf is to be regarded as a paraphrase of some full-length treatment of the subject; cf. Odyssey viII. 499 and the cyclic poem of the Sack of Troy ('IAior Mépcic)'. But it is not easy to square the fragment with it. On the whole it seems most reasonable to assume that the fragment opens after the death of Hnaef, describes the battle hinted 1901).

1 D. B. Monro, Homer's Odyssey, Books xim-xxxr, pp. $371 \mathrm{ff}$. Oxford, 
at in Beowulf and breaks off just before the armistice of $v$. 1085. The hearogeong cyning would then be Hengest, the folces hyrde Finn. It is true that in Beowulf, v. 1085, Hengest is styled beodnes Jegne, an epithet scarcely compatible with hearogeong cyning, since in Anglo-Saxon epic poetry the title cyning is confined to ruling princes. Moreover it would seem from Finn, v. 43, that there had been at least five days fighting, whereas in Beowulf the battle was over in a single night. These difficulties have given rise to divergent views as to the precise moment in the story to which the fragment relates; Möller (Altenglische Volksepos, p. 65) places it between $v v$. 1143-4 of Beowulf, Bugge (P.B.B. XII. $20 \mathrm{ff}$ ), before the death of Hnaef. But the balance of probability is in favour of the view expressed above ${ }^{1}$.

\section{DEOR.}

The MS. of Deor is to be found on fol. 100 of the Exeter Book, the mycel Englisc boc be gehwylcum pingum on Leodwisan geworht, presented to Exeter by Bishop Leofric (10501072), and still preserved in the Cathedral Library there.

Setting aside $v v$. 23-34, the poem consists of six short strophes of irregular length followed by a refrain. Each of the first five strophes recounts some dolorous episode from heroic story, Weland's captivity at the hands of Nithhad, the Geat's hopeless love for Maethhild, the thirty years of exile suffered by Theodric, the sixth the poet's own misfortunes. The form is almost unique in Anglo-Saxon poetry, the only other instance being the so-called First Riddle of Cynewulf with its refrain ungelic is us. It is usually styled Deor's Lament (des Sängers Trost) and reckoned among the lyrics, but the only passage which recalls the Wanderer and the

1 In a paper read before the Philological Society on Dec. 6th, 1912 , Dr R. W. Chambers has suggested that the fight was a three-cornered affair. Hnaef of the Healf-Dene and Garulf of the Eotenas came to blows at a meeting of princes. Hnaef was slain and Finn stepped in to end the battle, afterwards taking Hengest into his service. An outline of the argument is given in no. 4442 of the Athenaeum and on pp. 168-9 of his edition of Wyatt's Beowulf (Cambridge, 1914). In the meantime we are awaiting his promised Introduction to the Study of Beowulf. 
Seafarer, the Husband's Message and the Wife's Complaint, is $v v$. 28-34, which is generally recognised to be a late homiletic addition. Deor has lost his all, but the prevailing note is hope rather than despair. The refrain seems conclusive on that point; Weland wreaked vengeance on his oppressor, Beadohild brought forth a mighty son, Theodric won back his kingdom, the cruel Eormanric died a bloody death. Their troubles were surmounted, so may Deor's be. With Lawrence (Mod. Phil. Ix. 23), rather may we call the poem a veritable Consolatio Philosophiae of minstrelsy.

\section{HILDEBRAND.}

The fragment of the Hildebrandeslied, the only surviving relic of German heroic poetry, was found on the outer cover of a theological MS.-No. 56 in the Landesbibliothek at Kassel. This Ms. was written in the early part of the ninth century, and from a palaeographical point of view has considerable traces of Anglo-Saxon influence. Fulda was probably its home'; but the variations presented as well in language as orthography are so great that it cannot be classified as a specimen of any known dialect. High German and Low German forms are found side by side, even in the same word.

A convenient table of the dialectical peculiarities has been given by Mansion in his Ahd. Lesebuch, p. $113 \mathrm{ff}$. (Heidelberg, 1912), frorn which the following particulars are taken :

\section{Consonants.}

1. Original $p$ and $t$ remain as in Old Saxon; cf.

v. 88 werpan, 62 scarpen.

v. 16 heittu, 27 ti, 52 dat.

2. Orig. $k$ becomes ch initially and after consonants as in O.H.G.; cf. v. 28 chud, 10 folche etc.:

elsewhere it is represented indifferently by $k, h, c h$; $\mathrm{cf}$.

v. $1 i k, 17$ ih, 13 chunincriche.

1 Hiltibraht for Hiltibrant is paralleled in other documents from Fulda ; cf. Kauffmann, Festgabe fur Sievers, p. 136 ff. (Leipzig, 1896) and Kögel, P.G.2 II. 74. 
3. Orig. $t$ becomes regularly $t$ as in O.H.G.; cf. $v .35$ truhtin, 44 tot.

4. Orig. $t$, when final, becomes $p$ : cf. $v .27$ leop, $v .34$ gap ; in other positions we find $b$ : cf. $v .30$ obana, etc. ( pist, prut, sippan, hevane are exceptions.)

5. Orig. $z$ regularly becomes $g(v .37$ geru etc.), except when final, where we find $c$; cf. $v .43$ wic, 55 taoc.

6. Orig. $b$ normally becomes $d$; but cf. $v .3$ Hađubrant.

7. $n$ disappears before $b, s$, as in Anglo-Frisiau and generally in the Heliand; cf. v. 5 guthamun, 12 odre, 15 usere.

8. Erratic use of $h$; cf. $v .6$ ringa (hringa), 57 bihrahanan (birahanan).

\section{Vowels.}

1. Orig. $\bar{o}$ is represented indifferently by $o$ and $u o:$ cf. v. 8 frotoro, 11 cnuosles.

2. Orig. $\bar{e}$ is represented by ae and $\ell$ : cf. v. 19 furlaet, 61 lęttun.

3. Orig. $a u$ (O.H.G. ou) is represented by $a u$ and $a o$ : cf.

v. 55 rauba. 53 taoc; sometimes also by $o$ in cases where O.H.G. has $\bar{o}$; cf. $v .1$ gihorta, 18 floh; but on the other hand ao appears in $v .22$ laosa, 55 aodlihho.

4. Orig. $a i$ is represented in a variety of ways:

$a i, v .65$ staimbort?; ei, v. 17 heittu; $\propto$ e, v. 17 hatti; ae, v. 22 raet; $e, v .47$ heme; \&, v. 52 enigeru.

Perhaps the most satisfactory solution of the problem is that put forward by Francis A. Wood, P.M.L.A. xI. 323-330, who argues that in its present form the Hildebrandeslied goes back to an Old Saxon poem current in the eighth century; heard from the lips of a Low German minstrel, it was written down in High German orthography and written down from memory, as is shown by the frequent deviations into prose. The existing MS. is not the archetype, but a copy of the original; the meaningless repetition of darba gistontun after $v .26$ seems conclusive on this point ${ }^{1}$.

1 The exact converse of this view is vigorously expressed by Holtzmann, Germania, Ix. 289 ff. and Luft, Festgabe an K. Weinhold, pp. 27 ff. (Leipzig, 
The hero of the poem is that Hildebrand who occupies a far from insignificant position in the Nibelungenlied and the poems of the Heldenbuch. The story of the fragment, unknown from either of these sources, is concerned with the meeting of Hildebrand and his son Hadubrand. Leaving his wife and child at home Hildebrand has followed Dietrich to the court of Etzel, and now returning after thirty years of exile finds his son arrayed against him. He learns their kinship and reveals himself; but Hadubrand, suspecting treachery, refuses to believe him. The fragment breaks off just as the fight begins; but there can be no doubt that as in the Sohrab and Rustum stury from the Shah-Nameh the father is obliged to slay his son ${ }^{2}$.

The whole atmosphere of the fragment forebodes a tragic sequel, though it is true that later German poems on the subject, as well as the closely related episode in pirriks saga, cc. 405-409 (Bertelsen, II. 471; also in Holthausen's Altisländisches Lesebuch, p. 24 ff.), end happily with the mutual recognition of the father and the son. Such are:-

1. The fifteenth century Der vater mit dem sun, of Kaspar von der Rön; cf. Henrici, Das deutsche Heldenbuch, pp. 301 ff., translated by F. A. Wood, The Hildebrandslied, pp. $7 \mathrm{ff}$. (Chicago, 1914).

2. A bruadsheet of 1515 ; cf. von Liliencron, Deutsches Leben im Volksklied um 1530, pp. 84 ff.

Moreover an allusion to the death of Hadubrand is preserved in a poem found both in Saxo Book vil. (Holder, p. 244):

medioxima nati

Illita conspicuo species caelamine constat Cui manus haec cursum metae vitalis ademit. Unicus hic nobis haeres erat, una paterni Cura animi, superoque datus solamine matri. Sors mala, quae laetis infaustos aggerit annos, Et risum marore premit sortemque molestat,

1896); for the literature of the subject, cf. Braune, Ahd. Lesebuch $(7)$, p. 188 (Halle, 1911).

${ }^{2}$ A comparative study of the motive will be found in M. A. Potter, Sohrab and Rustem (London, 1899). 
and in Ásmundarsaga Kappabana, c. Ix. (Fornaldar Sögur, III. 355):

Liggr bar inn svási sonr at höföi

eptirerfingi, er ek eiga gat, oviljandi aldrs synjaðak.

There is one reference to Hildebrand in early English literature in the thirteenth century fragment, discovered in Peterhouse Library by the Provost of King's:

Ita quod dicere possunt cum Wade:

Summe sende ylues

and summe sende nadderes;

summe sende nikeres

the bi den watere (us. biden patez) wunien.

Nister man nenne

bute Ildebrand onne ${ }^{1}$.

These six lines are perhaps to be connected with the M.H.G. poem Virginal; see p. 60 .

1 Cf. Academy, Feb. 1896, No. 1241; Athenaeum, Feb. 1896, No. 3565.

D. R. P. 


\title{
BIBLIOGRAPHY OF THE HEROIC POEMS.
}

\author{
; WALDHERE. \\ Editions (with translation*).
}

*Stephens, G. Troo Leaves of King Waldere's Lay. Copenhagen, 1860. Muillenhoff, K. and Dietrich. ZfdA. xII. $264 \mathrm{ff}$., xxx. $259 \mathrm{ff}$. Rieger, M. Alt.- u. Angelsächs. Lesebuch, pp. xviij ff. Giessen, 1861.

*Haigh, D. H. Anglo-Saxon Sagas, pp. 125 ff. London, 1861.

Grein, C. W. M. Beowulf nebst den Fragm. Finnsburg u. Waldere, pp. 76 ff. Cassel u. Göttingen, 1867.

Weinhold, K., in Scheffel and Holder's Waltharius, pp. $168 \mathrm{ff}$. Stuttgart, 1874.

Wülker, R. P. Kleinere ags. Dichtungen, pp. 8 ff. Leipzig, 1879.

Grein-Wülker. Bibl. der ags. Poesie, I. 7 ff., 401 ff. Kassel, 1881-3.

Möller, H. Das ae. Volksepos, pp. lxxvj ff. Kiel, 1883.

Heinzel, R. Die Walthersage. Wien, 1888.

Kluge, F. Ags. Lesebuch (3), pp. 128 ff. Halle, 1902.

Holthausen, Ferd. Die ae. Walderebruchstiicke, with four autotypes (Göteborgs Högskolas Årskrift, 1899).

Trautmann, M. B.B. v. $162 \mathrm{ff}$; Xvi. $184 \mathrm{ff}$.

Strecker, K. Ekkehards Waltharius, pp. $94 \mathrm{ff}$. Berlin, 1907.

Fraatz, P. Darstellung der syntakt. Erscheinungen in den ags. Waldere Bruchstücken, pp. 7 ff. Rostock dissert., 1908.

Holthausen, F. Beowulf nebst den kleineren Denkmälern der Heldensage $_{(3)}$. Heidelberg, 1912-3.

Sedgefield, W. J. Beowulf ${ }_{(2)}$, pp. 105 ff. Manchester, 1913.

\section{English Translations.}

(For German etc., see Holthausen, op. cit.)

Gummere, F. B. The Oldest English Epic, pp. $167 \mathrm{ff}$. New York, 1909.

Clarke, M. G. Sidelights on Teutonic History during the Migration Period, pp. 219 ff. Cambridge, 1911.

\section{Commentaries.}

Bugge, S. Spredte iagttagelser (Tidskrift, virr. $72 \mathrm{ff}$., 305 ff.).

Kölbing, E. Die W.-Fragmente (E. St. v. 240 ff., 292 ff.).

Möller, H. Das ae. Volksepos, pp. 156 ff. Kiel, 1883. 


\section{Bibliography}

Müller, W. Zur Mythologie der deutschen Heldensage, pp. $11 \mathrm{ff}$. Heilbronn, 1886.

Dieter, F. Die Walderefragmente und die ursp. Gestalt der Walthersage (Anglia, x. $227 \mathrm{ff}$., xI. $159 \mathrm{ff}$.).

Symons, B. $P . G_{\text {.(2) }}$, IIr. $793 \mathrm{ff}$.

Kögel, R. $\quad P . G_{.(2)}$, Ir. $81 \mathrm{ff}$.

- Geschichte der deutschen Litteratur, I. 1. 275 ff. Strassburg, 1894.

Learned, M. D. The Saga of Walther of Aquitaine. Baltimore, 1892.

Cosign, P. J. De Waldere-Fragmenten (Verslagen en mededeelingen $d$. k. akad. van Wetensch., III. reeks, xII.). Amsterdam, 1895.

Binz, G. Zeugnisse zur germ. Sage in England (P.B.B. xII. 217 ff.).

Althof, H. Über einige Stellen im Waltharius u. die ags. WaldereFragmente. Weimar Programm. 1899.

— Waltharii Poesis. Leipzig, 1899-1905.

Das Waltharilied. Leipzig, 1902.

Über einige Namen im Waltharius (ZfdPh. xxxrv. 365 ff.).

Trautmann, M. B.B. xI. $135 \mathrm{ff}$.

Brandl, A. $P . G_{\cdot(2)}$, Ir. $986 \mathrm{ff}$.

Boer, R. C. Unterss. über die Hildesage (ZfaPh. xI. 1 ff.).

Roethe, G. Nibelungias u. Waltharius (Sitzb. der Berl. Akad. 1909, xxv. $649 \mathrm{ff}$.).

Eckerth, W. Das Waltherlied $(2)$. Halle, 1909.

Dröge, K. Nibelungenlied u. Waltharius (ZfdA. LIr. 193 ff.).

Clarke, M. G. Sidelights, pp. $209 \mathrm{ff}$.

Chadwick, H. M. The Heroic Age, passim. Cambridge, 1912.

\section{The Finn Fragment.}

Editions (with translation*).

Hickes, G. Linguarum Veterum Septentrionalium Thesaurus, I. $192 \mathrm{ff}$. Oxford, 1705.

*Conybeare, J. J. The British Bibliographer, Iv. $261 \mathrm{ff}$. London, 1814.

* Illustrations of Anglo-Saxon Poetry, pp. $175 \mathrm{ff}$. London, 1826.

Grundtvig, S. Bjovulfs Drape, pp. xl ff. Köbenhavn, 1820.

Kemble, J. M. Beowulf $(2)$, I. 238 ff. London, 1835.

Klipstein, L. Analecta Anglo-Saxonica, I. 426 ff. New York, 1849.

Ettmiuller, L. Engla and Seaxna Scopas and Boceras, pp. $130 \mathrm{ff}$. Quedlinburg, 1850.

*Thorpe, B. Beovulf, pp. $227 \mathrm{ff}$. Oxford, 1855 and 1875.

Grein, C. W. M. Bibl. d. ags: Poesie, I. 341 ff. Göttingen, 1857.

Grundtvig, S. Beowulfes Beorh, pp. $37 \mathrm{ff}$. Köbenhavn, 1861.

Rieger, M. Ags. Lesebuch, pp. 61 ff. Giessen, 1861. 
Wülker, R. P. Kleinere ags. Dichtungen, pp. 6 ff. Leipzig, 1879.

Grein-Wülker. Bibl. d. ags. Poesie, I. $14 \mathrm{ff}$. Kassel, 1881.

Möller, H. Das ae. Volksepos, Ir. vij ff. Kiel, 1883.

Kluge, F. Ags. Lesebuch (3), pp. 127 ff. Halle, 1902.

Trautmann, M. Finn u. Hildebrand (B. B. vir. $54 \mathrm{ft}$.). Bonn, 1903.

— Beowulf (B.B. xvI. 180 ff.). Bonn, 1904.

Heyne, M.-Schücking, L. L. Beowulf $f_{(9)}$, pp. 91 ff. Paderborn, 1910.

Sedgefield, W. J. $\quad$ Beowulf $_{(2)}$, pp. 99 ff. $\quad$ Manchester, 1913.

Holthausen, F. Beowulf $(3)$. Heidelberg, 1912-13.

Wyatt, A. J.-Chambers, R. W. Beowulf with the Finnsburg Fragment, pp. 158 ff. Cambridge, 1914.

\section{English Translations.}

(For German etc., see Holthausen, op. cit.)

Haigh, D. H. Anglo-Saxon Sagas, pp. 32 ff. London, 1861.

Brooke, Stopford A. History of Early English Literature, 1. $88 \mathrm{ff}$. London, 1892.

Garnett, J. M. Beowulf $(4)$, pp. 97 ff. Boston, 1900.

Child, C. G. Beowulf and the Finnesburh Fragment, pp. 89 ff. London, 1904.

Huyshe, W. Beowulf: An Old English Epic, pp. 200 ff. London, 1907.

Gummere, F. B. The Oldest English Epic, pp. $160 \mathrm{ff}$. New York, 1909.

Clark Hall, J. R. Beowulf and the Finnsburg Fragment $(2)$, pp. $156 \mathrm{ff}$. London, 1911.

\section{Commentaries.}

Ettmüller, L. Beowulf, pp. 36 ff. Zürich, 1840.

Uhland, L. Schriften zur Gesch. der Dichtung u. Sage, vin. 488 ff. (from Germ. II. 354 ff.).

Müllenhoff, K. Zur Kritik des ags. Volksepos (ZfdA. xI. 281 ff.).

— Nordalbingische Studien, I. $156 \mathrm{ff}$. Kiel, 1844.

Simrock, K. Beowulf, pp. 187 ff. Stuttgart u. Augsburg, 1859.

Haigh, D. H. Anglo-Saxon Sagas, pp. $29 \mathrm{ff}$.

Grein, C. W. M. Die hist. Verhältn. des Beowulfiedes (Eberts Jahrbuch, Iv. 269 ff.).

Holtzmann, A. Zu Beowulf (Germ. virI. 474 ff.).

Grein, C. W. M. Zur Textkritik der ags. Dichter (Germ. x. 422).

Bugge, S. Spredte iugttagelser (Tidskrift, vIII. $304 \mathrm{ff}$. ).

Dederich, H. Historische u. geographische Studien zum Beowulfiede, pp. $215 \mathrm{ff} . \quad K o ̈ l n, 1877$.

Möller, H. Das ae. Volksepos, I. 46 ff., $151 \mathrm{ff}$. Kiel, 1883.

ten Brink, B. P.G.(1), II. 1. 545 ff. Strassburg, 1893. 
Schilling, H. Notes on the Finnsaga (M.L.N. I. 89 ff., 116 ff.).

The Finnsburg Fragment and the Finn Episode (M.L.N. II. 146 ff.).

Bugge, S. Das Finnsburg-Fragment (P.B.B. xII. 20 ff.).

Jellinek, M. H. Zum Finnsburgfragment (P.B.B. xv. 428 ff.).

Clark Hall, J. R. Beowulf $_{(2)}$, pp. $202 \mathrm{ff}$.

Binz, G. P.B.B. xx. $179 \mathrm{ff}$.

Boer, R. C. Finnsage u. Nibelungensage (ZfdA. xuvir. $125 \mathrm{ff}$, $139 \mathrm{ff}$ ).

Holthausen, F. Beiträge zur Erklärung des ae. Epos (ZfdPh. xxvII. $123 \mathrm{ff}$.).

Klaeber, Fr. Anglia, xxvirr. 447. Archiv f. n. S. CXv. $181 \mathrm{ff}$.

Swiggett, G. L. Notes on the Finnsburg Fragment (M.L.N. xx. 169 ff.).

Rieger, M. Zum Kampf in Finnsburg (ZfdA. xuviIr. 9 ff.).

Klaeber, F. Zum Finnsburg-Kampfe (E. St. хxхıx. 307 ff.).

Brandl, A. P.G.(2) II. $983 \mathrm{ff}$.

Clarke, M. G. Sidelights on Teutonic History, pp. $177 \mathrm{ff}$.

Wyatt-Chambers. Beowulf, pp. 167 ff.

\section{DEOR.}

Editions (with translation *)

*Conybeare, J. J. Illustrations of A.-S. Poetry, pp. 240 ff. London, 1826.

Grimm, W. K. Deutsche Heldensage $(3)$, p. 22. Gütersloh, 1889.

*Thorpe, B. Codex Exoniensis, pp. 377 ff. London, 1842.

Klipstein, L. Analecta Anglo-Saxonica, II. $317 \mathrm{ff}$.

Ettmüller, L. Engla and Seaxna Scopas, pp. $211 \mathrm{ff}$.

Müller, Th. Ags. Lesebuch, pp. $171 \mathrm{ff}$. (1855 ?)

Rieger, M. Ags. Lesebuch, pp. $82 \mathrm{ff}$.

Grein-Wülker. Bibl. der ags. Poesie, r. 283 ff.

Kluge, F. Ags. Lesebuch $(3)$, pp. $139 \mathrm{ff}$.

Sedgefield, W. J. Beowulf $_{(2)}$, pp. $107 \mathrm{ff}$.

Holthausen, F. Beowulf $(3)$.

\section{English Translations.}

Haigh, D. H. A.-S. Sagas, pp. $102 \mathrm{ff}$. - Atlantic Monthly, LxvIr. 287. Boston and New York, 1891.

Gummere, F. B. The Oldest English Epic, pp. $185 \mathrm{ff}$.

\section{Commentaries.}

Muillenhoff, K. $Z f d A$. vII. 530 ff.; xI. 272 ff. ; xII. 261.

Grein, C. W. M. Germ. x. 422.

Meyer, K. Germ. xIv. $283 \mathrm{ff}$.

Die Dietrichsage. Basel, 1868.

Schipper, J. Germ. xIx. 333. 
Moller, H. Das ae. Volksepos, I. $115 \mathrm{ff}$.

Morley, H. English Writers(2), II. 15 ff. London, 1888.

Golther, W. Die Wielandsage (Germ. xxxIII. 449 ff.).

Heinzel, R. Über die ostgotische Heldensage, pp. 16 ff. Wien, 1889.

ten Brink, B. Early English Literature, pp. $60 \mathrm{ff}$. London, 1891.

Jiriczek, O. L. Deutsche Heldensagen, I. pp. $124 \mathrm{ff} ., 157 . \quad$ Strassburg, 1898.

Tupper, F. jun. Deor's Complaint (M.L.N. x. 125 ff.).

- Deor (M.Ph. Ix. 265 ff.).

- The Third Strophe of Deor (Anglia xxxvir. $118 \mathrm{ff}$.).

Binz, G. P.B.B. xx. $192 \mathrm{ff}$.

Schücking, L. L. Das ags. Gedicht von der "Klage der Frau" (ZfdA. xLVIII. $436 \mathrm{ff}$.).

Bugge, S. The Norse Lay of Wayland and its Relation to English Tradition (Sagabook of the Viking Club, II. $271 \mathrm{ff}$; also in Norwegian in Ark. f. n. F. xxvi. 33 ff.).

Schück, H. Bidrag til tolkning af Rök inskriften (Uppsala Univ. Arsskrift, 1908).

Brandl, A. $\quad P . G_{.(2)}$, II. $975 \mathrm{ff}$.

Zur Gotensage bei den AS. (Archiv f. n. S. oxx. 1 ff.).

Stefanovic, S. Zu Deor, v. 14-17 (Anglia, xxxIII. 397 ff. ; xxxvi. $383 \mathrm{ff}$; xxxVII. $533 \mathrm{ff}$.).

Lawrence, W. W. The Song of Deor (Mod. Phil. Ix. 23 ff.).

Chambers, R. W. Widsith, pp. 15 ff. Cambridge, 1912.

Clarke, M. G. Sidelights on Teutonic History, pp. $118 \mathrm{ff}$.

\section{Hildebrand.}

Editions.

v. Eckart, J. G. Commentarii de rebus Franciae orientalis, I. $864 \mathrm{ff}$. Wirceburgi, 1729.

Grimm, Die Brüder. Das Lied von Hildebrand $u$. Hadubrand, etc. Cassel, 1812.

Grimm, W. De Hildebrando...fragmentum. Göttingen, 1830.

Vollmer, A.-Hofmann, K. Das Hildebrandslied. Leipzig, 1850.

Grein, C. W. M. Das Hl. Marburg, 1858; Cassel, 1880.

Sievers, Ed. Das Hl., etc. Halle, 1872.

Wackernagel, W. Altdeutsches Lesebuch ${ }_{(5)}$. Basel, 1873.

Heinzel, P. Ü̈ber die ostgotische Heldensage, pp. $39 \mathrm{ff}$. Wien, 1889.

Müllenhoff, K.-Scherer, W. Denkmäler deutscher Poesie u. Prosa $a_{(3)}$, I. 2 ff.; II. 8 ff. Berlin, 1892.

Wadstein, E. Göteborgs Högskolas Arsskrift, IX. Göteborg, 1903.

Trautmann, M. Finn u. Hildebrand (B.B. vir.). Bonn, 1903.

v. Grienberger, Th. Das $H l$. Wien, 1908. 


\section{of the Heroic Poems}

v. d. Leyen, F. Älteste deutsche Dichtungen. Leipzig, 1909.

Braune, W. Althochdeutsches Lesebuch $(7)$, pp. 80 ff. Halle, 1911.

Mansion, J. Ahd. Lesebuch, pp. 113 ff. Heidelberg, 1912.

Holthausen, F. Beowulf $f_{(3)}$. Heidelberg, 1912-3.

\section{English Translations.}

(For German, see Braune and Holthausen, op. cit.)

Gummere, F. B. The Oldest English Epic, pp. 173 ff. New York, 1909.

Wood, F. A. The Hildebrandslied. Chicago, 1914.

Commentaries.

Lachmann, K. Über das Hildebrandslied (Kleinere Schriften, I. 407 ff.). Berlin, 1876.

Holtzmann, A. Germania, Ix. $289 \mathrm{ff}$.

Rieger, M. Ib. Ix. 295.

Schröder, O. Bemerkungen zur Hl. (Symbolae Joachimicae, pp. 189 ff.). Berlin, 1880.

Edzardi, A. P. B. B., viII. 480-90.

Möller, H. Über ahd. Alliterationspoesie. Kiel, 1888.

Kögel, R. $\quad P$. G.(2). II. $71 \mathrm{ff}$.

- Geschichte der deutschen Litteratur, I. 1. 211 ff. Strassburg, 1894.

Luft, W. Die Entwickelung des Dialoges im alten $\mathrm{Hl}$. Berlin dissert. 1895.

—Zum Dialekt des Hl. (Festgabe an K. Weinhold, pp. 29 ff.). Leipzig, 1896.

Kauffimann, F. Das Hl. (Festgabe für E. Sievers, pp. 124 ff.). Halle, 1896.

Erdmann, A. Bemerkungen zum HI. (P.B.B. xxir. 424 ff.).

Meissner, R. Zum Hl. (ZfdA. XLII. $122 \mathrm{ff}$.).

- Staimbort chludun (ib. xLvir. 400 ff.).

Joseph, E. Der Dialog des alten $H l$. (ib. xuIII. 59 ff.).

Busse, Br. Sagengeschichtliches zum Hl. (P.B.B. xxvr. 1 ff.).

Franck, J. Die Überlieferung des $H I$. (ZfdA. XLVII. l ff.).

Rieger, M. Zum $H l$. (ZfdPh. xLvir. 1 ff.).

Ehrismann, G. Zum Hl. (P.B.B. xxxiI. 260 ff.).

Klaeber, F. $H l .63$ f. (M.L.N. xxI. 110 ff.). Jottings on the Hl. (ib. xxvi. $211 \mathrm{ff}$ ).

Boer, R. C. De liederen van H. en Hadubrand. (Verslagen d. $k$. akad. van Wetensch., IV. reeks, IX.). Amsterdam, 1909.

Wadstein, E. Minneskrift utg. af filolog. samfundet, pp. 86 ff. (also in G. Högskolas A Arskrift, xvi.). Göteborg, 1910.

Collity, H. Zum HI. (P.B.B. xxxvi. 336 ff.). 


\title{
WALDHERE
}

\author{
A.
}

........hyrde hine georne:

"Huru Welande[s ge]worc ne geswicer monna ænigum, para ðe Mimming can hearne gehealdan. Oft æt hilde gedreas

5 swatfag ond sweordwund sec $[g]$ æfter oðrum. \&tlan ordwyga, ne læt ðin ellen nu gyt gedreosan to dæge, dryhtscipe [feallan] ..........Nu is se dæg cumen, pæt ðu scealt aninga oð̄er twega,

ro lif forleosan, orre langne dom agan mid eldum, Elfheres sunu.

Nalles ic ðe, wine min, wordum cid[e]

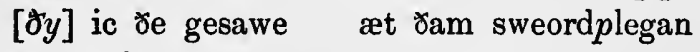
бurh edwitscype æniges monnes

15 wig forbugan, orøe on weal fleon, lice beorgan, reah pe laðra fela rinne byrnhomon billum heowun.

A 2. MS. Weland...20orc.

7. feallan supplied by Stephens.

13. MS. sweordwlegan.
5. MS. sec.

10. MS. lange.

A 1. hyrde: probably from hyrdan (heard), "to encourage"; cf. Elene, v. 841: $b a$ wæs hige onhyrded (Dietrich). 'It might also come from hyran, "to hear."

Bugge, however (Tidskrift, vin. 72), regards it as too abrupt an opening for a speech and refers hyrde to the sword Mimming, "carefully (Weland) tempered it." But Cosijn compares Beowulf, v. 2813: het hine brucan wel.

A 2. For the opening of a speech with huru cf. Guthlac, v. 332 and the Address of the Soul to the Body, v. 1:

Huru pæs behofap hælepa æghroylc.

Welande[s ge] $200 r c:$ cf. Beowulf, v. 454 , and Waltharins, $\nabla .964$; for the story of Weland, Beadohild, Niðhad and Widia see notes to Deor, pp. 70-73.

ne geswiced: cf. Beowulf, v. 1460 :

$$
\text { Manna ængum Nara he hit mid mundum gewand. }
$$

A 8. Mimming: Weland's most famous sword.

In piorik's saga, cc. $57 \mathrm{ff.}$., Mimir is Velent's master, Mimangr his masterpiece; cf. Biterolf and Dietlieb, vv. 115-181, Horn Child, III. 298:

"It is the make of Miming,

of all swerdes it is king,

And Weland it wrought," 


\section{WALDHERE}

\section{A.}

Eagerly she (sc. Hildegyth) encouraged him: "Weland's handiwork in very truth will fail no man who can wield the sharp Mimming. Many a time has warrior after warrior fallen in the fray, pierced by the sword and weltering in his blood. And in this hour, champion of Attila, let not thy prowess yield, thy knightly courage fail. Now is the day come when thou, son of Aelfhere, must lose thy tife, or else win lasting glory among men. Never will I taunt thee with reproachful words, $O$ lover mine, that in the clash of swords I have seen thee yield in craven fashion to the onset of any man, nor flee to the wall to save thy life, though many a foeman siuote thy corselet with his sword. But ever didst thou strive to

and continental references. (Maurus, Die Wielandsage, passim.) In Saxo, Bk Irr., however, Mimingus is the name of the satyrus robbed by Hotherus of a sword and ring.

A 4. hearne, phonetic spelling of heardne, "sharp"; cf. Beowulf, จ. 2067, Heaðobearna.

A 6. Attlan ordwyga; cf. Waltbarius, v. 106 : Militiae primos tunc Attila fecerat illos;

Nibelungenlied, str. 1735 :

$$
\text { Er und der von Spâne trâten manegen stîc, }
$$

For Teutonic princes in the service of Attila, cf. Jordanes, c. xxxvirr.

A 7. dryhtscipe: feallan supplied by Stephens to complete the verse. This leaves a lacuna of half a verse at the beginning of the next line. Accordingly Holthausen would expunge to dxge and read: gedreosan dryhtscipe. $\quad \mathrm{Nu}$ is se dxg cumen.

A 8. $[N u]$ is se dxg cumen.

$$
\begin{aligned}
& \text { ne læot fin ellen nu gyt, } \\
& \text { Nu is se dæg cumen. }
\end{aligned}
$$

At the end of 1.7 of the us. there is something illegible that may possibly be $n u$ (Holthausen, Die altenglischen Waldere-Bruchstilcke, p. 5); cf. Beowulf, v. 2646: Nu is se dæg cumen.

A 9. ođer twega; cf. Maldon, v. 207:

hie woldon ba ealle oðer twega,

lif forleosan oððe leofne gewrecan.

A 12-20, according to Heinzel (Walthersage, p. 7 ff.), refer to exploits in the service of Attila, which Hildegyth might possibly have witnessed from a tower or walled city; but the use of the demonstrative ram most probably limits them to the preceding day, especially as Bugge compares with weal Waltharius, $\nabla .1118$ :

Donec jam castrum securus deserat artum.

gesawe: Cosijn explains it as poetic licence, "saw" for " heard." 
Ac $\delta$ symle furðor mæl ofer mearce.

20 pæt $\delta \mathrm{u}$ to fyrenlice æt 万am ætstealle feohtan sohtest

Đy ic re metod ondred feohtan sohtest oðres monnes

wigrædenne. Weorða ðe selfne godum dædum, ðenden ðin God recce.

Ne murn $\delta u$ for $\gamma \mathrm{i}$ mece; e wear $\delta$ maðma cyst

25 gifeðe to eoce unc; $\delta y$ бu Guðhere scealt

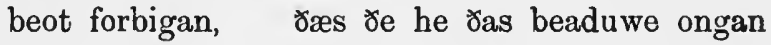
mid unryhte ærest secan.

Forsoc he Jam swurde ond 万am syncfatum, beaga mænigo; nu sceal beaga leas

3o hworfan from risse hilde, hlafurd secan ealdne eðel, oððe her ær swefan, gif he $\gamma a . . . . . . "$

B.

“......[me]ce bæteran

buton yam anum $\delta$ ic eac hafa on stanfate stille gehided.
A 25. MS. gifede,
31. MS. 8 .
B 1. MS. ce.

A 18. ac ðu symle furðor feohtan sohtest, mæl ofer mearce.

With the expression sohtest mæl, cf. the Icelandic legal term, sckja mól, "to press a suit." Feohtan is a noun in apposition to mæl and ofer mearce $=$ "into the enemy's country." The whole phrase may be translated " but ever thou didst seek to press home thy martial suit."

A 19. metod, here, as originally, "fate," "destiny" (cf. O.N. mjotuðr); nsually an epithet applied to the Creator.

A 20. feohtan, as in $\nabla .18$, to be taken as the acc. of feohte rather than as a verb. The instances of secan + infinitive noted by Callaway (The Infinitive in Anglo-Saxon, pp. 57, 286) are all taken from rather late prose works.

A 21. æt ðam ætstealle: ætsteall occurs twice elsewhere, in Guthlac, v. 150 :

$$
\begin{aligned}
& \text { him to ætstælle } \text { ærest arærde } \\
& \text { Cristes rode; pær se cempa oferwon } \\
& \text { frecnessa fela; }
\end{aligned}
$$

and as a place-name æt ætstealles beorh in a charter of Cnut; cf. Kemble, Codex Diplomaticus, Iv. $31^{2}$. The only translation which will suit all three passages appears to be "position" in the military sense; cf. Waltharius, 7. 1103: tali castro nec non statione locatus. 
press home thy martial suit. Wherefore I trembled for thy fate, for that too fiercely thou didst attack thy warlike adversary on the field of battle. Win honour for thyself by noble deeds and till then may God protect thee. Have no care for that sword; a peerless treasure is vouchsafed to thee to help us in our time of trouble; wherewith thou shalt humble Guthhere's pride, in that he unjustly began the strife against thee. He refused the sword and the casket of treasure with its many rings. Now ringless he shall leave this combat and return to the land of which he has long been lord, or perish here, if he...."

B.

"......a better [sword] save that one which I too have laid at rest in its jewelled sheath. I know that Theodric

A 25. eoce, phonetic for geoce; cf. Andreas, v. 1124, eogope, etc.

A 29. In support of the emendation bega leas, "without either," which is not absolntely necessary, Bugge brings up Lokasenna, xIIr.:

$$
\text { "Jos ok armbauga mundu æé vesa }
$$

A $30 \mathrm{ff}$., cf. Beowulf, v. 520 ff. (Cosijn).

B 1. The interpretation of this passage is very doubtful. The fragment opens towards the end of a speech by Guthhere, just before the swords are drawn for the last struggle. Presumably Guthhere, who prides himself on the excellence of his equipment (cf. Atlakvipa, vir.:

$$
\begin{aligned}
& \text { Sjau eigum salhüs sverpa full hverju, } \\
& \text { [hver eru beira hjolt or golli]. } \\
& \text { Minn veitk mar baztan mǽki hvassastan), }
\end{aligned}
$$

declares that Waldhere possesses no sword better than his own.

The meaning of stanfæt is disputed; elsewhere it is used for a receptacle of stone, such as the alabaster pot of ointment, and a parallel to the whole passage occurs in the Metra of Boethins xx. 151:

$$
\text { ond on stanum eac stille geheded. }
$$

The translation would then be "a better sword than that one which I have as well as this, stowed away in a stone-chest." .

But would Guthhere have left his most precious sword at home on an occasion like this? Moreover vaz is used for "sheath" in MHG. and scabbards set with precious stones are occasionally found in continental graves of the migration period; cf. the sword-sheath set with garnets from the grave of Childeric (ob. 481), and the gold band with red stones from the grave of Pouan (of Theodoric the Visigoth, who fell in the battle of the Catalaunian Plains? Cf. Lindenschmit, Handbuch der deutschen Althertumskunde I. $68,232 \mathrm{ff}$.).

In this case it would be translated as above. For the use of hydan in this sense cf. Homilies of AElfric (ed. Thorpe), rr. 246, 24,

Crist het hine hydan Jæt heard $28 e r n$.

Bugge restores the verse as follows:

[Ne seah ic mid mannum me]ce bæteran. 
Ic wat poet hine rohte Đeodric Widian

5 selfum onsendan ond eac sinc micel

marma mid бi mece, monig oðres mid him

golde gegirwan- iulean genam,

pæs de hine of nearwum Niðhades mæg,

Welandes bearn, Widia ut forlet-

Io Jurh fifela geweald for onette."

Waldere marelode, wiga ellenrof, -

hæfde him on handa hildefro $[f]$ re

gưbilla gripe- gyddode wordu $m$ :

"Hwæt ju huru wendest, wine Burgenda,

I5 poet me Hagenan hand hilde gefremede

ond getwæmde feðewigges? Feta, gif ou dyrre,

æt Jus heaðuwerigan hare byrnan.

Stanðed me her on eaxelum Elfheres laf,

god ond geapneb, golde geweorðod,

20 ealles unscende æðelinges reaf

to habbanne, ponne ha[n]d wereð

feorhhord feondum; ne bir fah wir me

ponne unmægas eft ongynnar,

mecum gemetad, swa ge me dydon.
B 4. MS. $i c$.
10. MS. gefeald.
21. MS. had.
12. MS. hildefrore.

18. MS. standað.

B 4. Nonsense as it stands in the as. Trautmann emends $i c$ to hine (the sword Mimming).

B 7-10; cf. Witige's speech to Heime in Alpharts Tod, str. 252 ff.:

Dar an solt du gedenken, dû uz ervelter degen

wie ich dir kam ze helfe unde vriste dir din leben.

Daz tet ich zuo Mûtâren, dâ half ich dir uz nôt,

dâ müestestû zewâre den grimmelichen tôt

dî und der von Berne beide genomen hân

wan daz ich in beiden sô schiere ze helfe kam.

The whole question of Dietrich's captivity among the giants is treated by Jiriczek, Deutsche Heldensagen $\mathrm{x}$. 182-271. The following are the most important passages in MHG. poetry :

1. Virginal (Zupitza, Deutsches Heldenbuch, v. $1 \mathrm{ff}$.). Dietrich loses his way near Castle Mutar, where Duke Nitger lives guarded by twelve giants. $\mathrm{He}$ is captured by one of these giants and held in close confinement till he wins the favour of Nitger's sister, who lets Hildebrand know of his master's plight. Hildebrand, Witige, Heime and others hasten to his aid; the giants are slain, the castle taken and Dietrich rescued from captivity.

2. Sigenot (Zupitza, D.H.B. v. 207 ff.). Dietrich is again captured by a giant and reseued by Hildebrand.

3. Laurin (Jänicke, D.H.B. 1. 199 ff.) treats of a captivity of Dietrich among the dwarfs.

A convenient summary of these poems will be found in F. E. Sandbach's Heroic Saga-Cycle of Dietrich of Bern (London, 1905). 
was minded to send it to Widia himself and much costly treasure with that blade and much beside it deck with gold. Nithhad's kinsman, Widia, the son of Weland, received the reward that had long been due for rescuing him from captivity. 'Through the giants' domain Theodric hastened forth."

Then spake Waldhere,-in his hand he grasped his trenchant blade, a comfort in the fray-the daring warrior, with defiant words : "Ha, friend of the Burgundians, didst thou deem in very truth that Hagena's hand had done battle with me and brought my days of combat to a close? Fetch, if thou darest, the grey corselet from me who am exbausted by the fray. Here it lies on my shoulders, even the heirloom of Aelfhere, good and broad-bossed and decked with gold, in every wise a glorious garment for a prince to wear, whose hand protects the treasure of his life against his foes. Never will it play me false, when faithless kinsmen return to the attack and beset me with their swords as ye have done.

B 10. gefeald, which does not occur elsewhere, should be emended to geweald; cf. Beowulf, v. 903, on feonda geweald (Kluge).

B 12. ms. hildefrore emended by Vietrich to hildefrofre. Cosijn points out that frore for frofre is also found in The Rule of St Benet, p. $10^{1}$ (ed. Logeman, E.E.T.S. 1888).

B 13. guðbilla gripe, abstract for concrete, "snijdend (tot den houw gereed) zwaard" [Cosijn], rather than "a gem of war-swords" (gripe $=0 \mathrm{ON}$. gripr).

B 14. wine Burgenda; cf. Atlakviba, xIx., vin Borgunda (emended to Borgunda họllvin by Gering), see introduction, p. 41.

B 19. geapneb has been translated "well-arched" and "crookednibbed" (B.T.), neither of which epithets is particularly appropriate to a corselet. On the other hand a mail-coat, found by Engelhardt (Denmark in the early Iron Age, p. 46, etc.) in the peat-mosses of Torsbjærg and often figured since, was strengthened or decorated with breast-plates (phalerae); cf. the "zierschieben" of bronze in the museums of Kiel, stettin, Hanover, etc., mentioned by Lindenschmit, Die Alterthilmer unserer heidnischen Vorzeit, riI. vij. taf. 3. These phalerae were ultimately of Roman origin; cf. Daremberg-Saglio, Dictionnuire des Antiquités grecques et romaines, Iv. 425, for examples from Crefeld and Mainz, especially the gravestone of $M^{\prime}$. Caelius who fell with Varus, in 9 A.D. Is it impussible therefore that, as a shield with its boss is styled cellod bord, "the beaked shield," in Maldon, v. 283, so the epithet geapneb, "broad-bossed," should be applied to a mailcost of this kind?

B 23. MS. pōn | un mægas with a lacuna of three or four letters at the end of the line, which Stephens filled by the insertion of yfle. Bugge (Tidskrift, virI. 306) and Holthausen (Beowulf (3), II. 173) declare that they can read bōn og | un mægas, though $\eta$ is found only in ON. Mss., not elsewhere in AS. Onga, the word they postulate, does occur in the sense of "sting," "point of an arrow" (Riddle xxiv. 4). They connect it with the 
25 Đeah mæg sige syllan se ðe symle byð recon ond rædfest ryhta gehwilces, se бe him to бam halgan helpan gelifeð, to Gode gioce, he pær gearo finder, gif ða earnunga ær geðenceð.

30 ponne moten wlance welan britnian æhtum wealdan, pæt is...."

B 30. MS. mtoten.

Frankish ăr $\gamma \omega \nu$ of Agathias, Ir. 5, and graves of the Merovingian period; cf. too the tridens of Waltharius, $\nabla .983 \mathrm{ff}$. (Althof, W.P. Ir. 382). In this case mægas = mæcgas, "warriors" (Diether, Anglia, xI. 106).

It were better perhaps to keep the reading ponne unmægas, which, if demanding a $a \pi a \xi \lambda \epsilon \gamma \delta \mu \epsilon \nu o \nu$, does fit in with sense and metre. Unmxgas 
Yet victory can be given by Him who is always prompt and regardful of everything that is good. For whosoever trusts in the Holy One for help, in God for succour, finds it ready to his hand, if first he be determined to deserve it. Thus can the great distribute their wealth and rule their possessions: that is......."

may be compared with sucb forms as unlonde (Walfisc, v. 14), "land that is no land," and translated " kinsmen who are no kinsmen."

B 26. recon; unless the text be normalised, it is quite unnecessary to emend to recen, there being sufficient evidence for recon (B.T.). 


\section{FINN}

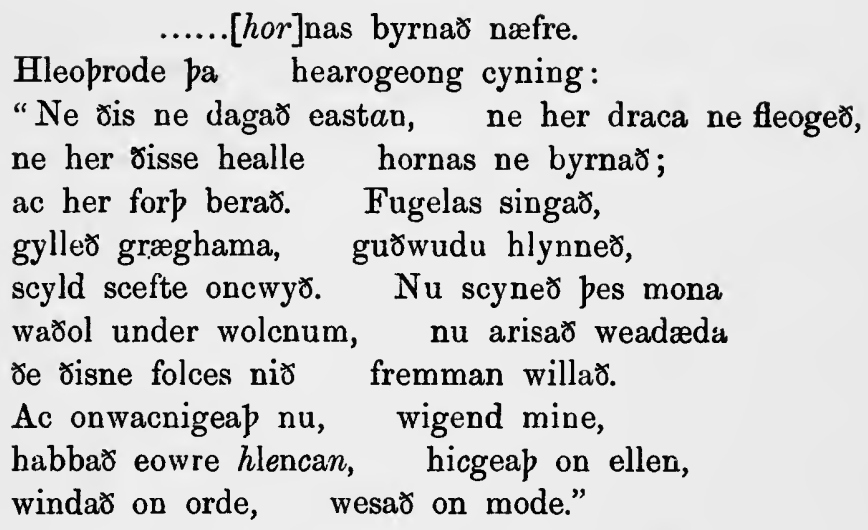

1. Hickes * nas.

3. H. eastun.

12. H. habbað eowre landa, hie geap on ellen.

1. The fragment opens in the middle of a word; Grein (Beowulf, p. 75) supplies [beorhtre hor]nas.

2. hleoprode $p a$, a satisfactory half-verse of the $\mathrm{E}$ type, though Trautmann and others would reverse the order on the analogy of Andreas, vv. 537, 1360, etc.

hearogeong cyning. Following Grundtvig all modern editors emend to heapogeong-quite unnecessarily to my mind. Hearogeong (for heorugeong) is a perfectly admissible form, with the same meaning, whatever that may

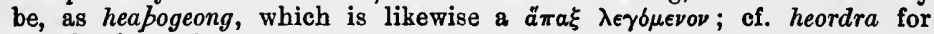
heardra in v. 28.

cyning, probably the Hengest of v. 19. He is however styled peodnes $\gamma_{\text {egn }}$ in Beowulf, v. 1085. This may be a loose or proleptic usage of cyning; cf. Abbo, de Bello Parisiaco, 1. 38: Solo rex verbo, sociis tamen imperitabat; and Chadwick, Studies on Anglo-Saxon Institutions, pp. $301 \mathrm{ff}$. (Cambridge, 1905).

3, 4. Cf. Grottasǫngr. xIx. :

\begin{tabular}{|c|c|}
\hline , & $\begin{array}{l}\text { pat mun } \\
\text { hinig of }\end{array}$ \\
\hline
\end{tabular}

For the portent of a fiery dragon, cf. Saxo, Bk vr. (Holder, p. 175), and the Chronicle 793 E, wæron gesecwene fyrene dracun on pam lyfte fleogende (before the coming of the Northmen).

5, 6. ac her for $p$ berad. Most editors have assumed a lacuna of at least two half-lines after berað. Hence Grein (Beowulf, p. 75) would supply fyrdsearu fuslicu

and Bugge (P.B.B. xII. 23), feorhgeniðlan

flacre flanbogan.

fyrdsearu rincas 


\section{FINN}

Then cried the king young in war, "It is not dawn that glows in the east. There is no dragon flying here, nor are the gables of this hall aflame. But here they are hurrying forth. The birds are singing, the grey-coat is howling, the war-wood is clanging, shield echoing when smitten by the shaft. Now shines the moon through rifts in the clouds; now fearful deeds are afoot that will bring on a pitched battle here. But wake ye now, my warriors, don your corselets, think on your prowess, dash to the van, be of good courage."

Schilling, however (M.L.N. 1. $116 \mathrm{ff}$.) points out that no subject is required in A.S. where one is perfectly well understood; cf. Pogatscher, Anglia, xxirr. $261 \mathrm{ff}$. Moreover berad is to be taken as intransitive. "But here they (the Frisians) are hurrying forth"; cf. Elene, v. 45:

$$
\text { rincas under roderum, }
$$

beran ut præce

and Andreas, v. 1220; also the mod. Eng. use of "bear" in nautical phrases.

6,7 . There are several ways of taking this passage:

(1) fugelas = "arrows," not elsewhere in A.S., græghama = "mailcoat"; cf. Beowulf, v. 334, græge syrcan, Andreas, v. 129, guðsearo gullon, "The arrows are whistling, the mail-coat is rattling."

(2) fugelas = "birds of carrion," harbingers of slaughter, as often in A.S. poetry ; græghama = "wolf"; of. Exeter Gnomic Verses, 151, wulf se græga, Brunanburh, v. 64, etc.

The latter rendering is more in character.

8. pes, idiomatic usage; cf. Exodus, v. 430, peos geomre lyft, etc. (Klaeber, Archiv f. n. S. cxv. 181).

9. waðol; cf. perhaps MHG. wadel, "wandering," "erratic"; see Chambers, Beowulf, p. 159.

10. folces nid in the sense of folcgefeoht, folcgevinn.

12. Hickes, habbað eovre landa, hie geab on ellen, emended to habbay eowre hlencan, hicgeap on ellen on the analogy of Elene, v. 218: habban heora hlencan, hycgan on ellen; cf. Bugge, P.B.B. xII. 23.

hicgea $p$ mellen; cf. Atlamál, xLvi, hugbi a harbrǽ $b i$ and the Homeric $\mu \nu \hat{\eta} \sigma a \sigma \theta \epsilon \delta \dot{\theta} \theta \dot{\delta} v i \delta \circ \mathrm{s} \alpha \kappa \hat{\eta} s$ (Iliad, vr. 112).

13. windað on orde; cf. Genesis, , 417 :

$$
\text { pert he mid feđerhoman fleogan meahte }
$$

The initial letter of windad is slightly different in form from the oustomary $w$ of Hickes. Hence Rieger (Z.f.d.A. xIVIII. 9) and Klaeber (E. St. xxxrx. 428) read pindad = tumescere, "show your temper"; the alliteration would then fall on orde, onmode. But cf. $\nabla .27$, wreccea (H. wrecten), where the identical form of $w$ is found and initial $b$ is out of the question. Moreover Hickes represents capital $b$ by $\boxplus$, even where the Mss. have $b$ : cf. Metra of Boethius, Iv. 11, $12 \mathrm{ff}$. in Thesaurus, 1. 185 and Grein. Wülker, mI. $7 \mathrm{ff}$.

D. R. P. 
14, I5 Đa aras mænig goldhladen ðegn, gyrde hine his swurde;

ða to dura eodon

drihtlice cempan,

Sigefero and Eaha hyra sword getugon

and æt oprum durum Ordlaf and Guplaf

and Hengest sylf hwearf him on laste.

Đa gyt Garulf Guðere styrode

oæt he swa freolic feorh forman sipe

to Jære healle durum hyrsta ne bære

nu hyt nipa heard anyman wolde.

ac he frægn ofer eal[le] undearninga,

25 deormod hælep, hwa pa duru heolde.

"Sigefer $\gamma$ is min nama (cwep he), ic eom Secgena leod,

wrecce $a$ wide cuð; fæla ic weana gebad, heordra hilda. Đe is gyt her witod swæper $\delta u$ sylf to me secean wylle."

$30 \quad$ Đa wæs on healle wælslihta gehlyn; sceolde cellod bord cenum on handa

22. H. baeran. 24. H. eal. 27. H. wrecten, weuna. 31. H. sceolde Celaes borð genumon handa.

14. Apparently there is a half-verse missing here and Sievers $(Z, f . d . P h$. xxIx. $563 \mathrm{ff}$.$) , regarding goldhladen begn as unmetrical, would emend to$ goldhladen gumpegn; of. be Monna Cræfte, v. 83. Hence Holthausen (Z.f.d.Ph. xxxvIr. 123) proposes

\section{$Ð a$ aras [of ræste rumheort] mænig goldhladen [gum]pegn.}

But, as in Hildebrand, I prefer to print the ms. as prose.

17. Eaha: this form with intervocalic $h$ is declared impossible by Möller (ae. Volksepos, p. 86), who would emend to Eawa (the name of Penda's brother in Chronicle, 716 A, 757 A); but cf. Echha in Liber Vitae, 94, 96 (Sweet, O.E.T. p. $155 \mathrm{ff}$.), Aehcha in a charter of Wihtred, K. of Kent (O.E.T. p. 428) and Acha (fem.) in Bede, H.E. III. 6.

18. durum, pl. for sing., as regularly in $\mathrm{ON}$. dyrr.

Ordlaf and Guplaf; cf. the Oslaf and GuJlaf, who appear as Hnæf's avengers in Beowulf, v. $1148 \mathrm{ff}$. The names Oddleivus and Gunnleivus are also found in Arngrim Jónsson's epitome of the lost Skjöldunga saga, c. rv.; cf. Chadwick, O.E.N. p. 52.

19. Hengest. Chadwick (O.E.N. p. 52) has shown that there is some reason for identifying this Hengest with the conqueror of Kent, the only other person who bears the name.

$20 \mathrm{ff}$. It is just possible that Hickes' reading (with the emendation of he to he[0]) may be taken.

" Meanwhile Garulf (a Frisian) was taunting the warlike band (Hengest's men), saying that such noble souls as they should not bear their armour to the hall-door at the first onset, now that a bold warrior (Garulf himself) was bent on spoliation."

[But 
Then up rose many a knight bedecked with gold and buckled his sword about him. The lordly champions strode to the door; Sigeferth and Eaha drew their swords, and to the other door went Ordlaf and Guthlaf, and Hengest himself followed in their wake.

Meanwhile Guthhere was urging Garulf that he, whose life was so precious, should not bear his armour to the door of the hall at the first onset now that a fierce warrior was bent on spoliation. But he like a gallant hero demanded loudly above all the din of battle who it was that held the door. "Sigeferth is my name," said he. "I am prince of the Secgan, known as a rover far and wide. Many a hardship, many a fierce battle have I endured. Yet to thee is either lot assured that thou wilt seek at my hands."

Then there was the crash of deadly blows within the hall; the beaked shield in the heroes' hand must needs

But for my own part I am inclined to favour a more radical purge on the lines of Klaeber (E. St. xxxIx. 307, adopted by Chambers):

ba gyt Garulfe Guðere styrde, etc.

"Meanwhile Guthhere was restraining Garulf (his nephew; cf. Hagano and Patavrid in Waltharius, v. 846; Hildebrand and Wolfhart in Nibelungenlied, str. $2208 \mathrm{ff}$.), saying that he, whose life was so precious, should not bear his armour to the hall-door at the first onset, now that so bold a warrior (Sigeferth) was bent on spoliation; but he (Garulf)...."

23. hyt, loose usage for hie (hyrsta); cf. Beowulf, v. 1705 (Klaeber, Anglia, xxvirr. 456).

24. Hickes, eal. Trautmann (B.B. vir. 44) emends to ealle on metrical grounds; cf. Beowulf, v. 2899 : sægde ofer ealle, and Daniel, v. 528: frægn ofer ealle

Swiðmod cyning hwæt pæt swefen bode.

26. Sigeferp, Secgena leod, doubtless the Sxferd who ruled the Sycgan in Widsith, v. 31. For the confusion of Sæ- and Sige-, cf. Sæberht, K. of the East Saxons, who appears as Saberchtus or Saeberchtus in the text of Bede, but as Sigberchtus in certain sss. of the Chronologicai Summary (Plummer, Baedae Opera Historica Ir. 353); cf. Chambers, Widsith, p. 199.

Uhland (Germ. Ir. $357 \mathrm{ff}$.) and Golther (Germ. xxxir. 474-5) identify this Sigeferp with Sigurd the Volsung, but their views have met with little support.

(cwep he): the only instance in AS. of the parenthetical "said he," so common in Hildebrand and the Heliand.

30. Cf. Saxo, Bk ir. (Holder, p. 65):

Iam curia bellis

Concutitur diroque strepunt certamine portae.

31, perhaps the greatest crux in AS. poetry. Hickes is quite un. intelligible; Grein (Beowulf, p. 76) emends to sceolde cellod bord cenum on handa, banhelm berstan,

comparing Maldon, $\mathbf{2}$. 283, clufon cellod bord, where cellod probably means " beaked" (Bosworth-Toller; cf. Epinal Gloss. 862 : rostrum=neb vel scipes celae), no unsuitable epithet for an Anglo-Saxon shield. There are many 
banhelm berstan; buruhðelu dynede, oð æt ઈære guðe Garulf gecrang ealra ærest eorðbuendra,

35 Gurlafes sunu; ymbe hyne godra fæla, thwearflacra hraer. $\dagger$ Hræfen wandrode sweart and sealobrun, swurdleoma stod, swylce eal Finn[e]sburuh fyrenu wære. Ne gefrægn ic næfre wurplicor æt wera hilde sixtig sigebeorna sel gebærann, ne næfre swanas hwitne medo sel forgyldan, ðonne Hnæfe guldan his hægstealdas. Hig fuhton fif dagas, swa hyra nan ne feol drihtgesiða, ac hig ða duru heoldon.

45 Đa gewat him wund hæleð on wæg gangan, sæde pæt his byrne abrocen wære, heresceorpum hror, and eac wæs his helm oyrl. Đa hine sona frægn folces hyrde hu ta wigend hyra wunda genæson,

50 оððе hwæper ซæra hyssa.......
38. H. Finnsburuh.
41. H. swa noc.
44. H. dura.

other suggestions [Trautmann, B.B. vir. 46, cyllod, "covered with leather," from cyll, "a leather pouch"; Jellinek, P.B.B. xv. 431, celed; cf. Beowulf, v. 3022, gar morgenceald; Holthausen ceorlæs (collect. sg.), later clæne, etc.]; but Grein still holds the field.

banhelm may be taken as a kenning for shield, either:

(1) bănhelm= munimentum adversus occisores (Sprachschatz) or

(2) $b \bar{a}$ hhelm $=b \bar{a} n h u s-h e l m$, "protection for the frame," though in similar compounds ban=ON. bein; e.g. banbeorgas, banryft=ocreae. In either case berstan would be intransitive.

"The beaked shield...must needs be shattered."

Bugge, however (P.B.B. xir. 26) would emend to bar-helm, "boarhelmet," and take berstan as transitive, so in Riddle v. 8 , and often in Middle English.

"The beaked shield...must needs shatter the boar-helmet"; cf. Tacitus, Agricola, c. xxxvi.: Igitur et Batavi miscere ictus, ferire umbonibus, ora foedare; and Waltharius, v. 195 :

Sternitur et quaedam pars duro umbone virorum.

Unfortunately $b \bar{a} r$ does not occur in Anglo-Saxon poetry. But cannot bänhelm be retained in the sense of "helmet decorated with bones" (horns); cf. the epithets applied to Heorot in Beowulf, v. 704, hornreced, v. 780, banfah? This view is quite unobjectionable on philological grounds and is supported by archaeological evidence. Of course there are no such belmets in existence from the Germanic area. Helmets of any description are comparatively rare and, decorated with horns, are found only in representation; e.g. alongside boar-helmets on the bronze plates from Torslunda, Öland (Stjerna, Essays on Beowulf, p. 8); on the silver disc from Neuwied (Althof, Waltharii Poesis, II. 398); on the Golden Horn of Gallehus and the Gundestrup bowl (Müller, Nordische Altertumskunde, II. 155, 165). For 
shatter the horned helm. The castle floor reechoed, till in the fray fell Garulf, son of Guthlaf, first of dwellers upon earth, and many a gallant warrior about him;...... The raven hovered dismal with its dusky plumage; the gleam of swords flashed forth as though all Finn's castle were aflame.

Never have I heard of sixty warriors flushed with victory who bore themselves more gallantly nor more honourably in mortal conflict, nor squires who paid a better recompense for shining mead than did his retinue to Hnaef. Five days they fought in such a wise that no man fell out of that knightly band; but still they held the door.

Then departed a wounded hero limping from the fray; he said that his mailcoat, armour of proof, was shattered and pierced likewise was his helm. Him straightway asked the keeper of the host how those warriors survived their wounds, or which of the heroes......

non-Germanic, Mycenaean, Macedonian, Celtic, instances, cf. DarembergSaglio, Ir. 1438 ff., 8.v. galea.

36. Hickes' hwearfiacra hraer is corrupt, and none of the many emendations (Grundtrig, hwearflicra hræw ; Bugge, P.B.B. xIr. 27: hwearf [f]lacra hræw) are at all convincing. Those editors who see a verb in hraer are perhaps nearer the mark (Jellinek, P.B.B. xv. 431, hwearf ladra hreas) ; and Holthausen's hwearf [b]lacra hreas, " a company of pale ones fell," is supported by Beowulf, จ. 2488, hreas [hilde]blac.

38. Hickes, Finnsburuh, an impossible form in AS.

41. Grein (Beowulf, p. 76) emends Hickes to ne næfre swanas swetne medo sel forgyldan. Swanas is obviously correct; but since the metre is corrupt again, there is no point in altering hwitne.

44. duru: probably Hickes misread $u$ for $a$ in the Ms., as in v. 3 eastun, v. 27 weuna.

47. heresceorpum hror. Thorpe emends to heresceorp unhror, "his armour useless," though it is doubtful whether unhror can bear this meaning; cf. however, Chambers, Beowulf, p. 162. But the as. reading can be translated "strong as armour" (Bosworth-Toller).

48. folces hyrde: Finn; cf. the common Homeric expression $\pi$ oi $\mu \epsilon \nu a$ $\lambda \alpha \hat{\omega} \nu$, "shepherd of the host," applied especially to Agamemnon. 


\title{
DEOR
}

\author{
Weland thimbe wurman $\nmid$ wræces cunnade, \\ anhydig eorl earfopa dreag, \\ hæfde him to gesippe sorge ond longap, \\ wintercealde wræce; wean oft onfond,
}

1. Weland, the most celebrated smith of old Teutonio legend, mentioned over and over again in the literature of the middle ages. The references, English, German, Scandinavian and French, are collected by Maurus, Die Wielandsage, pp. 7-57 (Münchener Beiträge, xxv., Erlangen, 1902); cf. especially King Alfred's Translation of the Metra of Boethins, x. 33:

Hwær sint nu pæs wisan Welandes ban
pæs goldsmiðes, pe wæs geo mærost;

and pirriks saga, c. 69 (Bertelsen, II. 105):

Velent er sva frægr um alla norðrhalfo heimsins at sva byckiaz allir menn mega mest lofa hans hagleic at hveria ba smið er betr er gor en annat smiði, at sa er Volundr at hagleic er gort hevir.

Hence any weapon of especial excellence was ascribed to Weland; cf. Beowulf, v. 455, Welandes geweorc (of B.'s corselet); Waldhere, A 2 (of the sword Mimming); Waltharius, v. 965, Wielandia fabrica (of a mailcoat), etc.

The story mentioned here is found at length in the Old Norse Vqlundar$k v i b a$, one of the earliest of the Edda poems.

Briefly summarised, the story runs as follows: Vølundr, a mysterious smith, is surprised by Nípopr, king of the Niarar, and robbed of a great treasure, including a (magic?) ring. The ring is given by Nipopr to his daughter Bopvildr and the smith hamstrung to prevent reprisals. Forced to labour for the king, he seeks an opportunity for revenge, which soon presents itself. Visited in secret by Nipopr's sons, he slays them both and makes of their bones utensils for the royal table. In the meantime Bopvildr has broken her ring and, fearing her father's wrath, she brings it to the smithy for repair. The smith receives her amiably and offers her wine to drink; but the draught is drugged and Volundr works his will upon the sleeping princess. Once more in possession of the ring, he regains his magic power and flies away, first announcing what has happened to the king.

An expanded version of the Vølundr story, owing something to German influence, is found in piðriks saga, c. $57 \mathrm{ff}$. (Bertelsen, 1. $73 \mathrm{ff}$.). There Velent is affiliated to the giant Vadi, the Wada of Widsith, whereas in Vølundarkvipa itself he is called visi alfa, "prince of the elves," in the prose introduction "son of the king of the Finns." Moreover the son of Bopvildr and Vølundr, vaguely hinted at in Vølundarkvipa, plays an important part in piðriks saga. He is Viðga, the Widia.Wudga of Widsith, 


\section{DEOR}

Weland, the steadfast warrior, had experience of persecution; he suffered hardship. As boon companions he had grief and yearning, misery in the cold of winter. He fell on

v. 130, and Waldhere, B 4, the famous Wittich of the MHG. Dietrich cycle. This person seems to be identical with the Gothic hero Vidigoia of Jordanes, cc. v. and xxxrv. Possibly there was something mysterious about the parentage of this Vidigoia; he may have been the offspring of a Gothic princess and a bondsmith [Chadwick, H.A. p. 135], and since smiths were generally regarded as uncanny people, a folk-tale-of. the Gascon Pieds d'Or, edited by Bladé, Contes Populaires de Gascogne, I. 126-147 (Paris, 1886)may have been superimposed upon the original heroio story.

The second and third words are quite unintelligible; they are usually printed him be wurman, and a host of suggestions, probable and improbable, are collected in Grein-Wülker, I. $278 \mathrm{n}$. Wurman might conceivably be a blundered place or tribal name. Tupper for instance (Mod. Phil. rx. 266) suggests that we should keep the ms. reading and translate "in Wermaland" (the S. Swedish district of Värmland, which is associated in the Heimskringla, Olafs saga Helga, cc. 77, 181, with the neighbouring Nerike and West Götaland; see v. 14 n.).

4. wintercealde; twice elsewhere in AS., Andreas, v. 1265, and Ridd. v. 7, where it seems to mean "in the cold of winter"; of. pirriks saga, c. 73 (ed. Bertelsen, 1. 117) :

Velent mælir at beir skulo ganga ofgir til smiðionnar begar snior væri nyfallin. En sveinarnir hirða aldregi hvart beir ganga ofgir eða rettir, en betta hefir um vetrinn veret. Oc ba samo nott eptir fell snior.

In English tradition Weland is connected with a famous cromlech known as Wayland Smith near Ashdown in Berkshire; cf. a letter from Francis Wise to Dr Mead, printed in Warton's History of English Poetry from the Twelfth to the Close of the Sixteenth Century (ed. by W. C. Hazlitt, London, 1871), 1. $63 \mathrm{ff}$. :

"All the account which the country people are able to give of it is: at this place lived formerly an invisible Smith, and if a traveller's horse had left a shoe upon the road, he had no more to do than to bring the horse to this place with a piece of money, and leaving both there for some little time he might come again and find the money gone but the horse new shoed."

A similar story, told of the volcanic isle of Strongyle, is found in the Scholia to Apollonius Rhodius, Argonautica, Ir. 761, and silent barter of this kind still existed among the Veddahs of Ceylon in the days of Knox (1681); of. Seligman, The Veddahs, p. 6 ff. (Cambridge, 1911).

For the smith in tradition, see Schrader, Sprachvergleichung u. Urgeschichte $e_{3}$, 1r. 13-28 (Jena, 1907), and for the Weland story generally Jiriczek, Deutsche Heldensagen, pp. 1-54 (Strassburg, 1898), and Clarke, Sidelights on Teutonic History, pp. 201-8 (Cambridge, 1911). 
5 sippan hine Niðhad on swoncre seonobende pæs ofereode; Beadohilde ne wæs on sefan swa sar pæt heo eacen wæs; priste gepencan, pæs ofereode; We -pæt Mæðhilde

I5 wurdon grundlease hu ymb prt sceolde. pisses swa mæg.

nede legde, on syllan monn. pisses swa mæg. hyre bropra deap swa hyre sylfre ping, ongieten hæfde æfre ne meahte monge gefrugnon Geates frige,

\section{MS. mæð hilde.}

5. on should be included in the first half-line. An exactly parallel expression is found in Christ and Satan, v. 539:

$$
\begin{aligned}
& \text { pec gelegdon on laðne bend } \\
& \text { hæðene mid hondum. }
\end{aligned}
$$

6. seonobende; for the use of sinews as ropes, cf. Judges xvi. 7, mid rapum of sinum geworhte (A.V. "with seven green withs that were never dried").

For the whole passage, cf. Vølundarkvipa, xrv.:

Vølundr kvap:

$$
\begin{aligned}
& \text { Vissi ser à hqndum hqfgar naubir } \\
& \text { En á fotum fjQtur of spentan. }
\end{aligned}
$$

$$
\text { “Hverir 'u jefrar beirs a logku }
$$

Several editors (see Grein-Wülker, I. $278 \mathrm{n}$.) have wished to read into the stanza the story of the maiming of Vølundr ; ef. the prose between strophes XVIIr. and XIX. of Vkv.: Svá var gQrt at skornar váru sinar i knesfótum ok settr $i$ holm eiutu.

They therefore emend seonobende to seonobenne, "wound to sinew," and translate "after Nithhad had laid him in bonds (and laid) a supple sinewwound on a better man." But such emendation is quite unnecessary.

7. ofereode, impersonal with gen. of respect; of. Shipley, The Genitive case in Anglo-Saxon Poetry (Baltimore, 1903), pp. 18, 50 : Brandl's rendering (P.G.2 Ir. 975), " das ging vorüber, dieses (gehe vorüber) wie es kann," seems unnecessarily strained.

8. Beadohilde, the daughter of Nithad; her brothers had been slain and she herself outraged by Weland, as can be seen from the ON. Vølundarkvipa and piðriks saga, c. 78 , especially $\nabla$ ølundarkvipa xxxvin. : $N u$ gengr BQpvildr barni aukin. Elsewhere her name occurs only as the Buodell of the Danish ballad, Kong Diderik og hans Kæmper, B 15 (Grundtvig, Danmarks Gamle Folkeviser, 1. 100, Kjøbenhavn, 1853):

Werlandt heder min fader,

war en smedt well skфn:

Buodell hede min moder,

en koning-dather wen.

The son of Beadohild and Weland was the Widia (Wudga) of Widsith, v. 124-130, and Waldhere B, v. 4-10, the Viłga of pirriks saga, and the Wittich of the Dietrich cycle in MHG. literature. He was undoubtedly the Vidigoia, "the bravest of the Goths, who fell by the treachery of the Sarmatians," and was celebrated by his people in heroic poetry; cf. Jordanes, de Origine Actibusque Getarum, cc. v., xxxiv. 
evil days after Nithhad had laid fetters upon him, supple bonds of sinew on a nobler man.

That was surmounted; so can this be.

On Beadohild's mind her brothers' death preyed far less sorely than her own condition, when she clearly perceived that she was with child; she could not bear to think on what must happen.

That was surmounted; so can this be.

Many of us have heard that the Geat's affection for

14. MS. we bæt mæð hilde monge gefrugnon.

A number of editors retain this reading and connect mæ (elsewhere unknown in AS.) with the ON. meiða, translating "Many of us have heard of Hild's violation." They cannot agree, however, upon the identity of the lady. Gummere (O.E.E. p. 185) suggests Odila, the wife of Sifka, outraged by Erminrik in piðriks saga, c. 276 (Bertelsen, Ir. 158 ff.). Perhaps the most plausible of these explanations is that put forward by Frederick Tupper, Jr (Mod. Phil. Ix. $265 \mathrm{ff}$.) ; he suggests that this, like the preceding stanzas, refers to the Weland story. The Geat he identifies with Niðhad (cf. Vkv. Ix., Níbobr Niara drottin=" "lord of Nerike," a part of the Swedish Götaland in medieval times), the Hild with Beadohild. With v. 16 he compares Vkv. xxxi11. :

$$
\begin{aligned}
& \text { Vaki ek ofvalt viljalauss, } \\
& \text { sofna ek minst }
\end{aligned}
$$

But elsewhere in AS. frige is used for sexual rather than parental love. Besides the story of Nirhad and Widia, the son of Beadohild and Weland (Niduda? and Vidigois in Jordanes) is almost certainly of Gothic origin and little likely to be connected with Sweden (as in Vkv.) in a poem so early as Deor.

With less probability Lawrence (MIod. Phil. Ix. $29 \mathrm{ff}$.) argues that it deals with the love of Hild and Heðinn, comparing particularly the version found in Saxo, Bk v.

But the case is far from proven, and it is safer to regard this stanza as alluding to one of those stories, familiar enough to an Anglo-Saxon audience, which have not come down to us. Klaeber (Anglia, Beiblatt, xvIr. 283 ff.) regards mæð hilde as the Dat. of a compound name, Mæðhilde. For the use of MæX- as the first element of a personal name there is at least one parallel in the MæYhelm of Liber Vitae, 96 (Sweet, O.E.T. p. 156). It is perhaps derived by haplology from Mæðelhild, for the first element of which cf. the Frankish Mallobaudes (Schönfeld, Wörterbuch der Germanischen Personen. und Volkernamen, p. 159).

The name Geat does occur at the head of the West-Saxon and Bernician genealogies, and in Old Norse literature there are a number of kings called Gautr (Chadwick, O.E.N. p. 270) ; but there is nothing to connect this Geat with them. It should be taken therefore as a national rather than a personal name; Beowulf is spoken of as Geat in vv. 1715, 1792.

The Scandinavian story of the god Freyr's love for the giantess Geryr (found in Skírnismál, xLIII. :

$$
\begin{aligned}
& \text { LQng es nott, langar 'u tvær, } \\
& \text { hve of preyjak priar? } \\
& \text { Opt mér mónupr minni pótti } \\
& \text { an sja hýnǵtt holf; }
\end{aligned}
$$

and Gylfaginning, c. xxxv1r. : ekki svaf hann, ekki drakk hann; engi porði at krefja hann málsins) is interesting as a parallel but nothing more. 
pret him seo sorglufu pæs ofereode; pisses swa mæg.

Đeodric ahte pritig wintra

Mæringa burg; pæt wæs monigum cup.

pæs ofereode; pisses swa mæg.

We geascodon Eormanrices

wylfenne gepoht; ahte wide folc

Gotena rices; pæt wæs grim cyning.

Sæt secg monig sorgum gebunden,

25 wean on wenan,

pæt pæs cynerices

wyscte geneahhe

pæs ofereode; ofercumen wære. pisses swa mæg.

16. MS. $h i$.

18. Đeodric. With the notable exception of Wilhelm Grimm most authorities have identified Dietrich von Bern, the Theodoric of legend, with the historical king of the Ostrogoths, who conquered Italy from Odovacar and ruled it with great success from 493 to 527. It is certain that he was so identified in Anglo-Saxon literature; for the passages bæt wæs Theodoricus se cyning pone we nemnap peodric in the Old English Martyrology (p. 84, ed. Herzfeld, E.E.T.S.) and se peodric wæs Amulinga in King Alfred's Old English Translation of Boethius (p. 7, ed. Sedgefield, Oxford, 1899) equate the historical Theodoric with the hero of popular tradition. Yet there are certain striking differences; for the most notable features of the MHG. Dietrich story, found already in Hildebrand, are the thirty years of exile at the Hunnish court and the loss of almost all his knights-which find no counterpart in the life of the historical Theodoric. It seems most probable therefore that the Dietrich of tradition has been credited with adventures, which belong more properly to some older Gothic hero; perhaps his father, Theodemer, whose name indeed is found in one us. of the Older Edda (e.g. pjobmár of Guprúnarkviba, III. 3), perhaps the Gensimundus toto orbe cantabilis of Cassiodorus ; cf. Chadwick, Heroic Age, p. 62.

19. Mæringa burg. A most striking parallel is to be found on the 10th century Runic stone from Rök in Östergötland, Sweden; cf. Bugge, Antiqvarisk Tidskrift för Sverige, v. $1 \mathrm{ff}$., and Stephens, Handbook of the Old Northern Runic Monuments, p. 32 ff. (London, 1884):

$$
\begin{aligned}
& \text { raip [p]iauriks hin purmupi } \\
& \text { stilis flutna [a] strantu hraipmarar. } \\
& \text { sitir nu karuR a kuta sinum } \\
& \text { skialti ub fatlapr skati marika. }
\end{aligned}
$$

"Theodoric the bold was riding,

prince of warriors, on the shores of the Gothic sea [Adriatic]. $\mathrm{He}$ is sitting armed on his steed, decked with a shield, the lord of the Mæringas."

This strophe is supposed to be a description of the equestrian statue of M. Aurelius, ascribed to Theodoric by the barbarians, which stood at Ravenna till removed by Charlemagne to Aachen in 809; cf. Torp, Ark.f.n.F. XxIx. $345 \mathrm{ff}$.

Mæringas, evidently a name applied to the Ostrogoths; elsewhere we find in the Regensburg Gloss Gothi=Meranare, and in the Latin prologue to Notker's OHG. translation of Boethins Theodoric is called rex Mergothorum et Ostrogothorum.

For the connection between Dietrich and the Tyrolese Meran in MHG. 
Maethbild passed all bounds, that his hapless love completely robbed him of his sleep.

That was surmounted; so can this be.

Theodric ruled for thirty years the fortress of the Maeringas; that has become a matter of common knowledge. That was surmounted; so can this be.

We have learned of Eormanric's ferocious disposition; he held dominion far and wide in the realm of the Goths. A cruel king was he. Many a man sat in the toils of care, anticipating trouble and continually praying for the downfall of his sovereignty.

\section{That was surmounted; so can this be.}

literature, cf. Heinzel, $\ddot{U} b e r$ die ostgotische Heldensage, pp. 9 ff.' (Wien, 1889); Jiriczek, D.H.S. I. 119 ff.

21. Eormanrices. According to his contemporary, Ammianus Marcellinus, xxxr. 3. 1, Ermenrichus was a great king of the Goths, his empire stretching from the Baltic to the Euxine, who perished by his own hand, despairing of resistance to the Huns, c. 375. After Theodoric he was the most celebrated in tradition of the Gothic kings; but he bears a most sinister character throughout. Widsith, v. 88 ff., credits him with generosity, but styles him wrap wærloga, an epithet elsewhere applied to the Devil, and Beowulf, v. 1200, speaks of his searoniðas (murderous wiles); cf. too the Quedlinburg Annals : astutior in dolo, largior in dono. Already in the 6th century Jordanes, c. xxIV., relates that he was attacked and disabled by the kinsmen of Sunilda, whom he had torn asunder by wild horses, pro mariti fraudulento discessu, whatever that may mean.

There are three main elements in the later story of Eormanric (Jiriczek, D.H.S. 1. 99). 1. The slaying of Swanhild and the vengeance taken by her brothers. 2. The death of his son. 3. The murder of the Harlungs (the Herelingas, Emerca and Fridla, of Widsith, v. 112); his persecution of Dietrich is peculiar to the German version.

From the 9th century at least the story developed on independent lines in Germany and Scandinavia. The Northern authorities, Bragi's Ragnarsdrápa, the Hamrismál, the Prose Edda and the Volsunga Saga (with the exception of Saxo, who only knows the Nibelung story from Low German sources; cf. Bk xIII., p. 427, notissimam Grimilde erga fratres perfidiam) connect it with their greatest hero Sigurd Fáfnisbani ; Swanhild, daughter of Sigurd and Guðrun, is avenged by her brothers Hamðir and Sqrli, Jqrmunrekk's hands and feet being cut off. In Germany, on the other hand, Eormanric is attracted into the Dietrich cycle; Dietrich is represented as his nephew, though we know from historical sources that he was born some eighty years after the former's death. In Middle High German literature (Dietrich's Flncht, etc.), as also in piðriks saga, Eormanric is the wicked uncle of tradition; he compasses the death of his two nephews, the Harlungs, Dietrich the third he deprives of his kingdom. In the latter role he has evidently displaced Odovacar; cf. Hildebrand, v. 18.

For an exhaustive treatment of Eormanric in tradition, see Jiriczek, D.H.S. r. 55-118; Clarke, Sidelights on Teutonic History, pp. 232 ff.; Chambers, Widsith, pp. 15-36.

22. wylfenne, "wolfish," "ferocious"; cf. Heliand, v. 5059 : habdiun im hugi wulto (of the Jews). 
Siteð sorgcearig, sælum bedæled on sefan sweorcer; sylfum pincer

30 pæt sy endeleas earfoða dæl. Mæg ponne gepencan, pæt geond pas woruld witig dryhten wendep geneahhe, eorle monegum are gesceawað, wislicne blæd, sumum weana dæl.

35 prt ic bi me sylfum secgan wille, pæt ic hwile wæs Heodeninga scop, dryhtne dyre; me wæs Deor noma.

Ahte ic fela wintra folgar tilne, holdne hlaford, op pæt Heorrenda nu,

40 leoðcræftig monn, londryht gepah, pæt me eorla hleo ær gesealde. pæs ofereode; pisses swa mæg.

30. MS. earfoda.

31. Cf. Wanderer, v. 58 :

For bon ic gepencan ne mæg geond pas woruld, for hwan modsefa min ne gesweorce ponne ic eorla lif eal geondpence;

a characteristic mood in Anglo-Saxon literature.

36. Heodeninga 8cop: Heodeningas ="Heoden and his men," cf. ON. Hjaðningar in the kenning Hjaðninga veðr: "battle" (Skaldsk. c. xuIx.), and MHG. Hegelingas (the form should be Hetelingas, but it has been influenced by certain Bavarian place-names; cf. Jiriczek, Northern HeroLegends, p. 134) of the Austrian poem Kudrun.

Herinn and Hogni-Hagena weold Holmrygum, Heoden Glommum of Widsith, v. 21 -and the story of their everlasting conflict are known from all parts and all ages of the Scandinavian world, in the Ragnarsdrápa of Bragi Boddason, the earliest of Norwegian skalds, in the Háttalykill of Rognvaldr, Jarl of the Orkneys (12th cent.), in the Icelandic Prose Edda of Snorri Sturlason and Sqrlapattr, in the Faroese Sjurðar Kvæði-where, curiously enough, Hogni is confused with his namesake of the Nibelung story -and in a Shetland ballad of 1774 from the isle of Foula. The betterknown of these versions are collected and translated by Chambers, Widsith, p. $100 \mathrm{ff}$. In Kudrun, however, Hetele and Hagen are reconciled; cf. Panzer, Hilde-Gudrun, passim (Halle, 1901). 
He who is anxious and distressed sits bereft of joy, with gloomy thoughts in his heart. Suffering, he deems, will ever be his lot. Still he can reflect that the wise Lord follows very different courses throughout the world; to many a man he gives honour and abiding prosperity, yet nought but misery to some.

Of myself I will say this much, that once I was minstrel of the Heodeningas, my master's favourite. My name was Deor. For many years I had a goodly office and a generous lord, till now Heorrenda, a skilful bard, has received the estate which the protector of warriors gave to me in days gone by.

That was surmounted; so can this be.

a7. Deor. The name Deor (in the form Diar) occurs in a Kentish charter of 859 ; cf. Sweet, O.E.T. p. 450 . It is also found on a coin of Coenwulf of Mercia (796-822); and Aethelwulf of Wessex had a moneyer of that name at Canterbury; cf. Grüber and Keary, Catalogue of English Coins in the B.M., Anglo-Saxon series, I. 34, Ir. 9 ff. (London, 1887-93).

39. Heorrenda, like the Horant of Kudrun, is Heoden's minstrel. In the Prose Edda (Skaldks. c. xLIx.) and Sorlapáttr, however, Hjarrandi is become the father of Hexinn, though a tradition of the poet may have survived in the Hjarrandaljó $\delta$ mentioned in Bósa saga, c. XIr. (F.A.S. III. 264).

40. londryht; as in Beowulf, v. 2886 :

$$
\text { pære mægburge } \quad \begin{aligned}
& \text { londrihtes mot } \\
& \text { monna æghwylc }
\end{aligned}
$$

seems to mean an "estate" (or the rights over one), granted by the king and revocable at his pleasure; cf. Widsith, $\nabla .95$ : 


\section{HILDEBRAND}

Ik gihorta dat seggen

đat sih urhettun $\hat{x}$ non muotin, Hildibrant enti Hađubrant, untar heriun tuem. Sunufatarungo iro saro rihtun,

5 garutun se iro guđhamun, gurtun sih iro suert ana, helidos ubar [ $h]$ ringa; do sie to dero hiltiu ritun. Hiltibrant gimahalta, (Heribrantes sunu,) her uuas heroro man,

ferahes frotoro, her fragen gistuont

fohem uuortum, $[h]$ wer sin fater wari I0, II fireo in folche, "eddo $[h]$ welihhes cnuosles du sis?

ibu du mi enan sages, ik mi de odre uuet, chind, in chunincriche: chud ist mir al irmindeot." Hadubrant gimahalta, Hiltibrantes sunu :

I5 "Đat sagetun mir usere liuti, alte anti frote, dea érhina warun,
3. MS. Hildibraht.
9. MS. wer,
6. MS. ringa.
11. MS. welihhes.
7. MS. Hiltibraht. 13. MS. min.

1. Ik gihorta dat seggen, a regular epio formula in the old Teutonic languages.

2. urhettun might be $\mathrm{N}$. pl. of a noun corresponding to AS. oretta, or the pret. pl. of a weak verb; cf. Goth. ushaitjan.

ænon, probably N. pl. of adjective; cf. Heliand, v. 13, ênon (Ms. enan).

muotin has been interpreted as the imperfect subj. of a verb corresponding to OS. motian, as the pret. pl. of muoen, " bemühen," "bedrängen" ; or as the G. sg. of a noun, for which however there appears to be no evidence in OHG. nor OS. But cf. Branne, Ahd. Lesebuch, pp. 180-1.

4. Sunufatarungo, a representative of a class of nouns-"dvandva compounds "- common in Sanskrit ; cf. OS. gisunfader, "father and sons" (Heliand, v. 1176): AS. suhtergefæderan, "uncle and nephew" (Beowulf, v. 1164), etc. It might conceivably be an old dual; otherwise it must be a G. pl. depending on heriun. Cf. Braune, p. 181. 


\section{HILDEBRAND}

I have heard it said that Hildebrand and Hadubrand challenged each other to single combat between the hosts. Father and son, they set their panoply aright and made their armour ready: the heroes girt their swords above their corselets when they rode to the fray.

Hildebrand spake, the son of Heribrand: he was the older man, the riper in years. He began to ask in a few brief words who was his father among mortal men, "or of what stock art thou? If, young warrior, thou wilt tell me the name of one man in the kingdom, I shall know the others of myself; for the whole race of men is known to me."

Then spake Hadubrand, the son of Hildebrand: "Our liegemen, full of years and wisdom, who lived in days gone

7. Heribrantes sunu extra metrical as in $\nabla \nabla .30,49,58$.

8. ferahes frotoro; cf. Maldon, $\nabla .317$ : ic eom frod feores.

9. fohem uuortum; cf. Beowulf, v. 2246: fea worda cwæð.

[h]wer sin fater wari

\section{fireo in folche;}

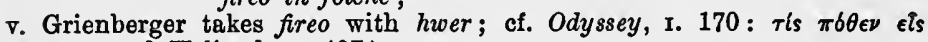
aे $\delta \rho \omega \omega \nu$; and Heliand, v. 4974 :

Fragôdun fiundo barn, hwilîkes he folkes wari:

"Ni bist thu, etc.,"

where the same abrupt transition from indirect to direct narrative is found.

But phrases such as mannô folc, helito folk are common in the Heliand.

With the whole passage Collitz (P.B.B. xxxvi. 366) compares the meeting of Diomedes and Glaucus in Iliad vi. $119 \mathrm{ff}$.

12. in chunincriche, probably to be taken with enan as above (Braune).

irmindeot, "the whole race of men." Irmin- was used as the first element of compounds (cf. AS. yrmenpeodum in the Menologium, v. 139, and eormencynnes in Beowulf, $\nabla .1957$; OS. irminthiod, frequently in the Heliand; ON. jormungrundr, "the whole earth") originally with the idea of universality (cf. Translatio S. Alexandri, c. IrI.: Irminsul, quod Latine dicitur universalis columna, quasi sustinens omnia), though afterwards this idea was often forgotten; cf. Widukind, Rerum Gestarum Saxonicarum Lib. 1. c. 12: Hirmin...; quo vocabulo ad laudem vel ad vituperationem usque hodie etiam ignorantes utimur quoted by Chadwick, Origin of the English Nation, pp. 226 ff.

16. alte anti frote; of. Otfrid, Ir. 12. 24: altêr inti fruâter, and Beowulf, จ. 2449 : eald ond infrod. 
dat Hiltibrant hætti min fater; ih heittu Hadubrant. Forn her ostar giweit, floh her Otachres nidhina miti Theotrihhe enti sinero degano filu.

2o Her furlaet in lante luttila sitten prut in bure barn unwahsan, arbeo laosa; he $[r]$ raet ostar hina. Det sid Detrihhe darba gistuontun fateres mines; dat uuas so friuntlaos man.

25 Her was Otachre ummet tirri, degano dechisto miti Deotrichhe.

Her was eo folches at ente; imo was eo fehta ti leop. Chud was her chonnem mannum.

$\mathrm{Ni}$ waniu ih iu lib habbe...."

" $+\mathrm{W}[e t] \mathrm{tu} \dagger$ irmingot" (quad Hildibrant) "obana ab heuane,

dat du neo dana halt mit sus sippan man dinc ni gileitos......"

Want her do ar arme wuntane bouga cheisuringu gitan, so imo se der chuning gap, 35 Huneo truhtin. "Đat ih dir it nu bi huldi gibu."

18. MS. gihweit.

22. MS. herad ostar hina dd.

24. MS. fatereres. After $26 \mathrm{MS}$. has darba gistontun, repeated mechanically from above, v. 23. 30. MS. W..tu, Hildibraht.

18. floh her Otachres nid; cf. Beowulf, จ. 1200: searoniðas fleah (Ms. fealh) Eormanrices.

It is significant that in Hildebrand, the earliest evidence for Dietrich's exile at the Hunnish court, his enemy is Otacher, Odoacer-Odovacar, the Scyrrian or Turcilingian leader of foederati, who in 476 deposed Romulus Augustulus, the last Emperor of the West, and reigned in Italy as Patrician till the invasion of Theodoric (489), by whom he was treacherously slain after the fall of Ravenna (493). In the MHG. epics (Dietrichs Flucht, etc.) Otacher's place is filled by Erminrek; cf. Deor, v. $21 \mathrm{n}$. An intermediate form of the story is found in the Quedlinburg-Würzburg Chronicles (MGH. SS. III. 31, vi. 23) and Ekkehard von Aura (MGH. SS. vi. $130 \mathrm{ff}$.), where Odovacar is the treacherous counsellor of Ermanric, corresponding to the Sibich of later authorities.

$20 \mathrm{ff}$. Perhaps the most satisfactory way of dealing with this much disputed passage (cf. Braune, p. 182) is to take prut with v. Grienberger as pruti (Gen.), "in his wife's bower." It can then be translated without difficulty as above.

21. barn unwahsan; cf. AS. Genesis, v. 2871 : bearn unweaxen.

23. us. $d \&$, which Braune and others regard as dittography for Det-rihhe: v. Grienberger compares with the inorganic pæt found in certain AS. charters. 
by, have told me that my father's name was Hildebrand. I am called Hadubrand. Long ago he departed towards the east: he fled from the hatred of Odovacar, away with Theodoric and many another of his knights. He left behind his hapless son, bereft of his heritage, a little child in his mother's borwer. But he rode away to the east. In after years Theodoric had need of my father; he had lost all his friends -he was exceeding wrathful with Odovacar. The most devoted knight by Theodoric's side, he was ever in the forefront of the host: he always loved the fray. He was famous among men of valour; but I deem he is no longer alive."

"I call to witness the Almighty God from heaven above," quoth Hildebrand, "that never hast thou sought the wager of battle with one so near of kin."

And with that he slipped from his arm the twisted rings wrought of imperial gold, which the king, even the lord of the Huns, had bestowed upon him. "This will I give to thee in earnest of good faith."

24. dat uuas so friuntlaos man, a figure of speech common in AS. and OS.; cf. Beowulf, v. 11: pæt wæs god cyning, etc. It refers to Theodoric rather than to Hildebrand; cf. the prose at the beginning of Guprúnarkvipa hin forna: pjóðrekr konungr var með Atla ok hafði bar látit flesta alla menn sina; Klage, vv. $2061 \mathrm{ff}$., and Nibelungenlied, str. $2256 \mathrm{ff}$.

25. ummet tirri; cf. Aasen, Norsk Ordbog, p. 808 ${ }^{\mathrm{b}}$ (Christiania, 1873); terren (tirren) : hidsig, vred, opirret, "hot-headed," "angry," "exasperated" (Kögel).

26. dechisto, generally taken as the superlative of an adj. corresponding to ON. bekkr, "tractable," "obedient." Kögel (Geschichte der deutschen Litteratur I. 1. 219) emends to dehtisto; cf. OHG. kideht: devotus. In any case cf. piðriks saga, c. 15 (Bertelsen, r. 34):

En sva mikit ann hvar beirra odrumm ath einguir karlmenn hafa meira vnnazt eptir bvi sem David kongur ok Jonathas.

27. folches at ente: cf. AS. Riddle Lxxx. 8 : herges at ende.

30. $W[e t] t u$ (second and third letters illegible in Ms.). The twelve different renderings are collected in Braune, p. 183; perhaps the least difficult of these is Grein's wettu=OHG. weizzu, "ich mache wissen," "rufe zum Zeugen an."

obana ab heuane; cf. Heliand, v. 5799 : obana fon radure.

31. neo dana halt; $\mathrm{cf}$. Goth. Skeireins, Iv. $\mathrm{d}:$ ni be haldis (non idcirco), and Heliand, v. 2643 :

Than hald ni mag thera medun man gimakon fidan, though the sense is not quite parallel. If copied correctly it has lost its force here as in the AS., no by ær fram meahte (Beowulf, v. 754).

32. dinc ni geleitos; cf. Veldecke's Eneit, v. 77 ; teidinc leiden (v. Grienberger).

33. wuntane bouga : cf. Beowulf, vv. 1193, 3134 : wounden gold; Heliand, v. 554 : wundan gold.

34. cheisuringu, an imperial gold coin; cf. AS. casering: drachma, didrachma.

D. R. P. 
Hadubrant gima[ha]lta, Hiltibrantes sunu:

"Mit geru scal man geba infahan

ort widar orte. Du bist dir, alter Hun,

ummet spaher; spenis mih mit dinem wortun,

40 wili mih dinu speru werpan.

Pist also gialtet man, so du ewin inwit fuortos.

Đat sagetun mi sęolidante

westar ubar Wentilsęo, dat inan wic furnam.

Tot ist Hiltibrant, Heribrantes suno."

45 Hiltibrant gimahalta, Heribrantes suno:

"Wela gisihu ih in dinem hrustim, dat du habes heme herron goten, dat du no bi desemo riche reccheo ni wurti." "Welaga nu, waltant got (quad Hiltibrant), wewurt skihit.

50 Ih wallota sumaro enti wintro sehstic ur lante, dar man mih eo scerita in folc sceotantero, so man mir at burc eqnigeru banun ni gifasta. $\mathrm{Nu}$ scal mih suasat chind suertu hauwan, breton mit sinu billiu, eddo ih imo ti banin werdan.

55 Doh maht du nu aodlihho, ibu dir din ellen taoc in sus heremo man hrusti giwinnan rauba birahanen, ibu du dar enic reht habes. Der si doh nu argosto (quad Hiltibrant) ostarliuto, 36. MS. Hadubraht gimalta. 57. MS. bihrahanen.

45. MS. Hiltibraht.

37-8. There is perhaps a parallel to this passage in the Chronicon Novaliciense, 11r. 22, 23, where Algisus, when offered rings on the point of a spear, refuses to trust himself within reach of it, exclaiming: Si tu cum lancea ea mihi porrigis, et ego ea cum lancea excipio; cf. too Egilssaga, c. LV.

39. Cf. Heliand, v. 1376: spanan mid is spracu.

41. For the sequence of ideas, cf. piðriks saga, c. 400 (Bertelsen, II. 338): hann hxfir sig futt fram allan sinn aldr med sæmð oc drengskap oc sua er hann gamall orðinn.

42. Cf. Beowulf, v. 377 : pone sægdon pæt sæliðende.

43. Wentilsęo, "the Vandal Sea," "Mediterranean," a reminiscence of the days of Gaiseric (428-477), when the Vandal fleet terrorised the Mediterranean; of. AS. Wendelsæ in Elene, v. 231, Alfred's translation of Orosius, etc. pegnas.

dat inan wic furnam : cf. Beowulf, จ. 1080: wig ealle fornam Finnes

46 ff. Cf. Beowulf, v. $1484 \mathrm{ff}$.

48. I.e. "You have not lost your lord's favour." 
Hadubrand, the son of Hildebrand, replied: "With the spear should one receive a gift, point to point. Thou art of exceeding guile, old Hun. Thou seekest to decoy me with thy words and wilt aim thy spear at me. Thou hast grown old in the practice of treachery. Seafarers who went westwards over the Vandal Sea, have told me that he fell in battle. Dead is Hildebrand, the son of Heribrand."

Then spake Hildebrand, the son of Heribrand.

"By thy garb I see full well that thou hast a generous lord at home; thou art no outcast in this land."

"Woe now is me, Almighty God," quoth Hildebrand. "An evil fate is come upon me. Sixty summers and winters have I wandered in exile from my native land and I was ever stationed in the forefront of the host: yet no man dealt me my deathblow before any stronghold. But now mine own son will smite me with his sword, slay me with his brand, or I must be his slayer. Yet now if thy prowess avail thee, thou canst easily win the harness of so old a man, carry off the spoils, if thou hast any right to them. Now were he the craven of the easterners who

49. waltant got: cf. AS. wealdend god, OS. waldand god.

50. sehstic, i.e. 30 summers and 30 winters, a relic of the counting by seasons (misseri). It is worth noting that Wolf-Dietrich was likewise in exile for 30 years ; cf. Chadwick, Heroic Age, p. 155.

In pirriks saga, c. 396 (Bertelsen, II. 331), the exile lasted 32 jears.

51. sceotantero, simply "warriors"; cf. Beowulf, v. 1155, etc.

52. banun ni gifasta; of. Elene, v. 477 :

Ne meahton hie swa disige, deað oðfæstan.

53. suasat, "own"; of. AS. swæs, and Ásmundarsaga Kappabana, c. Ix.: Liggr bar inn svási sonr at höfði.

54. breton mit sinu billiu; wk vb, cf. AS. breodwian (Müllenhoff). For the phrase, cf. Exodus, v. 199: billum abreotan.

eddo ih imo ti banin werdan; cf. Heliand, v. 644 :

and Beowulf, จ. 587 : hogda im te banin uuerðon;

\section{beah đu binum brođrum to banan wurde.}

55. ibu dir din ellen taoc, a common phrase in the poetic diction of the old Teutonic languages; cf. Andreas, v. 460: gif his ellen deah, etc.

56. Cf. Waldhere, B 17.

57. ibu du dar enic reht habes, either "if you can make good your claim" or "if you have justice on your side."

58. ostarliuto, Huns rather than Ostrogoths; ef. Ásmundar saga, where Hildibrandr is styled Hanakappi. 
der dir nu wiges warne, nu dih es so wel lustit, 60 gudea gimeinun: niuse de motti, $[h]$ werdar sih hiutu dero hregilo rumen muotti, erdo desero brunnono bedero uualtan." Do lęttun se ærist asckim scritan, scarpen scurim, dat in dem sciltim stont.

65 Do stopun tosamane, †staimbort $\uparrow$ chlubun, heuwun harmlicco huitte scilti, unti im iro lintun luttilo wurtun, giwigan miti wabnum.......

61. MS. werdar sih dero hiutu, hrumen. 65. MS. stoptū, staim bort chludun.

59. $n u$ dih es so wel lustit; cf. Otfrid, I. 1. 14; so thih es uuola lustit.

60. gudea gimeinun; of. Beowulf, จ. 2473: wroht gemæne.

niuse de motti; cf. Heliand, จ. 224: he niate ef he môti ; Beowulf, จ. 1387 : wyrce se be mote.

61. Ms. werdar for hwedar (AS. hwæðer).

A parallel to this passage is to be found in pirriks saga, c. 19 (Bertelsen, $\mathbf{I}$. 19) : og bere sa $i$ brott hvarutveggia er meiri madur er og fræknare verdur $b a$ er reynt er (Kögel).

63. Klaeber, M. L. N. xxi. 110 ff., compares Layamon's Brut, vv. $28322 \mathrm{ff}$. :

Summe heo letten ut of scipen

Scerpe garen scripen,

and emends asckim to ascki; but the dat. is not absolutely impossible if taken in the sense of "let fly with spears." 
should refuse thee the combat, the duel, since thy heart is set upon it. Let him find out who can which of us this day is doomed to be stripped of his panoply or to win possession of both these corselets."

Then first they launched their spears, their sharp weapons, so that the shields were pierced. Then they strode together, they clove the...... bucklers shrewdly smiting at the white targets until their linden shields, destroyed by the weapons, were of none avail.

64. scarpen scurim (for scurun perhaps by analogy with asckim) in apposition to asckim; cf. Heliand, v. 5137 :

$$
\text { that man ina witnôdi wâpnes eggiun, }
$$

skarpun skurun,

where skûr is generally taken to mean "weapon" (Sievers, Z.f.d.Ph. xvI. 113); but cf. Beowulf, v. 1033 : scurheard, etc.

stont, impersonal, "so that there was a transfixing of the shields."

65. Most editors emend the Ms. stoptun to stopun; cf. Heliand, v. 4875: stop imu togegnes, and Rabenschlacht, v. 741 : zesamane si staphten.

Ms. staim bort chludun, regarded by Lachmann as a single compound noun, a kenning for "warriors." It is tempting, however, to emend chludun to chlubun on the analogy of Maldon, v. 283 : clufon cellod bord. The first element of staimbort has never been satisfactorily explained. The natural way would be to take it as "stone," hence " jewelled shields"; but I have not seen a single instance of shield-boss set with precious stones from grave-finds of the period, and the only literary evidence, Gregory of Tours' Historia Francorum, Ix. 28, is not perhaps very valuable, though for later times there is abundant evidence; cf. Nibelungenlied, str. 1640, 2149; Egilssaga, c. LxxvirI.

68. Cf. Maldon, v. 228 : forwegen mid his wæpne. 


\title{
GENERAL BIBLIOGRAPHY.
}

\author{
Modern Works.
}

Brandl, A. Cf. Pauls Grundriss(2).

Brooke, Stopford A. History of Early English Literature to the Accession of King Aelfred, 2 vols. London, 1892.

- English Literature from the Beginning to the Norman Conquest. London, 1898.

Chadwick, H. M. Early National Poetry (Camb. Hist. Eng. Lit. I. 19-40). Cambridge, 1907.

- The Origin of the English Nation. Cambridge, 1907. The Heroic Age. Cambridge, 1912.

Clarke, M. G. Sidelights on Teutonic History in the Migration Period. Cambridge, 1911.

Grimm, W. K. Deutsche Heldensage $(3)$. Gütersloh, 1889.

Gummere, F. B. Germanic Origins. New York, 1892.

Heinzel, R. Über die ostgotische Heldensagen. Wien, 1889.

Jiriczek, O. L. Deutsche Heldensagen, Bd I. Strassburg, 1898.

- Northern Hero-Legends (trans. M. B. Smith). London, 1902.

Ker, W. P. The Dark Ages. Edinburgh, 1904.

- Epic and Romance (2). London, 1908.

- English Literature; Medieval. London, 1912.

Kögel, R. Geschichte der deutschen Litteratur, I. 1. Strassburg, 1894.

Möller, H. Das altenglische Volksepos. Kiel, 1883.

Morley, H. English Writers, I.-II. (2) London, 1887-8.

Paul, H. Grundriss der Germanische Philologie ${ }_{(1)}$, Bd II. (especially Heldensage v. B. Symons; Gotische Lit. v. E. Sievers; Norwegischisländische Lit. v. E. Mogk; Althoch- u. altniederdentsche Lit. v. R. Kögel; Mhd. Lit. v. F. Vogt; Altenglische Lit. v. B. ten Brink; Altgermanische Metrik v. E. Sievers). Strassburg, 1891-3.

- Grundriss(2), Bd III. (especially Gotische Lit. v. W. Streitberg; Ahd. u. and. Lit. v. R. Kögel u. W. Brückner; Mhd. Lit. v. F. Vogt; Norwegisch-isländische Lit. v. E. Mogk; Englische Lit. v. A. Brandl; Heldensage v. B. Symons). Strassburg, 1896-1909.

Stjerna, K. M. Essays on questions connected with the Old English poem of Beowulf (Viking Club Series). Coventry, 1912. 
ten Brink, B. Early English Literature. London, 1883.

Geschichte der englischen Literatur, hrsg. v. A. Brandl, Bd I. Strassburg, 1899.

Wülker, R. P. Grundriss der Geschichte der angelsächsischen Literatur, Bd II. Leipzig, 1885.

Geschichte der englischen Literatur. Leipzig, 1896.

Zeuss, J. C. Die Deutschen und die Nachbarstämme. München, 1837 (facsimile reprint, Göttingen, 1904).

\section{Gothic.}

Feist, S. Etymologische Wörterbuch der gotische Sprache. Halle, 1909. Streitberg, W. Die Gotische Bibel. Heidelberg, 1908-10.

Jantzen, H. Gotische Sprachdenkmäler $(3)$ (Samml. Göschen). Leipzig, 1909.

Bernhardt, E. Die gotische Bibel des Vulfila. Halle, 1884.

Holder, A. Jordanis de Origine Actibusque Getarum. Freiburg i. B. u. Tübingen, 1882.

Mommsen, Th. Jordanis Romana et Getica (M.G.H. Auctores Antiquissimi, v. 1). Berlin, 1882.

tr. C. C. Mierow. The Gothic History of Jordanes. Princeton, 1915.

$$
\text { Anglo-Saxon. }
$$

Bosworth, J.-Toller, T. N. Anglo-Saxon Dictionary. Oxford, 1898.

Toller, T. N. Supplement, A-eor $b$. Oxford, 1908.

Grein, C. W. M. Sprachschatz der angelsächsischen Dichter: Neuausgabe von Holthausen-Kohler. Heidelberg, 1912.

Sweet, H. Anglo-Saxon Reader (8) . Oxford, 1908.

- Second Anglo-Saxon Reader. Oxford, 1887.

Kluge, F. Angelsächsisches Lesebuch $(3)$. Halle, 1902.

tr. A. S. Cook and C. B. Tinker. Select Translations from old English Poetry. Boston, 1902.

- Select Translations from Old English Prose. Boston, 1908.

Grein-Wülker. Bibliothek der angelsächsischen Poesie ${ }_{(2)}, 3$ vols. Kassel and Leipzig, 1881-98.

Sedgefield, W. J. $\quad$ Beowulf $_{(2)}$. Manchester, 1913.

Wyatt, A. J. and Chambers, R. W. Beowulf with the Finnsburg Fragment. Cambridge, 1914.

Heyne, M.-Schücking, L. L. Beowulf $f_{(9)}$. Paderborn, 1910.

Zupitza, J. Beowulf: Autotypes of the Cotton MS. with transliteration and notes (E.E.T.S. 77). London, 1882.

tr. C. G. Child. Beowulf and the Finnesburh Fragment. London, 1904.

J. R. Clark Hall. Beownulf and the Finnesburg Fragment $(2)$. London, 1911. 
Thorpe, B. Codex Exoniensis. London, 1842.

Gollancz, I. The Poems of the Exeter Book (with translations), Vol. I. (E.E.T.S. 102). London, 1892.

Chambers, R. W. Widsith. Cambridge, 1912.

Gollancz, I. Cynewulf's Christ (with translation). London, 1892.

Cook, A. S. The Christ of Cynewulf. Boston, 1900.

Kent, C. W. Elene $(2)$. Boston, 1902.

Holthausen, F. Cynewulf's Elene $(2)$. Heidelberg, 1910.

Krapp, G. P. Andreas and the Fates of the Apostles. Boston, 1906.

Strunk, W. jun. Juliana. Boston, 1904.

tr. C. W. Kent. The Poems of Cynewulf. London, 1910.

Tupper, F. The Riddles of the Exeter Book. Boston, 1910.

Wyatt, A. J. Old English Riddles. Boston, 1913.

Kemble, J. M. Codex Vercellensis, 2 vols. London, 1843.

Wülker, R. P. Codex Vercellensis. Leipzig, 1894.

Förster, M. Il Codice Vercellese con Omelie e Poesie in Lingua Anglosassone, riprodotto in fototipia. Roma, 1913.

Holthausen, F. Die alltere Genesis. Heidelberg, 1914.

Klaeber, F. The Later Genesis and other OE. and OS. texts relating to the Fall of Man. Heidelberg, 1913.

Blackburn, F. A. Exodus and Daniel. Boston, 1907.

Cook, A. S. The Dream of the Rood. Oxford, 1905.

- Judith. Boston, 1904.

Sedgefield, W. J. The Battle of Maldon and Poems from the AngloSaxon Chronicle. Boston, 1904.

Grein, C. W. M. Bibliothek der ags. Prosa, Bd I.-vIr. Kassel, Göttingen, Hamburg, 1872-1910.

Sweet, H. The Oldest English Texts (E.E.T.S. 83). London, 1885.

- The Anglo-Saxon Version of Gregory's Pastoral Care (E.E.T.S. 45, 50). London, 1871-2.

King Alfred's Orosius (E.E.T.S. 79). London, 1883.

Sedgefield, W. J. King Alfred's Translation of Boethius. Oxford, 1899.

- tr. King Alfred's Version of the Consolations of Boethius. Oxford, 1900.

Plummer, C. Boedae Opera Historica, 2 vols. Oxford, 1896.

tr. A. M. Sellar. Beda: Ecclesiastical History of England $(2)$. London, 1912.

Earle, J. and Plummer, C. Two Saxon Chronicles Parallel, 2 vols. Oxford, 1892-9.

tr. E. E. C. Gomme. The Anglo-Saxon Chronicle. London, 1909.

Herzfeld, G. OE. Martyrology (E.E.T.S. 116). London, 1900.

Thorpe, B. The Homilies of Alfric (Elfric Soc.). London, 1844-6.

Napier, A. S. Wulfstan. Berlin, 1883.

- OE. Glosses (Anecdota Oxon.). Oxford, 1900. 
Wright, T. and Wiilker, R. P. Anglo-Saxon and Old English Vocabularies. London, 1884.

Stevenson, J. Rituale Ecclesiae Dunelmensis (Surtees Soc. 10). 1839. and Waring, G. Lindisfarne and Rushworth Gospels (Surtees Soc. $28,39,43,48)$. 1854-65.

Cockayne, O. Leechdoms, Wortcunning and Starcraft of Early England (Rolls Series), 3 vols. London, 1864-6.

Kemble, J. M. Codex Diplomaticus Anglo-Saxonici Aevi, 6 vols. London, 1839-48.

Thorpe, B. Diplomatarium Anglicum Saxonici Aevi. London, 1865.

Birch, W. de G. Cartularium Saxonicum, 4 vols. London, 1883-93.

\section{German.}

Schade, O. Altdeutsches Wörterbuch (2). Halle, 1882.

Müllenhoff, K. u. Scherer, W. Denkmäler deutscher Poesie u. Prosa aus den vIII.-XIr. Jahrh.(3) Berlin, 1892.

Eneccerus, M. Die ältesten deutschen Sprachdenkmäler in Lichtdrücken. Frankfurt a. M., 1897.

Braune, W. Althochdeutsche Lesebuch $(7)$. Halle, 1911.

Steinmeyer, E. u. Sievers, E. Die Althochdeutsche Glossen, Bd IV. Berlin, 1879-98.

Sievers, E. Tatian, lateinisch und altdeutsch $_{(2)}$. Paderborn, 1892.

Piper, P. Die Schriften Notkers und seine Schule, Bd III. Freiburg, 1882-3.

— Otfrieds Evangelienbuch $(2)$, Bd II. Freiburg, 1882-7.

Heyne, M. Héliand nebst den Bruchstücken der altsächs. Genesis $(4)$. Paderborn, 1905.

— Kleinere altniederdeutsche Denkmäler $(2)$. Paderborn, 1877.

Gallée, J. H. Altsächsische Sprachdenkmäler. Leiden, 1894.

Lachmann, K. Der Nibelunge Noth und die Klage ${ }_{(13)}$. Berlin, 1910.

tr. M. Armour. The Fall of the Nibelungs (Everyman). London, 1908.

Martin, E. Kudrun. Halle, 1872.

tr. M. P. Nichols. Gudrun. Boston, 1889.

Kinzel, K. Lamprechts Alexander. Halle, 1884.

Deutsche Heldenbuch, Bd v. Berlin, 1866-75.

I. Jänicke, O. Biterolf u. Dietlieb, Laurin u. Walberan (1866).

II. Martin, E. Alpharts Tod, Dietrichs Flucht, Rabenslacht (1866). III.-IV. Amelung, A. u. Jänicke, O. Ortnit $u$. die Wolfdietriche (1871-5).

V. Zupitza, J. Dietrichs Abenteuer (1870).

\section{Scandinavian.}

Cleasby, R. and Vigfússon, G. Old Icelandic Dictionary. Oxford, 1879. 
Egilsson, S. Lexicon Poëticum antiquae Linguae Septentrionalis. Havniae, 1860.

Of the new edition, revised by Finnur Jonsson for the Konglige Nordiske Oldskriftselskab, A-lymskufljotr has appeared. København, 1913-.

Fritzner, J. Ordbog over det gamle norske Sprog, Bd III. Kristiania, 1886-96.

Die Lieder der älteren $E d d a_{(2)}$, hrsg. v. Hildebrand-Gering. Paderborn, 1904.

Særmundar Edda, F. Jónsson bj6 til prentunar. Reykjavik, 1905.

tr. B. Thorpe. Edda Sæmundar hinns Fróð 2 , 2 vols. London, 1866.

O. Bray. The Elder or Poetic Edda, part I. (Viking Club Series). Coventry, 1908.

Corpus Poeticum Boreale, ed. G. Vigfússon and F. York Powell. Oxford, 1883.

Edda Snorra Sturlasonar sumptibus legati Arnamagnæani, t. III. Havniae, 1848-87.

— F. Jónsson bjó til prentunar. Reykjavík, 1907.

tr. G. W. Dasent. The Prose or Younger Edda (omitting Skaldskaparmál). Stockholm, 1842.

R. B. Anderson. The Younger Edda. Chicago, 1880.

Origines Islandicae, ed. Vigfússon and Powell. Oxford, 1905.

Islendinga Sögur bair hefir til prentunar V. Ásmundarson, 37 vols. Reykjavík, 1891-1902.

Altnordische Sagabibliothek, hrsg. v. G. Cederschiöld, H. Gering u. E. Mogk, 13 vols. Halle, 1892-.

tr. G. W. Dasent. The Story of Burnt-Njal, 2 vols. Edinburgh, 1861. (Several times reprinted in one volume.)

- The Story of Gisli the Outlaw. Edinburgh, 1866.

E. Head. The Story of Viga-Glum. London, 1866.

E. Magnússon and W. Morris. The Story of Grettir the Strong. London, 1869.

— Three Northern Love Stories. London, 1875.

— The Saga Library, vols. I.-II. London, 1891-2.

G. A. Hight. The Grettir Saga (Everyman). London, 1913.

W. C. Green. The Story of Egil Skallagrimsson. London, 1893.

M. A. C. Press. The Laxdæla Saga. London, 1899.

Heimskringla, udgivet af F. Jónsson, 4 vols. København, 1893-1901.

— udgivet af F. J., l vol. København, 1911.

tr. Morris and Magnússon. The Saga Library, vols. III.-VI. London, 1893-1905.

Flateyjarbók, udg. G. Vigfússon og C. R. Unger, 3 vols. København, $1860-8$.

tr. J. Sephton, The Saga of King Olaf Tryggwason. London, 1895. 40 Islendingar pættir, p. Jónsson gaf út. Reykjavik, 1904. 


\section{General Bibliography}

Fornmanna Sögur, 12 vols. Kjøbenhavn, 1825-37.

Fornaldarsögur Norðrlanda, búið hefir til prentunar V. Ásmundarson, 3 vols. Reykjavik, 1885-9.

tr. Morris and Magnússon. Völsunga Saga. London, 1870.

Skjöldunga Saga, ed. A. Olrik (from Aarb. f. n. O. 1894). Kjøbenharn, 1894.

Saxo Grammaticus. Historia Danica, ed. A. Holder. Strassburg, 1885. tr. O. Elton. The Fir'st Nine Books of Saxo. London, 1892.

pirriks saga af Bern, ed. H. Bertelsen, 2 vols. København, 1905-11. 


\section{INDEX OF NAMES}

MENTIONED IN THE POEMS

Wa, $\mathrm{Wb}=$ Waldhere $\mathrm{A}$ and $\mathrm{B} . \quad \mathrm{AS}, \mathrm{N}, \mathrm{I}=$ Anglo-Saxon, Norwegian and Icelandic Runic Poems. $F=$ Finn. $\mathrm{D}=$ Deor. $\mathrm{H}=$ Hildebrand.

政lfhere (Wa. 11, b. 18), 37-43, 56, $57,60,61$

无tla (Wa. 6), 38-41, 48, 56, 57

Asgarðr (I. 4), 28, 29

Beadohild (D. 8), 46, 70, 72, 73

Burgendas (Wb. 14), 41, 60, 61

Deor (D. 37), 45, 46, 76, 77

Eaha (F. 17), 66, 67

East-Dene (AS. 67), 20, 21

Eormanric (D. 21), 46, 74, 75

Fárbauti (I. 16), 32, 33

Finn (F. 38), 43-45, 64-69

Fróðe (N. 10), 26, 27

Garulf (F. 20, 23), 66-69

Gautr (I. 4), 28, 29

Geat (D. 15), 45, 72, 73

Gotan (D. 23), 74, 75

Guðere 1 (F. 20), 66, 67

Gưhere 2 (Wa. 25), 38-41, 58-61

Guplaf 1 (F. 18), 44, 66, 67

Guðlaf 2 (F. 35), 68, 69

Hadubrand (H. 3, 14, 17, 36), 48, $78,78-83$

Hagena (Wb. 15), 38-41, 60, 61, 76

Heardingas (AS. 70), 20, 21

Hengest (F. 19), 44, 45, 64, 66, 67

Heodeningas (D. 36), 76-77

Heorrenda (D. 39), 76-77

Heribrand (H. 7, 44, 45), 78, 79, 82-83
Hildebrand (H. 3, 7, 14, 17, 30, 36, $44,45,49,58), 46-49,78-85$

*Hildegyth, 37-43, 56-59

Hun (H. 35, 38), 37-41, 80, 82, 83 Ing (AS. 67), 20, 21

Jupiter (I. 4), 28

Kristr (N. 7), 24, 25

Loki (N. 13), 26, 27

Mæringas (D. 19), 74, 75

Mæßhild (D. 14), 45, 72, 73

Mars (I. 12), 30

Mimming (Wa. 3), 56, 57, 60, 70

Niðhad (Wb. 8, D. 4), 45, 60, 61, 70-73

Ordlaf (F. 18), 44, 66, 67

Otacher (H. 18, 25), 75, 80, 81

Reginn (N. 5), 24, 25

Saturnus (I. 3), 28, 29

Secgan (F. 26), 66, 67

Sigefer $ð$ (F. 17, 26), 66, 67

peodric (Wb. 4, D. 18, H. 19 , Theotrihhe; 23, Detrihhe; 26, Deotrichhe), 45, 46, 48, 74, 75

Týr (N. 12, I. 12), 18, 26, 27, 30, 31

Valholl (I. 4), 28, 29

Varơrún (I. 3), 28, 29

Waldhere (Wb. 11), 37-43, 56-63

Weland (Wa. 2, b. 9, D. 1), 46, $56,57,60,61,70-73$

Wentilsęo (H. 43), 82, 83

Widia (Wb. 4, 9), 60, 61, 70-73 


\section{SELECTION FROM THE GENERAL CATALOGUE OF BOOKS PUBLISHED BY THE CAMBRIDGE UNIVERSITY PRESS}

The Heroic Age. By H. MunRo Chadwick, Professor of Anglo-Saxon in the University of Cambridge. With 3 maps. Demy 8vo. 12s. net.

The Origin of the English Nation. By H. MUNRo CHADWICK, M.A. With 4 maps. Demy 8vo. 7s. 6 d. net.

Studies on Anglo-Saxon Institutions. By H. MUNRO CHADWICK, M.A., Professor of Anglo-Saxon in the University of Cambridge. Crown 8vo. 8s. net.

Widsith. A Study in Old English Heroic Legend. By R. W. Chambers, M.A. Demy 8vo. Ios. net.

Beowulf, with the Finnsburg Fragment. Edited by A. J. WyatT. New edition, revised, with introduction and notes, by R. W. Chambers. With 2 facsimiles of MSS. Demy 8 vo. 9s. net.

Beowulf. A metrical translation into Modern English. By John R. Clark Hall. Crown 8vo. 2s. $6 d$. net.

Outlines of the History of the English Language. By T. N. Toller, M.A. Crown 8 vo. 4 s.

English Dialects from the Eighth Century to the Present Day. By W. W. SkEAT, Litt.D. With Facsimile. Cloth, Is. net; leather, $2 s .6 d$. net. Cambridge Manuals Series.

An Elementary Old English Grammar (Early WestSaxon). By A. J. Wyatr, M.A. Crown 8vo. 4s. $6 d$.

An Elementary Old English Reader (Early WestSaxon). By A. J. WyatT, M.A. Crown 8vo. 4s. $6 d$.

The Icelandic Sagas. By W. A. CRAIGIE, LL.D. With 2 illustrations and a map. Cloth, Is. net; leather, 2s. $6 d$. net. Cambridge Manuals Series.

The Cult of Othin. An Essay in the Ancient Religion of the North. By H. M. CHADWICK, M.A., Professor of AngloSaxon in the University of Cambridge. Crown 8vo. 2s. $6 d$.

The Vikings. By Allen Mawer, M.A. With 4 illustrations. Cloth, Is. net; leather, $2 s .6 d$. net. Cambridge Manuals Series.

The Thunderweapon in Religion and Folklore. A study in comparative archaeology. By CHR. BLINKENBERG, Ph.D. With 36 illustrations and map. Demy 8vo. 5 s. net. 


\title{
CAMBRIDGE HISTORY \\ OF
}

\section{ENGLISH LITERATURE}

\author{
EDITED BY \\ SIR A. W. WARD, Litt.D., F.B.A., \\ MASTER OF PETERHOUSE
}

AND

\section{A. R. WALLER, M.A., \\ PETER HOUSE}

In fourteen royal $8 \mathrm{vo}$. volumes. Volumes I-I2 are now ready.

I. From the Beginnings to the Cycles of Romance.

2. THE END OF THE MidDle Ages.

3. RENASCENCE AND REFORMATION.

4. Prose and Poetry, Sir Thomas NORTH TO MICHAELDRAYTON.

5, 6. The Drama TO 1642 .

7. Cavalier and Puritan.

8. THE AGE OF DRYDEN.

Price, in cloth gs. net, in half-morocco 15 s. net, each volume.

Subscription price for the complete work $£ 5.5 \mathrm{~s}$. od. net in cloth, 68. 15 s. od. net in half-morocco, payable in fourteen instalments of $75.6 d$. net or $12 s .6 d$. net respectively, on publication of the separate volumes.

Two additional volumes will be published which will contain extracts in prose and verse illustrative of the text of the History, in addition to about 100 reproductions of title-pages, portraits, facsimiles, or other illustrations. The published price of these volumes will be ros. net each, but subscribers to the History will have the privilege of purchasing them at $75.6 d$. net each.

The Contemporary Review. It is scholarly, thorough, accurate and well balanced....The work is admirable. The bibliographies are a treasure house. The descriptions of successive literary movements, both primary and secondary, with the human forces, great and less great, English and foreign, that played their part in such movements, are all of high and often noble merit.

The Saturday Review. This rich composite history of English literature is a real service to English scholarship. It presents us with the first adequate treatment of many neglected parts of our literary history, and it throws new light on many old themes.... The editors deserve all thanks, and the critic who feels inclined to quarrel with this point or that in their methods or conclusions will be humiliated and silenced when he remembers that this is the first attempt by a body of scholars to tell the story of our literature on a scale worthy of its greatness.

Cambridge University Press

C. F. Clay, Manager

London: Fetter Lane, E.C.

Edinburgh : 100, Princes Street 




\title{
PN Dickins, Bruce \\ 839 Runic and herbic poems of \\ D53 the old Teutonic peoples
}

\author{
PLEASE DO NOT REMOVE \\ CARDS OR SLIPS FROM THIS POCKET
}

UNIVERSITY OF TORONTO LIBRARY 
